\title{
ANÁLISE DOS PROTEOMAS EXTRACELULARES E DO ACÚMULO DE MOLÉCULAS SINAIS DURANTE $O$ CRESCIMENTO DE Xylella fastidiosa 9a5c in vitro
}

\author{
Denise Santos da Silva
}

Tese apresentada à Escola Superior de Agricultura "Luiz de Queiroz", Universidade de São Paulo, para obtenção do título de Doutor em Agronomia, Área de Concentração: Microbiologia Agrícola.

PIRACICABA

Estado de São Paulo - Brasil

Janeiro - 2004 


\title{
ANÁLISE DOS PROTEOMAS EXTRACELULARES E DO ACÚMULO DE MOLÉCULAS SINAIS DURANTE $O$ CRESCIMENTO DE Xylella fastidiosa 9a5c in vitro
}

\author{
Denise Santos da Silva \\ Engenheiro Agrônomo
}

Orientador: Prof. Dr. MARCIO RODRIGUES LAMBAIS

\begin{abstract}
Tese apresentada à Escola Superior de Agricultura "Luiz de Queiroz", Universidade de São Paulo, para obtenção do título de Doutor em Agronomia, Área de Concentração: Microbiologia Agrícola.
\end{abstract}

PIRACICABA

Estado de São Paulo - Brasil

Janeiro - 2004 
Dados Internacionais de Catalogação na Publicação (CIP) DIVISÃO DE BIBLIOTECA E DOCUMENTAÇÃO - ESALQ/USP

Silva, Denise Santos da

Análise dos proteomas extracelulares e do acúmulo de moléculas sinais durante o crescimento de Xylella fastidiosa 9a5c in vitro / Denise Santos da Silva. - - Piracicaba, 2004.

93 p. : il

Tese (doutorado) - Escola Superior de Agricultura Luiz de Queiroz, 2004.

Bibliografia.

1. Bacterias fitopatogênicas 2. Clorose variegada dos citros 3. Crescimento "in vitro" 4. Eletroforese em gel 5. Insetos vetores 6. Proteínas I. Título

CDD 632.32

\section{"Permitida a cópia total ou parcial deste documento, desde que citada a fonte - $\mathrm{O}$ autor"}


À meus pais, Vilson e Nilsen, e meus irmãos Dedico! 
"A imaginação é a mais alta prerrogativa do ser humano" 


\section{AGRADECIMENTOS}

À presença divina que ilumina nossos caminhos;

Ao Prof. Dr. Marcio Rodrigues Lambais pela orientação, amizade, estímulo, experiência e otimismo constante;

À FAPESP, pela bolsa de estudos e auxilio financeiro para o projeto;

Ao Eduardo, pelo convívio, companheirismo, carinho, afeto e ajuda inestimáveis ;

À Profa. Dra. Neusa Nogueira, por seu apoio e amizade, os quais foram de fundamental importância no início do doutorado;

Aos amigos do Laboratório, Adriana, Adrianinha, Dani, Daniela, Juliano, Magneto, Pamoñero, Robinson, Suzel, $\pi$ Bull, pelos momentos de descontração e de trabalho. Em especial ao Simão, pela boa vontade, paciência e pelos ensinamentos na análise de proteínas;

Às companheiras do Projeto Genoma Funcional da Xylella, Leandra e Beatriz, pela amizade, companheirismo e troca de experiências ;

À Beth, pela constante presença, estímulo e amizade;

À todos os amigos que estiveram presentes, pelo incentivo e carinho e, àqueles que ficaram ausentes pela distância mas presentes nas vibrações;

Aos técnicos do Laboratório de Microbiologia do Solo, Denise Mescholotti e Fernando Baldesin, pela auxílio e amizade inestimáveis; 
Aos funcionários do departamento de solos, com gratidão especial à Martinha; À Profa. Dra. Helaine Carrer, Profa. Dra. Marli de Fiore e Prof. Dr. Flávio Tavares, pelas sugestões no Exame de Qualificação;

Muito Obrigado! 


\section{SUMÁRIO}

Página

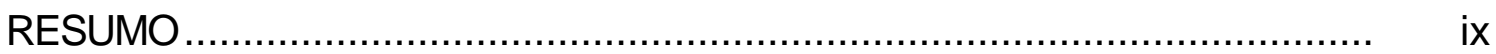

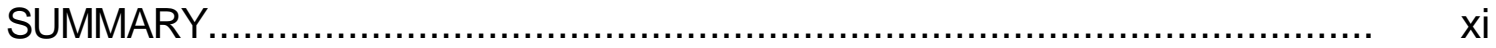

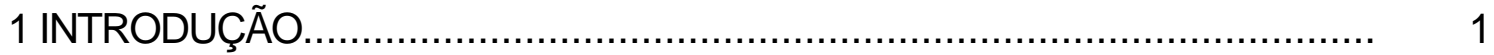

2 REVISÃO DE LITERATURA .............................................................. 5

2.1 Clorose variegada dos citros (CVC) ................................................. 5

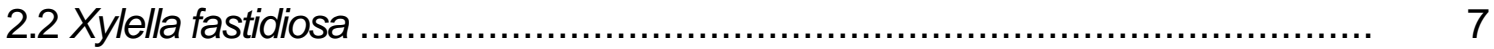

2.3 Regulação das interações $X$. fastidiosa - planta.......................................... 9

2.4 Mecanismos de patogenicidade e/ou virulência......................................... 13

2.4.1 Secreção de fatores de patogenicidade/virulência em bactérias ................. 14

2.4.2 Percepção de quorum em bactérias fitopatogênicas ............................... 18

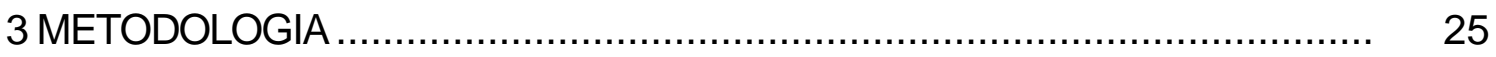

3.1 Crescimento da X. fastidiosa em meio PW modificado............................... 25

3.2 Extração de proteínas extracelulares produzidas por $X$. fastidiosa .................. 27

3.3 Análises moleculares da $X$. fastidiosa utilizada nos experimentos ......... 28

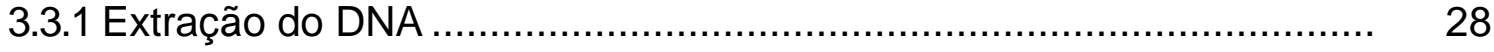

3.3.2 Amplificação de fragmento diagnóstico da X. fastidiosa ...................... 28

3.4 Eletroforese bidimensional (2D-PAGE) de proteínas extracelulares de

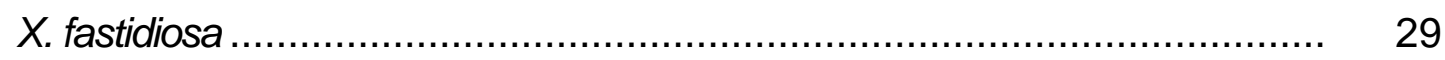

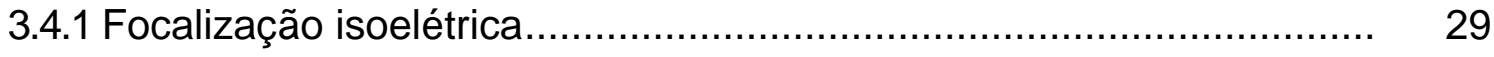

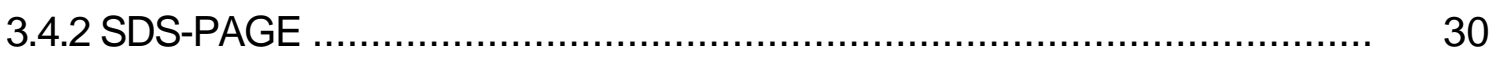

3.4.3 Detecção das proteínas por impregnação com prata ......................... 30

3.4.4 Aquisição das imagens e análise dos dados ................................... 31 
3.5 Bioensaios para detecção de moléculas sinais difusíveis ........................ 32

3.5.1 Bioensaio para detecção de lactonas de homoserina aciladas ............ 32

3.5.2 Bioensaio para detecção de DSF ........................................ 33

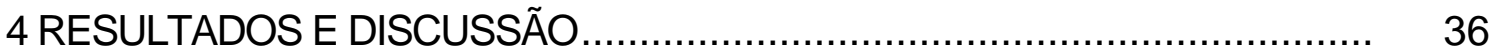

4.2 Confirmação da identidade do isolado utilizado nos experimentos .............. 36

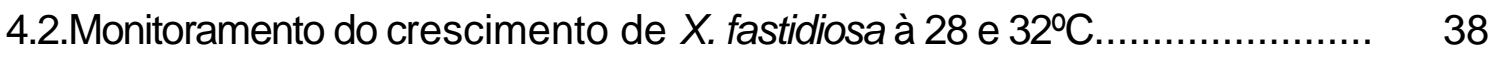

4.3 Análise do proteoma extracelular de X. fastidiosa cultivada em meio PW modificado líquido............................................................... 46

4.4 Bioensaios para detecção de moléculas sinais difusíveis ........................ 69

4.4.1 Bioensaio para detecção de lactonas de homoserina aciladas

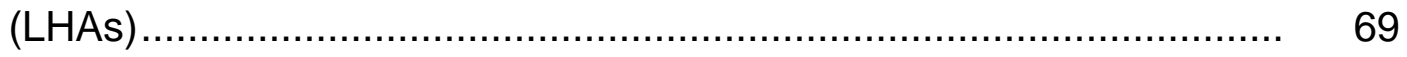

4.4.2 Bioensaio para detecção de DSF ...................................... 70

4.4.3 Caracterização parcial do DSF ................................................. 76

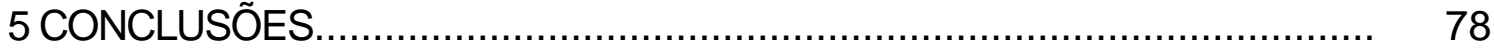

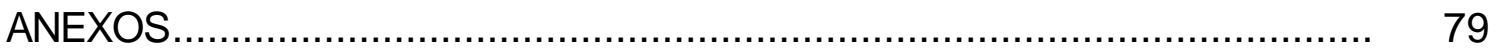

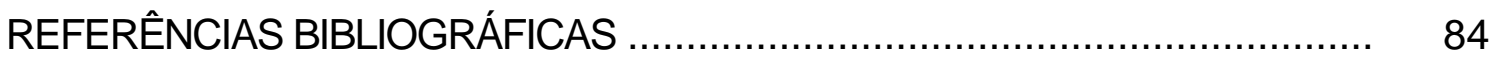




\title{
ANÁLISE DOS PROTEOMAS EXTRACELULARES E DO ACÚMULO DE MOLÉCULAS SINAIS DURANTE O CRESCIMENTO DA
}

\author{
Xylella fastidiosa 9a5c in vitro
}

\begin{abstract}
Autor: DENISE SANTOS DA SILVA
Orientador: Prof. Dr. MARCIO RODRIGUES LAMBAIS
\end{abstract}

RESUMO

A bactéria Xylella fastidiosa 9a5c é o agente causal da clorose variegada dos citros (CVC) e responsável por grandes perdas econômicas na citricultura. O genoma de $X$. fastidiosa 9a5c foi totalmente seqüenciado e a sua análise permitiu identificar vários genes possivelmente envolvidos na patogenicidade/virulência da bactéria. Como os sintomas da CVC desenvolvemse um longo tempo após a infecção da planta pela bactéria e a severidade da doença têm sido associada à altas temperaturas, é possível que a expressão de fatores de patogenicidade/virulência seja dependente de densidade celular e/ou estresses térmicos. Desta forma, o crescimento in vitro da $X$. fastidiosa foi monitorado através da absorbância de suspensões bacterianas à $600 \mathrm{~nm}\left(\mathrm{~A}_{600}\right)$, número de unidades formadoras de colônias (UFC) e viabilidade celular, durante 16 dias de cultivo em meio PW modificado líquido, à 28 e $32^{\circ} \mathrm{C}$. Proteínas extracelulares foram extraídas e analisadas através da eletroforese bidimensional em gel de poliacrilamida (2D-PAGE). Bioensaios foram utilizados para verificar a produção de moléculas sinais por $X$. fastidiosa. Os resultados obtidos mostraram que o crescimento de $X$. fastidiosa à $32^{\circ} \mathrm{C}$, com base na $\mathrm{A}_{600}$, não diferiu do crescimento à $28^{\circ} \mathrm{C}$. No entanto, com base no número de 
UFCs e viabilidade celular, o crescimento de $X$. fastidiosa diferiu em função da temperatura, tempos de incubação e a interação entre esses fatores. X. fastidiosa produziu maior número de proteínas extracelulares à 32 do que à $28^{\circ} \mathrm{C}$, mostrando que a secreção de proteínas em $X$. fastidiosa é regulada pela temperatura de incubação. Várias proteínas extracelulares produzidas por $X$. fastidiosa à 28 e $32^{\circ} \mathrm{C}$ são moduladas durante o crescimento da bactéria. $\mathrm{A}$ maior parte das proteínas extracelulares produzidas por $X$. fastidiosa são proteínas ácidas e de massa molecular aparente entre 20-60 kDa. X. fastidiosa não sintetizou moléculas de lactonas de homoserina aciladas (LHAs) reconhecidas pelo sistema repórter utilizado, mas sintetizou uma molécula extracelular em meio de cultivo, semelhante ao DSF produzido por $X$. campestris pv. campestris, capaz de restaurar a atividade da endoglucanase através do sistema repórter utilizado. A concentração desta molécula em meio PW modificado foi dependente da densidade de células de $X$. fastidiosa no meio. 


\title{
ANALYSES OF THE EXTRACELLULAR PROTEOMES AND ACCUMULATION OF SIGNAL MOLECULES DURING Xylella fastidiosa 9a5c GROWTH in vitro
}

\author{
Author: DENISE SANTOS DA SILVA \\ Adviser: Prof. Dr. MARCIO RODRIGUES LAMBAIS
}

\section{SUMMARY}

The bacterium Xylella fastidiosa is the causal agent of the citrus variegated chlorosis (CVC) and is responsible for significant economic losses in citriculture. The genome of $X$. fastidiosa has been completely sequenced and revealed several genes probably involved in pathogenicity/virulence. Since CVC symptoms are develop a long time after infection of plant by the bacterium and the severity of the disease has been associated with high temperatures, it's possible that the expression of pathogenicity/virulence factors is dependent on cellular density and/or temperature stresses. Thus, the growth of $X$. fastidiosa in modified liquid PW medium was measured based on the absorbance of suspensions at $\left(A_{600}\right)$, number of colony-forming units (CFU) and cellular viability, during 16 days at 28 and $32^{\circ} \mathrm{C}$. Extracellular proteins were extracted and analysed by two-dimensional gel electrophoresis (2D-PAGE). Bioassays were used to determine whether $X$. fastidiosa produces signal molecules involved in quorum perception. The results showed that temperatures of 28 and $32^{\circ} \mathrm{C}$ did not affect the growth of the bacterium, based on $A_{600}$. Temperatures of 28 and $32^{\circ} \mathrm{C}$, incubation times and the interaction of both factors affected bacterial growth based on CFU numbers and the cellular viability. $X$. fastidiosa produced higher number of extracellular proteins at 32 than at $28^{\circ} \mathrm{C}$, showing that protein secretion is dependent on growth 
temperature. Several extracellular proteins produced by $X$. fastidiosa at 28 and $32^{\circ} \mathrm{C}$ were modulated the bacterial growth. Most of the extracellular proteins produced by $X$. fastidiosa were acidic with apparent molecular mass within 20-60 kDa. X. fastidiosa did not synthesize $\mathrm{N}$-acyl homoserine lactone $(\mathrm{AHL})$ recognizes by the reporter system used. However, it synthesized an extracellular molecule in modified PW medium, similar to DSF produced by $X$. campestris pv. campestris, which is able to restore endoglucanase activity by the reporter system. The concentration of this extracellular molecule produced by $X$. fastidiosa was dependent on cellular density. 


\section{INTRODUÇÃO}

$\mathrm{Na}$ citricultura brasileira e mundial, a laranja doce [Citros sinensis (L) Osbeck] é a espécie que apresenta maior importância sócio-econômica. O Brasil é um dos maiores produtores mundiais de laranjas e o Estado de São Paulo é responsável por $80 \%$ desta produção (Abecitros, 1999).

Atualmente, uma das grandes preocupações dos citricultores é a clorose variegada dos citros (CVC), doença identificada oficialmente no Brasil em 1987, em pomares do Triângulo Mineiro e do Norte e Noroeste do Estado de São Paulo. Essa ainda é a região mais afetada, muito embora a bactéria esteja presente na maioria das áreas citrícolas do país (Donadio \& Moreira, 1997).

A rápida disseminação da CVC pelos pomares brasileiros e o alto nível de dano causado por esta doença tem resultado em grandes perdas econômicas no cultivo de plantas cítricas e para a indústria de suco de laranja (Coletta-Filho \& Machado, 2002).

A CVC é causada por Xylella fastidiosa, uma bactéria gram-negativa, restrita ao xilema da planta, a qual bloqueia os vasos do xilema, obstruindo a passagem de nutrientes e água. A $X$. fastidiosa é transmitida e disseminada nos pomares através de insetos vetores (cigarrinhas). Os sintomas da doença surgem como uma clorose nas folhas maduras da copa, progredindo para lesões circulares na folhas, às vezes necrosadas. Com o agravamento da doença, os frutos tornam-se queimados pelo sol, com tamanho reduzido, endurecidos, apresentando amarelecimento precoce e tornando-se imprestáveis para a comercialização (Fundecitrus, 1997). 
Algumas hipóteses sobre os mecanismos de patogenicidade de $X$. fastidiosa, envolvendo a síntese de fitotoxina (Lee et al., 1982), desequilíbrio hormonal (French \& Stassi, 1978) e disfunção do xilema (Hayward \& Mariano, 1997), têm sido propostas. Entretanto, nenhuma delas é conclusiva.

$O$ seqüenciamento do genoma de $X$. fastidiosa 9a5c, causadora da CVC, permitiu a formulação de hipóteses mais elaboradas sobre os mecanismos de patogenicidade/virulência dessa bactéria, tais como a produção de toxinas, secreção de enzimas capazes de degradar a parede celular vegetal, seqüestro de íons e formação de biofilme (Dow \& Daniels, 2000; Keen et al., 2000; Lambais et al., 2000; Simpson et al., 2000; Silva et al., 2002).

Em algumas bactérias, a produção de fatores de patogenicidade/virulência é regulada por mecanismos de percepção de quorum envolvendo moléculas de lactonas de homoserina aciladas (LHAs) e outras moléculas sinais solúveis (Jones et al., 1993; Barras et al., 1994). LHAs são sintetizadas no citoplasma bacteriano e se difundem através da membrana plasmática, acumulando-se no meio externo durante o crescimento da bactéria. A percepção de LHAs pelas bactérias é parte de um mecanismo complexo de monitoramento das mudanças do meio e de respostas cooperativas (Fuqua et al., 1996).

Em Erwinia carotovora, uma bactéria causadora de podridão em várias plantas, a patogenicidade é dependente da produção de enzimas extracelulares, a qual é regulada pelo acúmulo de LHAs no meio. Desta forma, a produção de enzimas degradadoras da parede celular vegetal só ocorre quando a densidade celular está acima de um certo limiar, suficiente para evitar as resposta de defesa da planta (Pirhonen et al., 1993).

Em Xanthomonas spp., a síntese e secreção de proteínas envolvidas na degradação da parede celular e produção de exopolissacarídeos é mediada por um conjunto de genes chamados rpf (regulation of pathogenicity factors). A regulação de genes rpf em Xanthomonas é dependente da densidade celular e da concentração intracelular de ferro (Barber et al., 1997; Wilson et al., 1998). 
X. fastidiosa possui genes com aproximadamente $70 \%$ de identidade de aminoácidos com vários genes rpf de $X$. campestris pv. campestris, inclusive rpfA, sugerindo que essas bactérias possuem mecanismos similares de regulação da síntese de fatores de virulência/patogenicidade.

$\mathrm{Na}$ interação Xylella-citros, devido ao longo tempo entre a infecção pela bactéria e o aparecimento dos sintomas da CVC, é possível que o desenvolvimento da doença seja dependente da densidade celular. Não há evidências da produção de LHAs por $X$. fastidiosa. Genes homólogos a genes da família luxl, responsáveis pela síntese de LHAs, não foram identificados no genoma de $X$. fastidiosa 9a5c. No entanto, genes homólogos a rpfB e rpfF de Xanthomonas campestris pv. campestris, envolvidos na síntese de uma molécula sinal difusível (DSF) e na percepção de quorum, foram identificados. Esses dados sugerem que um mecanismo de percepção de quorum, independente de LHA e similar ao de $X$. campestris pv. campestris, ocorre em $X$. fastidiosa.

As condições ambientais influenciam extremamente as interações planta-microrganismos e podem determinar o grau de predisposição do hospedeiro à infecção e/ou agir direta ou indiretamente sobre o patógeno, favorecendo ou não sua sobrevivência e desenvolvimento (Bedendo, 1995). Tem sido observado que os sintomas de CVC são mais severos em plantas de citros infectadas por $X$. fastidiosa em regiões de temperaturas mais elevadas (Gravena, 1997), sugerindo que o estresse térmico pode induzir a expressão de fatores de patogenicidade/virulência da bactéria. Como vários fatores de patogenicidade/virulência bacterianos são extracelulares e de origem protéica, o conhecimento das proteínas secretadas por $X$. fastidiosa em diferentes condições ambientais é de elevada relevância.

Este trabalho teve como objetivo avaliar a alteração no proteoma extracelular de $X$. fastidiosa $9 \mathrm{a} 5 \mathrm{c}$, durante seu crescimento in vitro à 28 e $32^{\circ} \mathrm{C}$, através de eletroforese bidimensional, e identificar proteínas com acúmulo diferencial. Adicionalmente, bioensaios utilizando sensores bacterianos para 
detecção de lactonas de homoserina aciladas (LHAs) e de moléculas sinais difusíveis, similares ao DSF de $X$. campestris pv. campestris, envolvidas na percepção de quorum, foram realizados para determinar se as mesmas são sintetizadas por $X$. fastidiosa em meio de cultura. 


\section{REVISÃO DE LITERATURA}

\subsection{Clorose variegada dos citros (CVC)}

$\mathrm{Na}$ citricultura brasileira e mundial, a laranja doce [Citros sinensis (L) Osbeck] é a espécie que apresenta maior importância comercial. O Brasil é o maior produtor mundial de laranjas e o Estado de São Paulo é responsável por $80 \%$ desta produção. A citricultura constitui uma atividade econômica essencial para 320 municípios paulistas e 11 do Triângulo Mineiro, empregando cerca de 400 mil pessoas, e utilizando alta tecnologia (Abecitros, 1999).

$\mathrm{Na}$ cultura de citros são descritas várias doenças que causam prejuízos desde a sementeira até a fase adulta da planta. Na década de quarenta, o maior problema fitossanitário na citricultura brasileira foi a tristeza dos citros, destruindo $80 \%$ das árvores cítricas. Na década de sessenta, o cancro cítrico atingiu a região nobre da citricultura paulista, causando grandes prejuízos à economia paulista e brasileira (Hasse, 1987). Atualmente, uma das grandes preocupações é a clorose variegada dos citros (CVC) ou amarelinho, doença identificada oficialmente no Brasil em 1987, em pomares do Triângulo Mineiro e do Norte e Noroeste do Estado de São Paulo. Atualmente, essa ainda é a região mais afetada pela $\mathrm{CVC}$, muito embora a bactéria esteja presente na maioria das áreas citrícolas do país (Donadio \& Moreira, 1997).

A CVC tem como agente causal a $X$. fastidiosa, uma bactéria restrita ao xilema da planta, a qual provoca o bloqueio dos vasos condutores, obstruindo a passagem de nutrientes e água. Em contraste com a maioria das bactérias fitopatogênicas, que têm o vento e água como agentes de disseminação, a $X$. fastidiosa depende exclusivamente das cigarrinhas para infecção da planta 
hospedeira e disseminação nos pomares (Hopkins, 1989). A bactéria também pode ser transmitida através da enxertia de plantas com material contaminado (Purcell \& Hopkins, 1996).

Os sintomas da CVC surgem como uma clorose nas folhas maduras da copa. Posteriormente, na face superior das folhas, verifica-se o aparecimento de pontuações circulares de cor amarela e, na face inferior, lesões de cor palha, às vezes necrosadas. Com o agravamento da doença, os frutos tornam-se queimados pelo sol, com tamanho reduzido, endurecidos, apresentando amarelecimento precoce, o que os desvaloriza comercialmente. Em plantas muito afetadas são observados ramos secos e frutos miúdos (Fundecitrus, 2001).

Todas as variedades de laranjas doce são suscetíveis à CVC, independente do porta-enxerto utilizado. A severidade da doença é maior em plantas mais jovens e diminui gradativamente a partir dos 7 anos de plantio. Tangerinas comerciais não apresentam sintomas da CVC, mesmo quando localizadas em pomares altamente infectados pela bactéria (Carvalho et al., 1995; De Negri \& Garcia Júnior, 1993).

A rápida disseminação da CVC pelos pomares brasileiros e o alto nível de dano causado pela doença têm resultado em grandes perdas econômicas no cultivo de plantas cítricas e para a indústria de suco de laranja (Coletta-Filho \& Machado, 2002).

As cigarrinhas adquirem a bactéria ao alimentarem-se da seiva do xilema de plantas de citros contaminadas e transmitem-as para plantas sadias. Foram descritas onze espécies de cigarrinhas transmissoras da $X$. fastidiosa, as quais pertencem às famílias Cicadellidae (Subfamília Cicadellinae) e Cercopidae. As espécies Agrogonia terminalis, Dilobopterus costalimai e Oncometopia facialis ocorrem mais freqüentemente nas plantas de citros no Estado de São Paulo (Fundecitrus, 2001). 
Basicamente, quatro medidas de controle da CVC têm sido preconizadas: a) uso de mudas livres da CVC para evitar a introdução de inóculo da bactéria em áreas livres da doença; b) poda de ramos com sintomas iniciais da CVC, em plantas com 3 anos ou mais; c) erradicação de plantas infectadas com até 2 anos de idade; e) controle químico dos insetos vetores; além dos cuidados culturais do pomar, normalmente recomendados (Donadio \& Moreira, 1997).

Pesquisas de melhoramento genético para a criação de variedades resistentes à CVC têm sido realizadas. A baixa variabilidade genética observada entre as estirpes de $X$. fastidiosa causadora da CVC, sugere que não existiu uma coevolução entre as variedades de laranja doce e a bactéria, e que a bactéria é pouco especializada. Essas observações favorecem o desenvolvimento de programas de melhoramento visando a resistência à doença (Coletta-Filho \& Machado, 2002).

\subsection{Xylella fastidiosa}

A bactéria Xylella fastidiosa estirpe 9a5c foi o primeiro fitopatógeno a ter seu genoma completamente seqüenciado, revelando um cromossomo circular com 2.679.305 pb e dois plasmídeos de 51.158 e 1.285 pb, os quais são denominados pXF51 e pXF1.3, respectivamente (Simpson et al., 2000).

Comparações de seqüências do RNA ribossômico $16 \mathrm{~S}$ de $X$. fastidiosa

com outras espécies de bactérias, posicionou-a no subgrupo gama de proteobactérias, evolutivamente relacionada com Xanthomonas campestris e $X$. maltophila (Wells et al., 1987).

Xylella fastidiosa é uma bactéria gram-negativa, com formato de bastonete, medindo cerca de 0,25-0,35 x 0,9-3,5 $\mu \mathrm{m}$, não móvel, aflagelada, com parede celular enrugada formada por três camadas. A bactéria é aeróbia estrita e possui crescimento lento, restringindo-se ao xilema das plantas. $O$ crescimento ótimo da bactéria ocorre em pH 6,5-6,9 e temperatura de 26 - 
$28^{\circ} \mathrm{C}$ (Wells et al., 1987). Temperaturas na faixa de 28 à $30^{\circ} \mathrm{C}$ também foram relatadas como ótimas para crescimento da $X$. fastidiosa isolada de videiras (Feil \& Purcel, 2001).

Além de causar a CVC, alguns isolados de $X$. fastidiosa estão associados a outras doenças que causam grandes prejuízos em plantas economicamente importantes, tais como: a doença de Pierce da videira, a escaldadura das folhas do pessegueiro e da ameixeira, a queima das folhas das amendoeira e do carvalho, o nanismo da alfafa, e a queima das folhas do cafeeiro (Hopkins, 1989; Wells et al., 1987; Paradela Filho et al., 1995).

Há confirmação de diversos hospedeiros alternativos da $X$. fastidiosa, como a vinca (Catharanthus roseus), capim carrapicho (Cenchrus echinatus), capim favorito (Rhynchelitrum repens), capim pé-de-galinha (Eleusine indica), grama seda (Cynodon dactylon), guanxuma (Sida sp.), poaia branca (Rhichardia brasiliensis), entre outras (Donadio \& Moreira, 1997).

A bactéria requer meios complexos para crescimento in vitro, e mesmo assim seu crescimento é fastidioso. O tempo de duplicação in vitro de $X$. fastidiosa ocorre entre 10 e 48 horas (Wells et al., 1987).

O meio PW (periwinkle wilt) é o mais amplamente utilizado para o crescimento de estirpes de $X$. fastidiosa (Fry et al., 1990). O meio PW é um meio complexo que contém na sua composição peptona, triptona, hemina clorada, aminoácidos e sais inorgânicos. Esse meio suporta o isolamento e cultivo bacteriano continuado das estirpes mais fastidiosas, como aquelas que causam a doença de Phony do pessegueiro, a escaldadura da folha da ameixeira e a CVC (Campanharo et al., 2003).

Almeida et al. (2001) verificaram que os meios de cultivos PW e PWG favorecem o crescimento de $X$. fastidiosa, encurtando o tempo de incubação da bactéria, aumentando as taxas de recuperação de colônias e resultando no aparecimento de colônias maiores. 
Campanharo et al. (2003), comparando o crescimento de estirpes de $X$. fastidiosa em diferentes meios de cultivo, através de determinações do conteúdo de proteína total e turbidez do meio, demonstraram que o meio PYE, o qual contém extrato de levedura, tampão fosfato e ágar, proporciona os nutrientes necessários para a bactéria. Outros autores já haviam demonstrado que algumas estirpes de $X$. fastidiosa têm alta capacidade de crescimento em meio Nutriente Ágar diluído, contendo extrato de levedura e cloreto de sódio (Kostka et al., 1986; Fry et al., 1990).

O crescimento fastidioso de $X$. fastidiosa em meios de cultivos nutricionalmente ricos demonstra uma falta de capacidade metabólica da bactéria para utilizar os nutrientes do meio, já que ela está adaptada para sobreviver no ambiente do xilema, o qual é nutricionalmente pobre (Van Sluys et al., 2002).

O tamanho relativamente menor do genoma de $X$. fastidiosa 9a5c $(\sim 2,7 \mathrm{Mb})$ em relação ao genoma de $X$. campestris $(\sim 5,5 \mathrm{Mb})$ e a falta do sistema de secreção tipo III em $X$. fastidiosa, sugerem que a bactéria pode representar um patógeno mínimo e que as diferenças podem representar as distintas estratégias de patogenicidade e capacidade de crescimento desses organismos nos seus hospedeiros. A $X$. fastidiosa depende dos insetos vetores para sua transmissão e está confinada aos vasos condutores do xilema onde possui crescimento lento, enquanto $X$. campestris pv. campestris pode infectar plantas diretamente e é capaz de crescer e sobreviver na superfície das folhas de plantas e no solo (Dow \& Daniels, 2000).

\subsection{Regulação das interações $X$. fastidiosa - planta}

A aquisição de $X$. fastidiosa pelos insetos vetores ocorre durante a sucção de seiva do xilema de plantas infectadas. Nos insetos vetores, a $X$. fastidiosa multiplica-se aderida à parede interna da parte anterior do tubo digestivo (estomodeu) e também nas peças bucais e no canal alimentar. Essas 
bactérias são então transmitidas pelo inseto vetor para plantas sadias durante o processo de alimentação. Nas plantas, a bactéria vive confinada aos elementos vasculares do xilema, onde encontra um ambiente físico e nutricional único, com grande diversidade de aminoácidos, íons inorgânicos e ácidos orgânicos e inorgânicos diluídos (Hopkins, 1989).

Hopkins (1989) relata que embora haja um elevado fluxo ascendente de seiva nos vasos, o deslocamento das células de $X$. fastidiosa é refreado, devido a formação de biofilmes, ligando as células umas às outras e aos vasos do xilema e, principalmente, porque o diâmetro dos poros das membranas dos vasos do xilema não são largos o suficiente para permitir que os agregados de $X$. fastidiosa circulem livremente. Observações de cortes longitudinais de pecíolos de folhas de citros com sintomas de CVC, através de microscopia eletrônica de varredura, revelaram nos elementos traqueais do xilema a presença de filamentos semelhantes a fímbrias associados às células de X. fastidiosa, e a presença de agregados bacterianos (Silva \& Rodrigues, 2000).

Algumas hipóteses sobre os mecanismos de patogenicidade de $X$. fastidiosa envolvendo síntese de fitotoxina (Lee et al., 1982), desequilíbrio hormonal (French \& Stassi, 1978) e disfunção do xilema (Hayard \& Mariano, 1997) foram propostas. No entanto, o mecanismo que determina a patogenicidade de $X$. fastidiosa continua desconhecido.

A hipótese mais aceita sugere que o mecanismo primário de patogênese é a diminuição da translocação de água e nutrientes pelo xilema, como resultado da oclusão dos vasos por agregados ou biofilmes bacterianos, gomas e tiloses do hospedeiro (Hopkins, 1989). No entanto, uma simples oclusão dos vasos do xilema não explicaria todos os sintomas da CVC, sugerindo que mecanismos adicionais seriam necessários para a manifestação dos sintomas.

A publicação do genoma da $X$. fastidiosa 9a5c, causadora de CVC, permitiu a formulação de hipóteses mais elaboradas sobre os mecanismos de 
patogenicidade/virulência dessa bactéria, como a produção de toxinas, secreção de enzimas celulolíticas e proteolíticas, seqüestro de íons e formação de biofilmes (Lambais et al., 2000; Simpson et al., 2000; Leite et al., 2001; Meidanis et al., 2002).

Genes codificando toxinas da família RTX foram identificados em $X$. fastidiosa (Simpson et al., 2000). Essas toxinas formam poros que interagem com a membrana plasmática do hospedeiro, causando perda de compostos celulares (Lally et al., 1999). Em animais, essas toxinas estão associadas com a indução de apoptose (Weinrauch \& Zychlinsky, 1999). A produção de toxinas por $X$. fastidiosa pode ser um mecanismo usado para evitar as respostas de defesa da planta hospedeiro (Lambais et al., 2000).

Genes codificando um precursor da poligalacturonase, uma celulase e várias proteases foram identificados em $X$. fastidiosa, bem como toda a maquinaria necessária para secreção de enzimas degradadoras de parede celular de plantas (Simpson et al., 2000). Enzimas secretadas por $X$. fastidiosa que degradam a parede celular da planta podem ter um papel importante na migração vaso-a-vaso, através dos poros das cavidades membranosas do xilema. Alternativamente, a degradação localizada da parede celular da planta pode liberar carboidratos necessários para o crescimento bacteriano no xilema (Lambais et al., 2000).

Alguns íons, especialmente o ferro, magnésio e manganês são essenciais para a sobrevivência de todos os organismos vivo, pois participam como co-fatores de vários complexos enzimáticos importantes. Em $X$. fastidiosa 9a5c foram encontrados genes codificando receptores transmembrânicos envolvidos na absorção de ferro do meio, como também, receptores possivelmente envolvidos na obtenção de manganês. É possível que a redução da disponibilidade desses íons para a planta contribua significativamente para o aparecimento das lesões nas folhas dos hospedeiros (Simpson et al, 2000; Meidanis et al., 2002) 
O bloqueio dos vasos do xilema por biofilmes pode favorecer a sobrevivência bacteriana devido às vantagens nutricionais e de proteção oferecidas pelos biofilmes, permitindo uma cooperação metabólica e facilitando a troca de substratos e a remoção e distribuição de metabólitos entre as células. No genoma de $X$. fastidiosa foram encontrados genes codificando vários genes que podem estar envolvidos no processo de formação de biofilme, como fímbrias e adesinas (Simpson et al., 2000; Leite et al, 2002).

Embora se tenha pouco conhecimento sobre o mecanismo exato da movimentação de $X$. fastidiosa no interior dos vasos, é provável que a degradação das cavidades membranosas do xilema da planta envolva a produção de enzimas extracelulares pela bactéria, como celulases, proteases e pectinases.

Alguns genes estão intimamente envolvidos na especificidade das interações patógeno-hospedeiros, como os genes avr, que são determinantes de avirulência, e os genes hrp, essenciais para o desenvolvimento de respostas de hipersensibilidade e patogenicidade. Os genes avr podem ser essenciais para a multiplicação do patógeno no hospedeiro, como no caso de avrBs2 de $X$. campestris pv. vesicatoria, ou para colonização de citros e a indução de sintomas do cancro, como o pthA de $X$. campestris pv. citri. Na maioria das vezes, as funções dos genes avr são dependentes dos genes hrp (Hayward \& Mariano, 1997).

Os genes hrp são essenciais à patogenicidade e para o desenvolvimento de respostas de hipersensibilidade em plantas hospedeiras resistentes e plantas não-hospedeiras. Proteínas codificadas por genes hrp possuem homologia àquelas requeridas para a transferência de fatores de virulência de muitos patógenos de mamíferos para seus hospedeiros, através do sistema de secreção do tipo III (Grant \& Mansfield, 1999). A expressão dos genes hrp ocorre tanto in planta quanto in vitro. Sua expressão é regulada por 
fontes de carbono e nitrogênio, osmolaridade, $\mathrm{pH}$ e temperatura (Hayward \& Mariano, 1997).

O sistema de secreção do tipo III funciona injetando determinantes de patogenicidade e/ou virulência diretamente no citoplasma das células hospedeiras, os quais podem agir suprimindo respostas de defesa da planta, favorecendo o desenvolvimento da doença, ou promovendo a liberação de nutrientes da célula vegetal. Em alguns casos, esses efetores secretados podem ser reconhecidos pela planta e dispararem o sistema de defesa vegetal, sendo então considerados determinantes de avirulência (Dow \& Daniels, 2000).

No genoma de $X$. fastidiosa 9a5c não foram identificados produtos de genes com seqüência de aminoácidos relacionadas aos produtos dos genes avr conhecidos. Da mesma forma, genes codificando componentes do sistema de secreção tipo III não foram identificados (Simpson et al., 2000). Porém, a $X$. fastidiosa apresenta todas as vias metabólicas conhecidas para a secreção de fatores de virulência extracelulares presentes em bactérias gram-negativas (Keen et al., 2000). Além disso, $X$. fastidiosa possui genes hortólogos aos genes $r p f$ de $X$. campestris pv. campestris, envolvidos em percepção de quorum e regulação da síntese e secreção de fatores de patogenicidade (Dow \& Daniels, 2000).

\subsection{Mecanismos de patogenicidade elou virulência}

Patogenicidade e virulência são termos que definem a capacidade de um micorganismo em causar doença em um hospedeiro suscetível, através de um conjunto de recursos que possibilitam sua sobrevivência e multiplicação no hospedeiro.

A patogenicidade é definida como a habilidade de um organismo em causar doença e a virulência é a capacidade relativa desse organismo de infectar o hospedeiro. Os fatores de patogenicidade são atributos essenciais de 
um patógeno, enquanto os fatores de virulência aumentam a severidade da doença (Hayard \& Mariano, 1997).

A patogenicidade refere-se, então, aos mecanismos de infecção e desenvolvimento da doença e a virulência mede a intensidade da patogenicidade. O grau de virulência está diretamente relacionado a capacidade de um microrganismo em causar a doença a despeito dos mecanismo de defesa do hospedeiro. Desta forma, pode-se classificar os fatores de virulência em duas categorias: fatores que promovem a colonização ou a invasão dos tecidos do hospedeiro e os fatores que causam danos ao hospedeiro pela produção de enzimas e toxinas.

\subsubsection{Secreção de fatores de patogenicidade/virulência em bactérias}

Se por uma lado as plantas lançam mão de seus mecanismos de defesa para impedir a entrada de patógenos ou para restringir sua atividade, os fitopatógenos, por sua vez, possuem mecanismos que favorecem sua penetração e crescimento nas plantas hospedeiras. Desta forma, para o entendimento das interações patógeno-hospedeiro é necessário um melhor entendimento dos sistemas de secreção bacterianos, os quais são fundamentais para a secreção de proteínas e outras moléculas associadas à patogenicidade.

A secreção de proteínas é considerado um dos principais mecanismos de virulência bacteriano. As proteínas destinadas ao ambiente extracelular das bactérias gram-negativas precisam atravessar a membrana citoplasmática e a membrana externa, as quais estão separadas pelo compartimento periplasmático e pela camada de peptidioglicana, a fim de translocarem-se através do envelope celular bacteriano (Sandkvist, 2001).

Até hoje, os sistemas para secreção de proteínas em bactérias que foram identificados, incluem os sistemas de secreção do tipo I, II, III, IV, V, sistema de secreção de hemaglutininas ou TPS e os autotransportadores 
(Sandkvist, 2001). Lory (1998) propôs que o sistema de secreção pelo qual proteínas individuais são secretadas é determinado, em parte, pela função que elas desempenham no sítio extracelular onde são liberadas. Dentre esses sistemas de secreção, o do tipo II é de grande relevância para a secreção de fatores de patogenicidade/virulência extracelulares em patógenos vegetais.

O sistema de secreção tipo II foi descrito inicialmente em Klebsiella oxytoca, um patógeno oportunista causador de infecções em humanos, e é requerido para a secreção da pululanase (D’Enfert et al., 1987). Desde então, este sistema de secreção tem sido identificado em inúmeras espécies bacterianas, incluindo muitos patógenos humanos, como Vibrio cholerae e Pseudomonas aeruginosa; patógenos de peixes, como Aeromonas hydrophila e patógenos de plantas, como Erwinia chrysanthemi, Erwinia carotovora e Xanthomonas campestris (Salmond, 1994). O seqüenciamento do genoma de $X$. fastidiosa 9a5c revelou a presença de um agrupamento de genes codificando proteínas associadas ao sistema de secreção do tipo II, homólogos àqueles relatados em $X$. campestris (Simpson et al., 2000).

Tem-se conhecimento que as bactérias fitopatogênicas podem produzir vários fatores de virulência extracelulares, como as enzimas degradadoras da parede celular, entre elas as celulases, pectinase, proteases e xilanases secretados por E. carotovora e E. chrysanthemi; as poligalacturonases, amilases, proteases e endoglucanases secretados por X.campestris; as lipases, fosfolipases, elastases e fosfatases secretados por $P$. aeruginosa (Whitehead et al, 2001).

Em $X$. campestris pv. campestris a secreção de enzimas extracelulares é feita através do sistema de secreção tipo II, o qual é codificado por um agrupamento contendo 11 genes, xpsEFGHIJKLMND (Dums et al., 1991; Lee et al., 2000). O sistema de secreção do tipo II é requerido para a virulência de $X$. campestris pv. campestris e X. oryzae pv. oryzae (Dow et al., 1987; Ray et al, 2000). 
A mesma organização do agrupamento xps encontrado em $X$. campestris pv. campestris ocorre em $X$. fastidiosa ( $g s p)$, onde o sistema de secreção tipo II provavelmente está envolvido na exportação de enzimas degradadoras de parede celular, incluindo endoglucanases (XF0810, XF0818, $X F 2708)$, poligalacturonase (XF2466) e talvez muitas proteases (XF2330, XF0267, XF1851, XF0816) (Dow \& Daniels, 2000)

A degradação da parede celular vegetal através de enzimas secretadas por $X$. fastidiosa poderia favorecer a migração da bactéria entre os vasos do xilema, bem como liberar carboidratos necessários para o crescimento bacteriano no xilema, devido a degradação localizada da parede celular vegetal (Lambais et al., 2000).

A expressão dos genes envolvidos no sistema de secreção do tipo II, em alguns casos, estão sob o controle de mecanismos de percepção de quorum ou são estritamente regulados pelas condições do ambiente no sítio de colonização do patógeno (Sandkvist, 2001). Desta foram, a secreção de fatores de patogenicidade/virulência protéicos pode ser dependente da fase de crescimento bacteriano ou estritamente regulada por sinais ambientais .

Em E. carotovora, uma bactéria causadora de podridão em várias espécies de plantas, a síntese e secreção de enzimas degradadoras da parede celular é induzida em condições de alta densidade celular (Pirhornem et al., 1993).

A secreção de fatores de patogenicidade/virulência em muitas bactérias é um fenômeno afetado por uma variedade de parâmetros, incluindo a temperatura.

Em P. syringae pv. glycinea a secreção de alguns fatores de avirulência, através do sistema de secreção dependente de Hrp (tipo III), pode ser afetada pela temperatura. A concentração de HrpA no sobrenadante de culturas é mais elevada à $18-22^{\circ} \mathrm{C}$ do que à $25-30^{\circ} \mathrm{C}$. Da mesma forma, a secreção de AvrPto é mais elevada à $20^{\circ} \mathrm{C}$ do que à $30^{\circ} \mathrm{C}$. Já a secreção de 
HrpZ não é afetada pela temperatura (Van Dijk et al., 1999). Da mesma forma, a temperatura pode ter efeito direto na atividade do fator de patogenicidade/virulência. Tardy et al. (1997) analisaram a atividade de pectinases em E. chrysanthemi sob condições de estresse térmico e verificaram que cada isoenzima possui um ótimo de temperatura para sua atuação.

A maior severidade da CVC no Estado de São Paulo tem sido associada ao aumento da temperatura ambiente e à deficiência hídrica (Gravena, 1997). Foi observado que o clima mais quente e a falta de chuvas favorece o desenvolvimento da doença nas regiões norte e noroeste do Estado de São Paulo, as quais apresentam uma incidência da CVC cerca de 17\% superior às outras regiões (Fundecitrus, 2001).

Adicionalmente, foi observado que os sintomas do mal de Pierce em videiras, causada por $X$. fastidiosa, também aparecem mais precocemente em regiões de clima quente. Feil \& Purcell (2001), através de inoculações de $X$. fastidiosa em videiras localizadas em regiões mais frias e mais quentes da Califórnia, demonstraram diferenças não somente no tempo de aparecimento dos sintomas, mas também na extensão dos sintomas do mal de Pierce, confirmando a influência da temperatura na epidemiologia da doença.

Entretanto, quando esses pesquisadores avaliaram a influência da temperatura no crescimento in vitro de $X$. fastidiosa causadora do mal de Pierce, obtiveram resultados contraditórios. Feil e Purcell (2001) verificaram que o pico da população bacteriana ocorreu após 6 dias de incubação em meio PW à $28^{\circ} \mathrm{C}$. Após 3 dias de incubação neste meio, a população de células foi cerca de 20 vezes menor à $32^{\circ} \mathrm{C}$ do que à $28^{\circ} \mathrm{C}$.

Os fatores de patogenicidade/virulência de $X$. fastidiosa não foram identificados, mas por analogia de funções, há vários candidatos. Pelas características do desenvolvimento dos sintomas da CVC em citros, é possível especular que esses fatores de patogenicidade/virulência poderiam ser regulados por estresses térmicos. Muito embora o crescimento de $X$. fastidiosa 
no sistema vascular das plantas cítricas seja afetado não somente pela temperatura, o conhecimento sobre os efeitos de estresses térmicos no crescimento e secreção de proteínas podem ser úteis para o entendimento de como a temperatura pode afetar o crescimento da bactéria in planta.

\subsubsection{Percepção de quorum em bactérias fitopatogênicas}

Percepção de quorum é o mecanismo pelo qual as bactérias regulam um processo fisiológico em resposta à sua densidade populacional (Fuqua et al, 1994; 1996).

A densidade populacional em várias bactérias gram-negativas é monitorada através de moléculas sinais difusíveis e revela um comportamento multicelular em organismos procariotos. Tem sido demonstrado que a percepção de quorum é importante para o controle da produção de metabólitos secundários, desenvolvimento de simbiose, formação de biofilmes e virulência. Em P. aeruginosa, um dos sistemas de percepção de quorum melhor estudados, a percepção de moléculas de sinalização afeta direta e/ou indiretamente a expressão de cerca de 200 genes (Whiteley et al., 1999).

O mecanismo de percepção de quorum foi relatado pela primeira vez em Vibrio fischeri, uma bactéria que vive livremente na água do mar ou em simbiose com lulas e peixes. O exemplo mais estudado envolve a simbiose entre $V$. fischeri e Euprymna scolopes, uma pequena lula que possui órgãos luminescentes, devido a presença da bactéria em alta densidade (Ruby, 1999; Yisick \& McFall-Ngai, 2000). A luminescência produzidas por estes víbrios marinhos é resultado de um processo de autoindução mediado por lactonas de homoserina aciladas (LHAs), chamadas de autoindutores (Als). Essas moléculas sinais são sintetizadas pelas células, difundem-se através da membrana plasmática e acumulam-se no ambiente de maneira dependente da população bacteriana. Uma vez atingido um certo limiar de concentração, os 
Als interagem com proteínas regulatórias para ativar ou reprimir a transcrição do operon lux (luxICDABEG) (Fuqua et al., 1994; Fuqua et al., 1996).

A regulação da expressão dos genes lux é mediada por duas proteínas, Luxl e LuxR. O Al é sintetizado pelo produto do gene luxl, e é um co-fator de transcrição. Autoindutores ligam-se ao produto do gene luxR, um fator de transcrição dependente de Als, o qual no estado ativo ligar-se-á a seqüências regulatórias do promotor lux (lux boxes), ativando a transcrição dos operons lux (Fuqua et al., 1996).

Várias moléculas sinalizadoras de quorum têm sido identificadas e pertencem a famílias quimicamente distintas (Whitehead et al., 2001). Embora o mecanismo de percepção de quorum mediado por LHAs seja o mais intensamente investigado, nem todas as bactérias comunicam-se usando este tipo de sinalização. Outras moléculas produzidas por diferentes bactérias estão associadas com sinalização de quorum, dentre elas, o Al-2 (furanosil borato diéster), produzido por $V$. harveyi (Chen et al., 2002); butirolactona produzida por Streptomyces (Yamada \& Nihira, 1998); oligopeptídeos produzidos por espécies gram-negativas (Noviek \& Muir, 1999, Kleerebezem \& Quadri, 2001); dipeptídeos cíclicos produzidos por várias bactérias gram-negativas (Holden et al. 1999) e bradyoxetina sintetizada por Bradyrhizobium japonicum (Loh et al., 2002). As bactérias Ralstonia solanacearum e X.campestris utilizam sistemas únicos para sinalização de quorum e para regulação de fatores de patogenicidade, baseados em butirolactonas e derivativos de ácidos graxos, respectivamente (Barber et al., 1997; Chun \& Cui, 1997; Flavier et al., 1997).

A detecção de moléculas sinalizadoras envolvidas na percepção de quorum tem sido bastante facilitada devido ao desenvolvimento de sistemas repórteres, já que elas são produzidas em concentrações extremamente baixas pelas células bacterianas. Ainda assim, existe a necessidade de extração com solventes orgânicos e concentração por cromatografia.

A produção de moléculas sinalizadoras é um processo estritamente dependente dos parâmetros de crescimento, como fontes de carbono e temperatura. 
Assim, o estágio de crescimento bacteriano e a composição do meio de cultivo exercem grande influência no nível de moléculas sinalizadoras de quorum produzidas (BrellesMariño \& Bedmar , 2001).

Muitos autores têm utilizado meio mínimo para a produção de moléculas sinalizadoras de percepção de quorum em bactérias, com a extração dessas moléculas no final da fase exponencial de crescimento ou no início da fase estacionária (Cha et al., 1998; Shaw et al., 1997, Pearson et al., 1994).

Eberhard (1972) detectou a presença de um inibidor da sinalização celular quando do crescimento de $V$. fischeri em meio complexo, e a ausência desse inibidor quando em meio mínimo, sugerindo que o fenômeno da autoindução ocorre somente em meio mínimo.

Pearson et al. (1994) observaram que a concentração de moléculas sinalizadoras foi muito maior na metade da fase logarítmica de crescimento de $P$. aeruginosa quando comparada à fase estacionária. Contrariamente, Lithgow et al. (2000) detectaram concentrações maiores de moléculas sinalizadoras produzidas por $R$. leguminosarum em meio complexo, durante a fase estacionária. As razões para estas diferenças nos estágios de crescimento são desconhecidas.

Para a detecção das LHAs têm sido utilizados vários sistemas repórteres (Swift et al., 1993, Cha et al., 1998, Gram et al., 1999), baseados em uma resposta fenotípica (bioluminescência, produção de violaceína ou atividade da $\beta$-galactosidase) ativada através de uma proteína receptora de LHAs (McClean et al., 1997).

Agrobacterium tumefaciens, E. carotovora, P. aeruginosa, $P$. aureofaciens, Escherichia coli e R. leguminosarum possuem mecanismos de percepção de quorum homólogos ao sistema LuxR/LuxI de V. fischeri (Cubo et al, 1992; Fuqua et al., 1994, 1996).

As moléculas sinalizadoras desempenham papéis importantes na regulação de diferentes funções em diferentes espécies bacterianas, como a transferência conjugativa do plasmídeo indutor de tumor (Ti) em Agrobacterium tumefaciens; inibição do crescimento em B. japonicum USDA110; biossíntese 
do antibiótico carbapen e a síntese da enzima pectato-liase em E. carotovora; síntese de exopolissacarídeos em Erwinia stewarti; produção do antibiótico fenazina em $P$. aureofaciens e $P$. fluorescens; nodulação em $R$. etli; inibição do crescimento, transferência de plasmídeo e indução de genes para a sobrevivência na rizosfera em $R$. leguminosarum bv. viciae; produção de determinantes de virulência (enzimas extracelulares e exopolissacarídeos) em X. campestris (Brelles-Mariño \& Bedmar, 2000).

Está claro que uma variedade de espécies bacterianas fitopatogênicas possuem mecanismos de sinalização de quorum e que estes mecanismos influenciam a expressão de fatores de patogenicidade.

A virulência em $E$. carotovora depende da produção e secreção de enzimas degradadoras da parede celular vegetal (celulases, pectato-liases, pectinases e poligalacturonases), via sistema de secreção tipo II, a qual é regulada pela densidade celular no meio. Mutação no gene epxl de $E$. carotovora, homólogo ao gene luxl de $V$. fischeri, reduz a capacidade para a produção das enzimas degradadoras da parede celular e a habilidade de causar podridão nas plantas hospedeiras (Jones et al., 1993; Pirhonem et al., 1993).

A expressão do agrupamento de genes out de $E$. carotovora e a secreção das proteínas correspondentes, são altamente induzidas no início da fase estacionária de crescimento, sugerindo que estes genes também estão sob o controle de um sistema de percepção de quorum (Lindeberg \& Collmer, 1992).

Em $X$. fastidiosa genes homólogos aos genes da família lux। não foram identificados (Simpson et al., 2000). No entanto, dois genes codificando proteínas homólogas à proteínas da família LuxR de ativadores transcricionais foram encontrados (Lambais et al., 2000). Não há evidências da produção de LHA por $X$. fastidiosa mas, devido ao longo tempo entre a infecção e o 
aparecimento de sintomas da CVC, o desenvolvimento dos sintomas pode depender da densidade de células da $X$. fastidiosa no xilema.

A análise do genoma de $X$. fastidiosa sugere a existência de mecanismos de sinalização de quorum independentes de LHAs e similares aos que ocorrem em $X$. campestris (Lambais et al., 2000).

Em $X$. campestris pv. campestris, a regulação da síntese de enzimas envolvidas na degradação da parede celular e de polissacarídeos extracelulares é mediada por um conjunto de nove genes denominados rpf (regulation of pathogenicity factors): rpfABFCHGDIE (Tang et al., 1991; Barber et al., 1997; Wilson et al., 1998; Dow \& Daniels, 2000). No genoma da $X$. fastidiosa existe uma região com alta homologia à região cromossômica de $\mathrm{X}$. campestris $\mathrm{pv}$. campestris que contém o agrupamento de genes rpf (Dow \& Daniels, 2000). No entanto, no genoma de $X$. fastidiosa não foi encontrado o gene rpfl, o qual também não está presente em $X$. axonopodis pv. citri. Em $X$. campestris pv. campestris, os níveis de expressão de protease e celulase são reduzidos quando o gene rpfl é inativado, sugerindo que esse gene pode agir na degeneração massiva do tecido que é observada em podridões moles causadas por essa bactéria, o que não é observado em plantas infectadas com $X$. fastidiosa ou $X$. axonopodis pv. citri (Dow \& Daniels, 2000).

Os genes rpfB e rpfF estão envolvidos na síntese de DSF, a qual pode ser importante para a percepção de quorum de $X$. campestris pv. campestris. $O$ gene rpfF é essencial para a síntese de DSF, já que mutantes rpfF- não sintetizam DSF, muito embora respondam à adição de DSF ao meio (Barber et al., 1997).

Produtos dos genes rpfF e rpfB não possuem relação com as proteínas das famílias LuxR/Luxl ou outras proteínas envolvidas nesse sistema de percepção de quorum. O DSF sintetizado por $X$. campestris pv. campestris não é um autoindutor como as LHAs sintetizadas por várias bactérias gramnegativas (Barber et al., 1997). 
Normalmente, concentrações mais elevadas de DSF de $X$. campestris pv. campestris em meio de cultura, são observadas no início da fase estacionária, diminuindo posteriormente (Barber et al., 1997).

Em X. campestris pv. campestris, rpfA codifica a isoforma mais abundante de aconitase, atuando na homeostase de ferro como reguladora da expressão de genes envolvidos na síntese de exopolissacarídeos e de genes codificando enzimas extracelulares (protease-serina e endoglucanase) (Wilson et al., 1998). O rpfC codifica uma proteína regulatória de um sistema de dois componentes, provavelmente envolvida na percepção de DSF, ativação de genes de patogenicidade e regulação negativa de DSF (Tang et al., 1991; 1996). Tem sido proposto que os produtos dos genes rpfG, rpfH e rpfC participam de um sistema de transdução de sinais ligado à percepção de sinais ambientais, incluindo, talvez, o próprio DSF (Slater et al., 2000). Em X. oryzae pv. oryzae, o gene rpfC está envolvido na patogenicidade, contribuindo mais para a manifestação dos sintomas da doença do que para o crescimento e sobrevivência da bactéria dentro da planta (Tang et al., 1991).

Em $X$. fastidiosa os genes rpfA, rpfB e rpfF são funcionais. A expressão de rpfA foi detectada apenas em condições de alta densidade celular, enquanto a expressão de rpfB só foi detectada sob condições de baixa densidade celular, já o rpfF teve sua expressão induzida sob condições de alta densidade celular (Scarpari, 2001).

A indução do rpfa de $X$. fastidiosa em condições de alta densidade celular, sugere que esse gene codifica a aconitase que participa do ciclo do ácido cítrico. Alternativamente, o produto de rpfA poderia contribuir para o aumento da disponibilidade de ferro intracelular sob condições de alta densidade celular, já que o produto do rpfA de $X$. campestris pv. campestris tem a capacidade de ligar-se ao ferro e pode estar envolvido na homeostase do mesmo. 
Diferentemente do que foi observado em $X$. campestris pv. campestris, os genes rpfF e rpfB da $X$. fastidiosa estão em operons diferentes, podendo não apresentar co-regulação (Silva et al., 2001). Desta forma, Scarpari (2001) sugere que esta diferença pode explicar porque somente houve a indução do gene rpfF de $X$. fastidiosa sob condições de alta densidade celular.

Não está provada a ação do DSF na percepção da densidade celular durante o crescimento de $X$. campestris pv. campestris, mas especula-se que os nutrientes solúveis na seiva do xilema podem suportar o crescimento bacteriano até um certo nível, a partir do qual a bactéria sofrerá privação de nutrientes. A produção de enzimas extracelulares para degradação de macromoléculas do xilema da planta e sua utilização como substrato, poderia aliviar a privação de nutrientes e permitir o crescimento bacteriano (Barber et al., 1997).

Uma molécula sinalizadora difusível e de baixa massa molecular, produzida por diferentes estirpes de $X$. campestris pv. campestris, parece estar envolvida na regulação da síntese do pigmento xantomonadina e também na produção de exopolissacarídeos. Este fator é chamado de DF e foi caracterizado como uma butirolactona. Tem sido demonstrado que DF contribui para a sobrevivência epifítica de $X$. campestris pv. campestris (Whitehead et al., 2001).

Se os genes rpfB e rpfF estão envolvidos na síntese de um DSF em $X$. fastidiosa não é conhecido e merece uma investigação mais detalhada. 


\section{METODOLOGIA}

\subsection{Crescimento da $X$. fastidiosa em meio PW modificado}

A bactéria Xylella fastidiosa 9a5c foi cultivada em meio de cultura PW (Davies et al., 1981) modificado líquido (ANEXO A). Essa modificação foi feita retirando-se dois componentes do meio original, a fração $V$ da albumina de soro bovino (ASB) e o vermelho de fenol.

O inóculo da bactéria foi obtido de culturas estoques em glicerol armazenadas à $-80^{\circ} \mathrm{C}$, as quais foram primeiramente plaqueadas em meio PW modificado agarizado, com incubação à $28^{\circ} \mathrm{C}$ durante 10 dias. Logo após, as células foram removidas da superfície do meio e transferidas para tubos contendo $1 \mathrm{~mL}$ de meio PW modificado líquido. Após 10 dias de incubação, adicionou-se um volume de $1 \mathrm{~mL}$ de meio $\mathrm{PW}$ modificado líquido, permanecendo as células incubadas por mais 10 dias à $28^{\circ} \mathrm{C}$. Esse processo foi repetido mais uma vez. Passado esse período, as células de $X$. fastidiosa cultivadas em vários tubos foram transferidas para frascos contendo $30 \mathrm{~mL}$ de meio PW modificado líquido, e incubadas durante 7 dias à $28^{\circ} \mathrm{C}$ e agitação orbital de $150 \mathrm{rpm}$. Essa cultura foi utilizada como inóculo inicial para determinação das curvas de crescimento.

Para a determinação das curvas de crescimento de $X$. fastidiosa à 28 ou $32^{\circ} \mathrm{C}$, utilizou-se erlenmeyers com capacidade de $50 \mathrm{~mL}$, contendo $20 \mathrm{~mL}$ do meio PW modificado líquido, ao qual adicionou-se $1 \mathrm{~mL}$ de inóculo da bactéria. Durante o período de avaliação do crescimento, as células bacterianas foram incubadas em agitador orbital à 150 rpm, durante 16 dias. 
O crescimento de $X$. fastidiosa foi monitorado através da determinação da absorbância de uma suspensão de células em solução salina à $600 \mathrm{~nm}$ $\left(A_{600}\right)$. As determinações foram feitas imediatamente após a adição do inóculo (tempo 0) e 4, 7, 10, 13 e 16 dias após a inoculação. A absorbância do inóculo inicial também foi determinada. Para as determinações de $A_{600}$, foram escolhidos aleatoriamente 3 erlenmeyers, dos quais se retirou alíquotas de 1 $\mathrm{mL}$ da suspensão celular. Essa suspensão foi transferida para microtubos e centrifugada por 10 minutos à $10.000 \mathrm{~g}$. O pélete resultante foi ressuspendido em $1 \mathrm{~mL}$ de solução salina 0,8\%, e a absorbância determinada. Como prova em branco utilizou-se a solução salina $0,8 \%$.

A porcentagem de células viáveis na cultura, em relação ao total de células, foi determinada utilizando-se o Kit "Live/Dead ${ }^{\circledR}$ Baclight BacterialTM Viability" (Molecular Probes). Essa determinação foi realizada pois células de $X$. fastidiosa anteriormente avaliadas em curvas de crescimento, tornavam-se escuras e não se multiplicavam satisfatoriamente, após 10 dias de incubação, sugerindo que elas poderiam estar morrendo rapidamente sob as condições de nossos experimentos. O ensaio foi realizado em microplacas. Uma alíquota da suspensão bacteriana, após os diferentes tempos de incubação, foi misturada com o mesmo volume dos corantes SYTO 9 e Propidium iodine $50 \%$ em água destilada e desionizada. As amostras foram incubadas por 15 minutos no escuro. As intensidades de fluorescências à 530nm (verde) e 610nm (vermelho) foram determinadas utilizando-se um densitômetro a laser "Fluorlmager" (Amersham Bioscience). As análises foram feitas utilizando-se o programa "Image Quant" (Amersham Bioscience).

Adicionalmente, utilizou-se a técnica de diluição e plaqueamento para a contagem do número de unidades formadoras de colônias (UFC) da bactéria. Imediatamente após a adição do inóculo e após 4, 7, 10, 13 e 16 dias de incubação, retirou-se uma alíquota de $100 \mu \mathrm{L}$ do meio contendo as células de $X$. fastidiosa de um dos frascos utilizados para a determinação da absorbância. 
Esse volume foi transferido para um microtubo contendo $900 \mu \mathrm{L}$ de solução salina $0,8 \%$, obtendo-se uma suspensão $10^{-1}$. Esse processo foi repetido sucessivamente para a obtenção de uma suspensão $10^{-6}$. Um volume de $100 \mu \mathrm{L}$ de cada uma das diluições foi plaqueado em meio PW modificado agarizado e incubado à 28 ou $32^{\circ} \mathrm{C}$, durante cerca de 10 dias. Foram feitas 3 repetições de cada diluição. Após esse período foi feito a contagem das colônias bacterianas utilizando um microscópio estereoscópico.

O experimento para a determinação da curva de crescimento da $X$. fastidiosa seguiu um delineamento inteiramente casualizado e foi analisado em um esquema fatorial $2 \times 5$ (temperatura $\times$ tempo). Para análise dos resultados, foi adotado o software "R: A Programming Environment for Data Analysis and Graphics", versão 1.7.1, 2003 (Ihaka \& Gentleman, 1996). Os resultados foram previamente avaliados quanto a homogeneidade de variância pelo teste de Bartlett. Procedeu-se análise de variância (ANOVA) e avaliação de normalidade dos resíduos pelo teste de Shapiro-Wilk. Para comparação múltipla de médias adotou-se o teste de Tukey ao nível de 5\% de probabilidade.

\subsection{Extração de proteínas extracelulares produzidas por $X$. fastidiosa}

Proteínas extracelulares foram extraídas do meio de cultura dos mesmos frascos utilizados para a determinação das curvas de crescimento no item 3.1. O meio PW modificado líquido contendo células de $X$. fastidiosa foi transferido para tubos cônicos de $40 \mathrm{~mL}$ e centrifugado à $10.000 \mathrm{~g}$ por 8 minutos, à $4^{\circ} \mathrm{C}$. O sobrenadante acelular foi utilizado para a extração de proteínas.

Alíquotas de $10 \mathrm{~mL}$ do sobrenadante acelular contendo as proteínas extracelulares foram precipitadas com $20 \mathrm{~mL}$ de uma solução de acetona:etanol $(1: 1 ; \mathrm{v}: \mathrm{v})$ durante 12 horas à $-20^{\circ} \mathrm{C}$. Posteriormente, as proteínas foram recuperadas através de centrifugação à $10.000 \mathrm{~g}$ por 25 minutos à $4^{\circ} \mathrm{C}$ e secas à vácuo. $\mathrm{O}$ pélete foi solubilizado em $1 \mathrm{~mL}$ de uma solução contendo $10 \mathrm{mM}$ 
Tris- $\mathrm{HCl}(\mathrm{pH}$ 8,8), $3 \mathrm{mM}$ de $\mathrm{KCl}$ e $50 \mathrm{mM}$ de $\mathrm{NaCl}$, seguido de centrifugação à $11.000 \mathrm{~g} \mathrm{e} 4^{\circ} \mathrm{C}$. Esse processo foi repetido três vezes para clarificação do extrato protéico. As proteínas foram quantificadas e armazenas à $-80^{\circ} \mathrm{C}$ para posterior análises através de 2D-PAGE.

\subsection{Análises moleculares da $X$. fastidiosa utilizada nos experimentos}

\subsubsection{Extração do DNA}

A extração do DNA foi realizada conforme Ausubel (1989). Uma alíquota de $50 \mathrm{~mL}$ da suspensão bacteriana em meio PW modificado líquido foi centrifugada por 5 minutos à $15000 \mathrm{~g}$. O pélete foi ressuspendido em $567 \mu \mathrm{L}$ de TE, logo após foi adicionado SDS $(0,5 \%)$ e proteinase $K(100 \mu \mathrm{g} / \mathrm{mL})$, incubando-se por 1 hora à $37^{\circ} \mathrm{C}$. Então, foram adicionados $100 \mu \mathrm{L}$ de $\mathrm{NaCl} 5 \mathrm{M}$ e $80 \mu \mathrm{L}$ de $\mathrm{CTAB} 10 \%$, incubando-se novamente por 10 minutos à $65^{\circ} \mathrm{C}$. Em seguida foi feita uma extração com um volume de fenol:clorofórmio:álcool isoamílico (25:4:1; v:v), e outra extração com $700 \mu \mathrm{L}$ de clorofórmio:álcool isoamílico (2:4:1; v:v). O DNA foi precipitado com 0,6 volumes de isopropanol à $-20^{\circ} \mathrm{C}$ por 2 horas. O pélete foi lavado primeiramente com etanol $70 \%$ gelado e depois com etanol absoluto gelado, sendo seco e ressuspendido em $50 \mu \mathrm{L}$ de TE. Adicionou-se $15 \mu \mathrm{g}$ de RNase e a solução foi incubada por 1 hora à $37^{\circ} \mathrm{C}$.

A concentração do DNA foi determinada através de espectrofotometria à $260 \mathrm{~nm}\left(\mathrm{OD}_{260}=50 \mu \mathrm{g}\right.$ de $\left.\mathrm{DNA} \mathrm{mL} \mathrm{L}^{-1}\right)$, e sua integridade por eletroforese em gel de agarose $1,2 \%$ - TBE.

\subsubsection{Amplificação de fragmento diagnóstico da $X$. fastidiosa}

Utilizou-se uma alíquota de 30 ng do DNA obtido, para amplificação por PCR de regiões específicas do genoma da $X$. fastidiosa, utilizando-se os iniciadores CVC1 e CVC272-2int (Pooler \& Hartung, 1995). As amplificações por PCR foram realizadas nas seguintes condições: solução tampão PCR 1X 
(Amersham Bioscience), dNTPs (Gibco-BRL) $200 \mu \mathrm{M}$, iniciadores CVC1 e CVC272-2int. (0,4 $\mu \mathrm{M})$ e 1,0 U de DNA polimerase Taq (Amersham Bioscience), em volume final de $25 \mu \mathrm{L}$. A amplificação foi realizada em um ciclo à $94^{\circ} \mathrm{C}$ por 3 minutos, e 35 ciclos de 1 minuto à $94^{\circ} \mathrm{C}, 1$ minuto à $50^{\circ} \mathrm{C}$ e 1 minuto à $72^{\circ} \mathrm{C}$, e uma extensão final por 4 minutos à $72^{\circ} \mathrm{C}$. O produto da PCR (amplicon de 500 $\mathrm{pb}$ ) foi detectado por eletroforese em gel de agarose 0,6\%-TBE.

\subsection{Eletroforese bidimensional (2D-PAGE) de proteínas extracelulares de $X$. fastidiosa}

\subsubsection{Focalização isoelétrica}

Um volume contendo $100 \mu \mathrm{g}$ proteínas extracelulares secretadas em meio PW modificado líquido foram precipitadas com 2 volumes de solução de acetona:etanol (1:1; v:v), recuperadas por centrifugação à $10.000 \mathrm{~g}$ por 25 minutos, e secas à temperatura ambiente. $O$ pélete foi ressolubilizado em solução contendo $50 \mathrm{mM}$ de Tris- $\mathrm{HCl}(\mathrm{pH}$ 8,8), $100 \mathrm{mM}$ de DTT e 0,5\% de SDS, à $95^{\circ} \mathrm{C}$ por 5 minutos. Em seguida, as proteínas foram tratadas com $8 \mathrm{M}$ uréia, 4\% CHAPS, 70 mM DTT, 0,8\% de tampão IPG pH 3-10 não-linear (Amersham Bioscience), 0,005\% de azul de bromofenol. A solução foi agitada por 1 minuto, seguido de descanso por 1 hora e novamente agitação por 1 minuto. A focalização isoelétrica foi feita utilizando-se fitas de IPG (gradiente de poliacrilamida imobilizado) de $18 \mathrm{~cm}$ de comprimento e gradiente de $\mathrm{pH}$ 3-10 não-linear em um aparato de focalização isoelétrica IPGphor (Amersham Bioscience). No primeiro estágio da focalização isoelétrica, utilizou-se $150 \mathrm{~V}$ durante 1 hora; no segundo estágio utilizou-se $350 \mathrm{~V}$ durante 1 hora; no terceiro estágio $500 \vee$ por 1 hora; no quarto estágio $1000 \mathrm{~V}$ por 1 hora; no quinto estágio $5000 \mathrm{~V}$ por 1 hora; no sexto estágio $8000 \mathrm{~V}$ até atingir $60 \mathrm{kVh}$.

Após a focalização isoelétrica, as fitas de IPG foram lavadas com água destilada e desionizada e equilibradas em duas soluções redutoras de pontes 
de dissulsulfetos. Na primeira solução de equilíbrio, em $50 \mathrm{mM}$ de Tris- $\mathrm{HCl}(\mathrm{pH}$ 6,8), $6 \mathrm{M}$ de Uréia, 30\% (v/v) de glicerol, $2 \%$ de SDS e 2\% de DTT, as fitas de IPG permaneceram por 12 minutos. Na segunda solução de equilíbrio, contendo $50 \mathrm{mM}$ de Tris- $\mathrm{HCl}(\mathrm{pH}$ 6,8), $6 \mathrm{M}$ de Uréia, 30\% (v/v) de glicerol, 2\% de SDS , 2,\% de iodoacetamida e 0,05\% de azul de bromofenol, as fitas permaneceram durante 5 minutos.

\subsubsection{SDS-PAGE}

A segunda dimensão da eletroforese foi feita em um gel vertical homogêneo contendo $12,5 \%$ de acrilamida/bis-acrilamida (37,5:1, m:m), 1,5 M de Tris- $\mathrm{HCl}(\mathrm{pH} 8,8), 0,1 \%$ de persulfato de amônia e 0,05\% de TEMED. Após as fitas IPG terem sido equilibradas, elas foram colocadas sobre o gel da segunda dimensão e cobertas com uma solução de 0,5\% de agarose em tampão de corrida Tris-Glicina (25 mM Tris-HCl, 192 mM glicina e 0,1\% SDS). A separação eletroforética das proteínas foi feita no sistema SE 600 (Amersham Bioscience) onde foi conectado um sistema refrigerador Multitemp II (Amersham Bioscience), para manutenção da temperatura na cuba à $8^{\circ} \mathrm{C}$. Na primeira etapa utilizou-se $90 \vee$ fixos durante 1 hora e, na segunda etapa, utilizou-se 30mA fixos por gel, durante aproximadamente 5 horas. Em seguida, os géis foram lavados em água destilada deionizada durante 2 minutos e as proteínas foram detectadas por impregnação com prata.

\subsubsection{Detecção das proteínas por impregnação com prata}

A detecção das proteínas foi feita segundo protocolo descrito por Blum et al. (1987), modificado. As soluções foram preparadas imediatamente antes do uso e utilizadas seqüencialmente, conforme descrito a seguir: solução fixadora (50\% metanol; $12 \%$ ácido acético, 0,028\% formaldeído) por 12 horas; três lavagens de 20 minutos cada, com solução $50 \%$ de etanol; solução de sensibilização ( $0,2 \%$ de tiossulfato de sódio) por 1 minuto; três lavagens de 20 
segundos cada com água destilada deionizada; solução de impregnação $(0,2 \%$ nitrato de prata, $0,028 \%$ formaldeído) por 20 minutos; três lavagens de 20 segundos cada com água destilada deionizada; solução reveladora (6\% carbonato de sódio, 0,4\% tiossulfato de sódio, 0,018\% formaldeído) até o aparecimento das proteínas; solução de paralização (5\% de ácido acético) durante 10 minutos.

\subsubsection{Aquisição das imagens e análise dos dados}

As imagens dos géis foram obtidas por varredura, utilizando-se um densitômetro à laser (Personal Densitometer SI, Amersham Bioscience). O Software ImageMaster 2D, versão 3.10 (Amersham Bioscience) foi usado para a detecção dos "spots", calibração do ponto isoelétrico ( $\mathrm{pl}$ ) e da massa molecular aparente, avaliação da abundância relativa das proteínas. As massas moleculares aparentes das proteínas foram determinadas utilizando padrões de massa molecular (Broad Molecular Weight Marker, Sigma). Como padrão de ponto isoelétrico $(\mathrm{pl})$ foram utilizados os dados gerados pela análise do mapa teórico do proteoma total da X. fastidiosa (Laboratório de Química de Proteínas, Instituto de Bioquímica, UNICAMP).

Para a análise do comportamento das proteínas extracelulares em função das temperaturas $\left(28\right.$ e $32^{\circ} \mathrm{C}$ ) e tempos de incubação foram utilizados os dados de abundância (intensidade dos "spots") para geração de gráficos em escalas de cores pelo programa Cluster-Tree View. Também foi feita a análise de agrupamento hierárquico pelo programa Systat, utilizando-se a correlação de Pearson como distância. 


\subsection{Bioensaios para detecção de moléculas sinais difusíveis}

\subsubsection{Bioensaio para detecção de lactonas de homoserina aciladas}

Para determinar se $X$. fastidiosa sintetiza moléculas sinais semelhantes a lactonas de homoserinas aciladas (LHAs), foi utilizado um sistema repórter de Agrobacterium tumefaciens que possui o gene lac $Z$ fundido ao traG, o qual responde à LHAs (Fuqua et al., 1996; Shaw et al., 1997). Este sistema é um dos mais utilizados para a detecção de LHAs, pois é altamente sensitivo a maioria dos tipos de LHAs (Shaw et al., 1997).

Neste ensaio, inoculou-se a linhagem repórter de Agrobacterium tumefaciens NTL4 (pZLR4), em $2 \mathrm{~mL}$ de meio mínimo AB (ANEXO C) suplementado com $0,2 \%$ de glicose e $0,1 \%$ de extrato de levedura, contendo $5 \mu \mathrm{g} \mathrm{mL}^{-1}$ de gentamicina, incubando-se durante 12 horas à $28^{\circ} \mathrm{C}$, com agitação de $150 \mathrm{rpm}$. Também foram preparadas placas de base indicadora contendo meio mínimo $A B$ suplementado com $0,2 \%$ de glicose e $1,5 \%$ de ágar e $40 \mu \mathrm{g} \mathrm{mL}{ }^{-1}$ de X-Gal.

No dia posterior colocou-se $200 \mu \mathrm{L}$ da linhagem repórter NTL4 cultivada durante 12 horas em $10 \mathrm{~mL}$ de meio mínimo $A B$ suplementado com $0,2 \%$ de glicose e $0,1 \%$ de extrato de levedura, contendo $5 \mu \mathrm{gL}^{-1}$ de gentamicina e incubou-se à $28^{\circ} \mathrm{C}$, com agitação de $150 \mathrm{rpm}$. O período de incubação foi de aproximadamente 12 horas, quando a bactéria atinge a fase exponencial de crescimento.

Após a incubação, um volume de $300 \mu \mathrm{L}$ do meio com a bactéria repórter foi retirado e adicionado à $40 \mathrm{~mL}$ de ágar semi-sólido $(0,7 \%$ de ágar em água) contendo $40 \mu \mathrm{g} \mathrm{mL}^{-1}$ de X-Gal. Essa mistura foi vertida sobre a superfície das placas indicadoras, deixando-a solidificar por aproximadamente 10 minutos. Após a solidificação, repicou-se no centro das placas o controle positivo para produção de LHAs, A. tumefaciens $\mathrm{NT}_{1}$ (pTiC58 $\Delta$ accR), o controle negativo de A. tumefaciens $\mathrm{NTL}_{4}$ (pZLR4), e culturas de $X$. campestris pv. campestris, 
$X$. axonopodis pv. citri e $X$. fastidiosa. Cada um dos isolados bacterianos foi colocada separadamente em cada placa. A síntese de LHA é detectada pela produção de uma zona azul difusa ao redor da colônia teste.

\subsubsection{Bioensaio para detecção de DSF}

Para a detecção de moléculas semelhantes ao DSF de $X$. campestris pv. campestris foi utilizado o sistema repórter descrito por Barber et al (1997). Mutantes de $X$. campestris pv. campestris superprodutores de DSF (rpfGHC) foram utilizados como controle positivo. Nos mutantes rpfGHC a expressão dos genes $r p f G, r p f \mathrm{H}$ e $r p f C$ é induzida, fazendo com que eles produzam cerca de 10 vezes mais DSF do que o mutante selvagem. O mutante rpf-" não sintetiza DSF mas responde à adição exógena dessa molécula (Barber et al., 1997). Esse mutante possui um plasmídeo (pL6enggus) contendo GUS fundido ao promotor do gene que codifica uma endoglucanase induzida por DSF (Barber et al., 1997). Essas estirpes foram cultivadas em meio Caldo Nutriente (ANEXO B) por 48 horas à $28^{\circ} \mathrm{C}$.

A X. fastidiosa foi cultivada em meio PW modificado líquido contendo o componente vermelho de fenol $\left(10 \mathrm{~mL} \mathrm{~L}^{-1}\right)$ e incubada à $28^{\circ} \mathrm{C}$ com agitação orbital de $150 \mathrm{rpm}$. No primeiro ensaio, a $X$. fastidiosa foi cultivada durante 16 dias à $28^{\circ} \mathrm{C}$ para extração da molécula sinal putativa. No segundo ensaio, a extração foi feita aos 4, 8, 12, 16 e 20 após a adição do inóculo de $X$. fastidiosa.

Para extração de DSF, em tubos cônicos esterilizados foram colocados $25 \mathrm{~mL}$ de sobrenadantes acelulares de cada cultivo bacteriano e 0,3 volume de acetato de etila, previamente equilibrado com bicarbonato de sódio. A mistura foi agitada durante 50 minutos à temperatura ambiente. $O$ extrato em acetato de etila foi removido após breve centrifugação, conforme metodologia descrita por Barber et al. (1997). Os extratos foram secos em evaporador rotatório e usados nos bioensaio para detecção de DSF. 
Foram preparados extratos dos meios Caldo Nutriente e PW modificado contendo o vermelho de fenol, sem o cultivo bacteriano, para serem usados como controles negativos.

Os extratos das culturas bacterianas ou dos meios sem o crescimento bacteriano (controles negativos), foram ressuspendidos em $200 \mu \mathrm{L}$ de água destilada desionizada e o bioensaio, baseado na recuperação da atividade da endoglucanase pelo mutante rpfF' de $X$. campestris pv. campestris, foi realizado conforme descrito por Barber et al. (1997).

Uma alíquota de $100 \mu \mathrm{L}$ do extrato foi adicionada à microtubos esterilizados contendo $900 \mu \mathrm{L}$ de meio MMXC (ANEXO D) e $100 \mu \mathrm{L}$ do meio MMXC (ANEXO D) contendo a bactéria repórter $X$. campestris pv. campestris rpfF (pL6enggus), durante 12 horas à $29^{\circ} \mathrm{C}$ com agitação orbital de $150 \mathrm{rpm}$. A cultura foi incubada à $32^{\circ} \mathrm{C}$ durante 24 horas. Após esse período, os microtubos foram centrifugados à $5.000 \mathrm{~g}$ durante 10 minutos e o sobrenadante foi transferido para microtubos esterilizados. Um volume de $40 \mu \mathrm{L}$ de cada sobrenadante foi colocado em poços feitos em placas com meio CMC-ágar (ANEXO D) e incubado por 24 horas à $32^{\circ} \mathrm{C}$. A atividade de endoglucanase foi determinada pela degradação da carboximetilcelulose. As placas foram tratadas com $5 \mathrm{~mL}$ de uma solução de vermelho de Congo $(0,1 \%)$, por 20 minutos à temperatura ambiente e posteriormente foram lavadas com $\mathrm{NaCl}$. A atividade da endoglucanase pode ser observada pela formação de uma zona de hidrólise no substrato, resultando num halo amarelado em fundo vermelho.

A quantificação de DSF produzido por $X$. fastidiosa durante 0 crescimento foi feita tendo com base uma curva padrão de DSF produzido por $X$. campestris pv. campestris superprodutor de DSF (rpfGHC).

Para identificar e purificar o DSF produzido por $X$. fastidiosa, análises de extratos por cromatografia líquida de alta precisão (HPLC) em fase reversa foram realziadas. Os extratos foram analisados utilizando-se um gradiente de 
água-acetonitrila/TFA 0,1\% (0-100\%), em coluna Supelcosil LC18 (Supelco). O eluente foi monitorado à $210 \mathrm{~nm}$.

O DSF de $X$. campestris pv. campestris rpfGHC e de $X$. fastidiosa foram extraídos como descrito acima e ressolubilizados em $200 \mu \mathrm{L}$ de água destilada deionizada. Como controles negativos, utilizou-se o extrato dos meios Caldo Nutriente e PW modificado líquido contendo vermelho de fenol, sem o crescimento bacteriano. Os perfis de moléculas eluídas foram comparados. 


\section{RESULTADOS E DISCUSSÃO}

\subsection{Confirmação da identidade do isolado utilizado nos experimentos}

Na Figura 1 pode-se observar o resultado da extração do DNA total da bactéria. O protocolo utilizado proporcionou bom rendimento e DNA de boa qualidade. Os resultados indicam a presença do DNA cromossômico de alta massa molecular e dos plasmídeos pXF51 e pXF1.3.

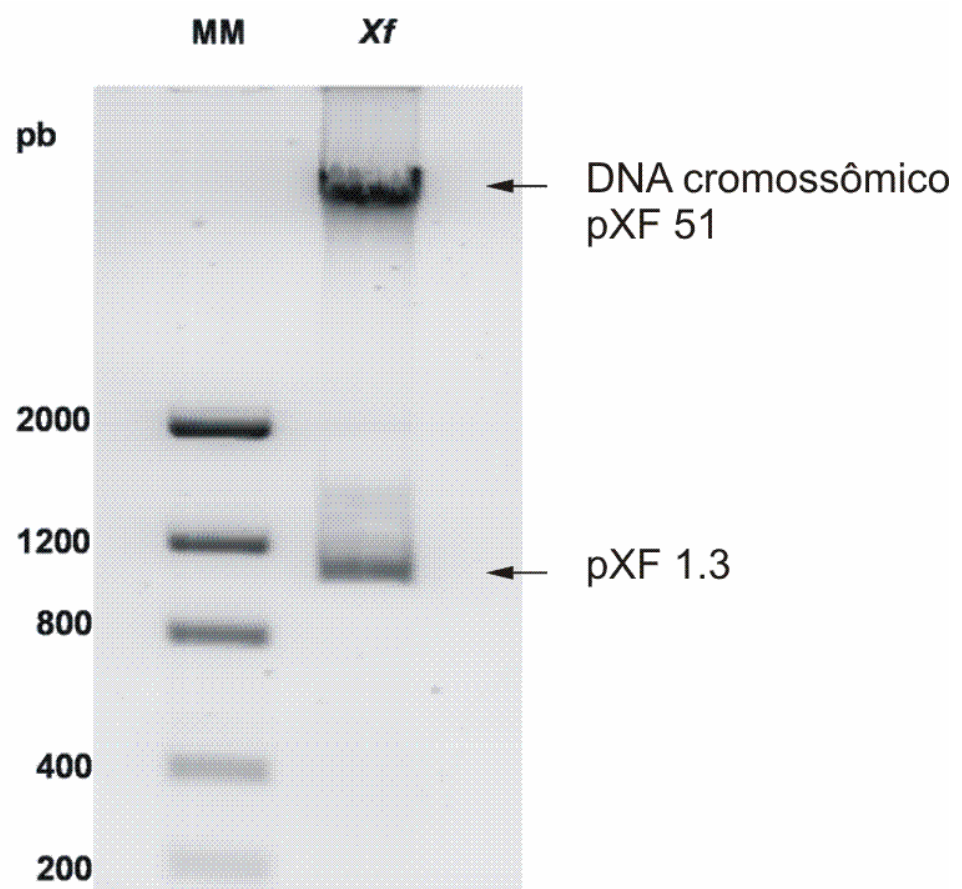

Figura 1 - DNA total de $X$. fastidiosa extraído de células cultivadas em meio PW modificado. MM: marcador molecular. Xf: DNA de $X$. fastidiosa. 
Na Figura 2 pode-se observar o produto da amplificação do DNA de $X$. fastidiosa por PCR, com uso dos iniciadores CVC1 e CVC272-int, específicos para $X$. fastidiosa. A amplificação do DNA com esse par de iniciadores resultou no fragmento esperado de 500pb.

O uso de amplificações de seqüências específicas do DNA, através da técnica de PCR, permite que isolados bacterianos sejam diferenciados e caracterizados genotipicamente. Neste caso, a caracterização genética do isolado de $X$. fastidiosa usado nos experimentos, através de PCR com oligonucleotídeos específicos (CVC1 e CVC272-int), confirmou a identidade da bactéria utilizada nos experimentos.

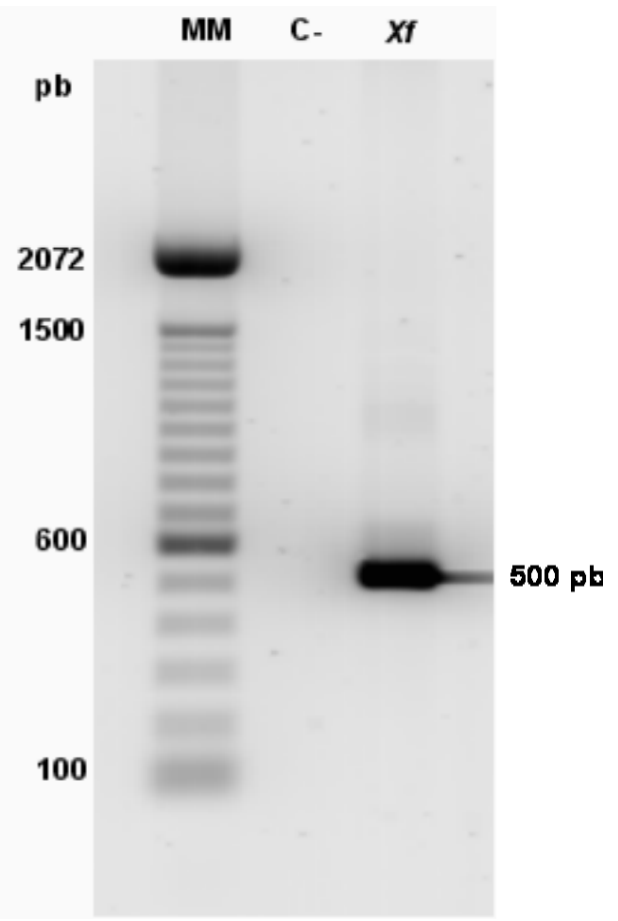

Figura 2 - Produto da amplificação do DNA de $X$. fastidiosa por PCR, com os iniciadores CVC1 e CVC272-int. MM: marcador molecular. C-: Controle negativo (sem DNA). Xf: produto da amplificação do DNA total de $X$. fastidiosa. 


\subsection{Monitoramento do crescimento de $X$. fastidiosa à 28 e $32^{\circ} \mathrm{C}$}

A avaliação dos efeitos de diferentes temperaturas no crescimento e na sobrevivência de fitopatógenos in vitro pode fornecer conhecimentos básicos para os estudos da fisiologia microbiana e subsidiar hipótese para explicar os mecanismos que regulam a interação planta-microrganismo.

A maior severidade dos sintomas da CVC tem sido associada à temperaturas mais elevadas. Desta forma, o conhecimento dos efeitos da temperatura no crescimento da bactéria in vitro pode nos dar informações adicionais sobre o comportamento da bactéria e ajudar a traçar o perfil epidemiológico da doença, visando o seu controle.

$\mathrm{O}$ crescimento da bactéria em meio PW modificado líquido à 28 e $32^{\circ} \mathrm{C}$, durante 16 dias, com base na turbidez do meio, medida pela absorbância à $600 \mathrm{~nm}\left(\mathrm{~A}_{600}\right)$, pode ser visto na Figura 3.

Constatou-se que a retirada do componente albumina de soro bovino (ASB) da composição original do meio $\mathrm{PW}$, não alterou o crescimento da bactéria. Quanto ao vermelho de fenol, a sua retirada da composição original do meio PW evitou o escurecimento das células durante o crescimento da bactéria, facilitando as determinações de $A_{600}$, e facilitando a extração de proteínas do meio de cultivo. 


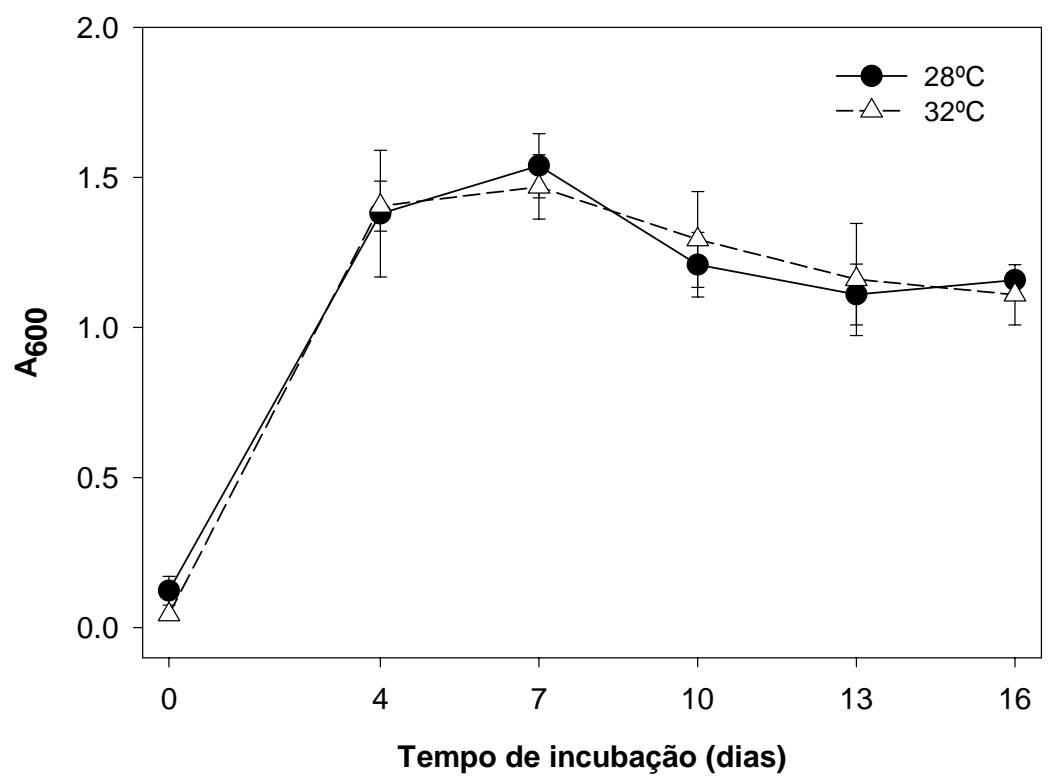

Figura 3 - Crescimento de $X$. fastidiosa em meio PW modificado líquido à $28 \mathrm{e}$ $32^{\circ} \mathrm{C}$, com base na absorbância à $600 \mathrm{~nm}\left(\mathrm{~A}_{600}\right)$. Os dados são médias de 3 repetições \pm desvio padrão da média.

Observa-se que a fase logarítmica de crescimento de $X$. fastidiosa à 28 e $32^{\circ} \mathrm{C}$, estendeu-se até aproximadamente 7 dias (Figura 3). A partir de 7 dias de incubação, a cultura entrou na fase estacionária e, posteriormente, na fase de declínio. Após 10 dias de incubação à 28 e $32^{\circ} \mathrm{C}$, houve um decréscimo significativo $(p<0,05)$ no crescimento em relação aos 7 dias (máximo), indicando que a bactéria atingiu a fase de declínio.

Não houve diferença significativa $(p \geq 0,05)$ no crescimento de X. fastidiosa avaliado através da $A_{600}$ à 28 e $32^{\circ} \mathrm{C}$.

A avaliação da turbidez do meio é uma medida amplamente utilizada nos estudos de crescimento bacteriano. Porém, procurou-se utilizar outras variáveis que podem informar sobre o crescimento bacteriano, como a viabilidade celular e número de unidades formadoras de colônias (UFC).

Vários estudos têm sido realizados utilizando corantes fluorescentes para avaliar a viabilidade celular de microrganimos. Os ensaios baseados em corantes fluorescentes tendem a substituir o cultivo clássico de microrganismos 
em substratos agarizados, o qual tem sido um procedimento de referência para a estimativa do número de bactérias cultiváveis. Esses novos ensaios tornam possível a avaliação não somente das células cultiváveis, mas também daquelas células viáveis mas não cultiváveis (VMNC), as quais são caracterizadas pela manutenção da atividade metabólica mas com redução no crescimento em meio sólido (Decker, 2001).

A viabilidade de $X$. fastidiosa cultivada em meio PW modificado líquido à 28 e $32^{\circ} \mathrm{C}$, durante 16 dias, pode ser observada na Figura 4.

Os resultados obtidos mostram que a porcentagem de células viáveis de $X$. fastidiosa foi máxima (100\%) aos 7 dias de incubação à 28 e $32^{\circ} \mathrm{C}$. Aos 10 dias de cultivo à $32^{\circ} \mathrm{C}$, a viabilidade celular diminuiu para $95 \%$, mantendo-se em $90 \%$ após 16 dias de cultivo. Aos 10 dias de cultivo à $28^{\circ} \mathrm{C}$, a viabilidade celular diminuiu para 93\%, aumentando para 95\% aos 16 dias.

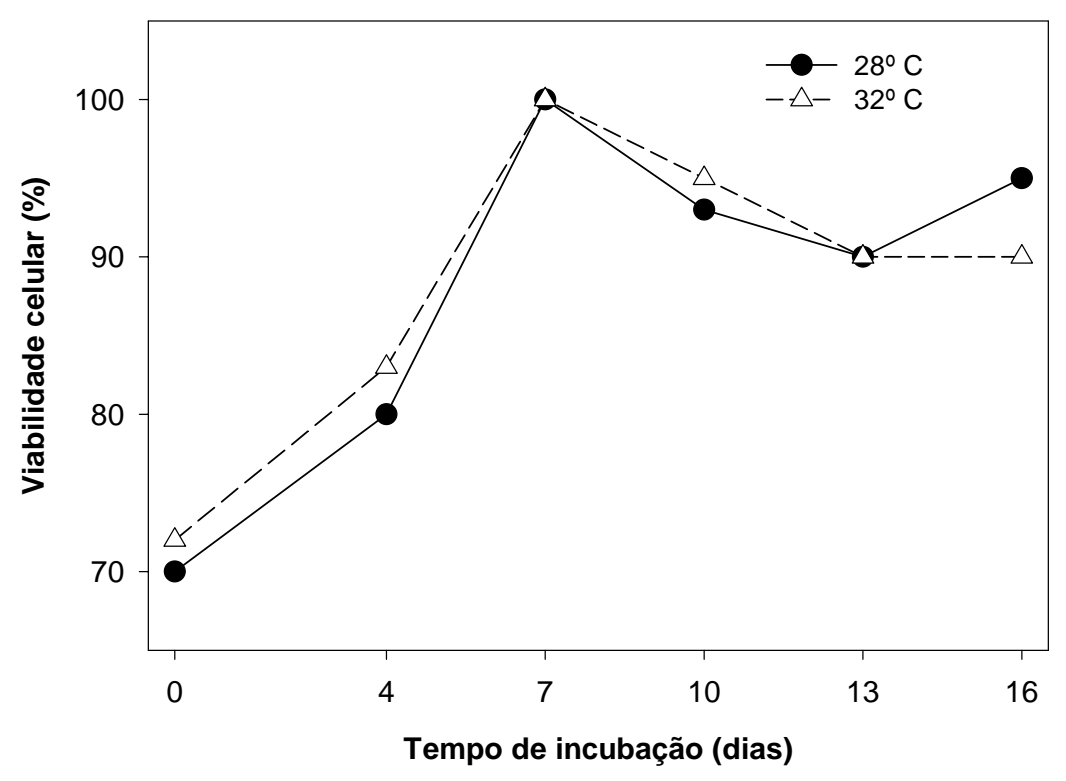

Figura 4 - Viabilidade de $X$. fastidiosa em meio PW modificado líquido à 28 e $32^{\circ} \mathrm{C}$. Os dados são médias de 3 repetições \pm desvio padrão da média. 
Houve diferença significativa $(p \leq 0,05)$ na viabilidade celular de $X$. fastidiosa em função das temperaturas $\left(28\right.$ e $32^{\circ} \mathrm{C}$ ), dos tempos de incubação e da interação desses fatores. Somente não foram significativas as diferenças na viabilidade celular aos 7 e 13 dias de incubação à 28 e $32^{\circ} \mathrm{C}$.

Portanto, no início da fase logarítmica de crescimento (4 dias), a viabilidade celular foi maior à $32^{\circ} \mathrm{C}$ do que à $28^{\circ} \mathrm{C}$, indicando um maior crescimento da bactéria à temperatura mais elevada. Porém, na fase de declínio (16 dias), a viabilidade celular foi maior à 28 do que à $32^{\circ} \mathrm{C}$, indicando menor crescimento.

Após 7 dias de incubação, houve redução na viabilidade celular tanto à 28 quanto à $32^{\circ} \mathrm{C}$. Em E. coli, foram observadas reduções graduais na viabilidade celular na fase estacionária de crescimento (Kolter et al., 1993).

Ensaios de viabilidade celular tem sido utilizados paralelamente com a técnica de contagem do número de colônias bacterianas em meios de cultivo agarizados. Decker et al. (2001) mostraram que ensaios de viabilidade com os corantes Syto 9/Propidium iodine (PI), são ferramentas apropriadas para Streptococcus sanguinis e S. mutans, pois métodos convencionais baseados na habilidade de multiplicação das células podem subestimar o número de células viáveis devido a formação de biofilme pela bactéria.

$\mathrm{O}$ crescimento da bactéria em meio $\mathrm{PW}$ modificado líquido à 28 e $32^{\circ} \mathrm{C}$, durante 16 dias, com base na contagem do número de unidades formadoras de colônias (UFC), pode ser visto na Figura 5. 


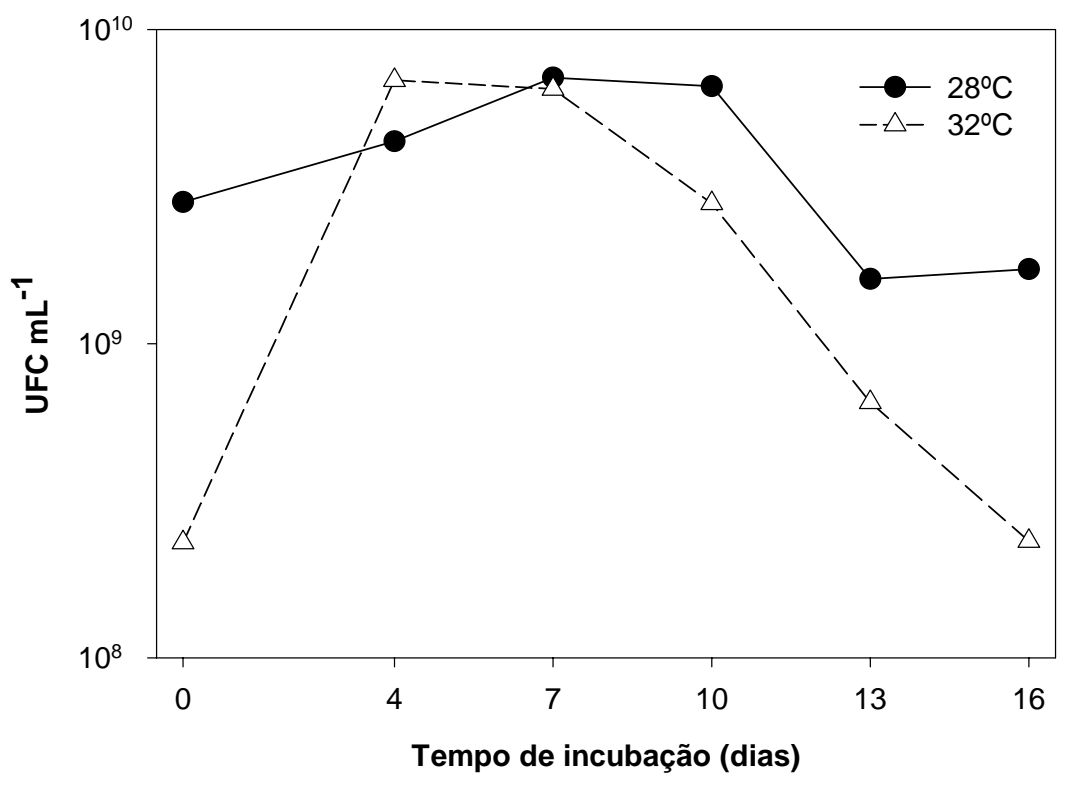

Figura 5 - Crescimento de $X$. fastidiosa em meio $\mathrm{PW}$ modificado agarizado à 28 e $32^{\circ} \mathrm{C}$, com base no número de unidades formadoras de colônias (UFC). Os dados são médias de 3 repetições \pm desvio padrão da média.

Observa-se um rápido aumento da população de $X$. fastidiosa até 4 dias de cultivo à $32^{\circ} \mathrm{C}$, sendo que após 7 dias, a população diminuiu progressivamente. Após 4 dias de crescimento da bactéria à $32^{\circ} \mathrm{C}$, o número de UFC foi cerca de 1,5 vezes maior do que o número de UFC à $28^{\circ} \mathrm{C}$, apesar do inóculo inicial utilizado no tempo zero ser 12 vezes menor no ensaio à 32 do que à $28^{\circ} \mathrm{C}$. Aos 10 e 13 dias de incubação à $32^{\circ} \mathrm{C}$, o número de UFC foi cerca de 2,3 vezes menor do que o número de UFC à $28^{\circ} \mathrm{C}$. Aos 16 dias de incubação à $32^{\circ} \mathrm{C}$, o número de UFC diminuiu cerca de 7,3 vezes em relação ao número de UFC à $28^{\circ} \mathrm{C}$.

Quanto à temperatura de $28^{\circ} \mathrm{C}$, os dados mostram que o número de UFC da $X$. fastidiosa aumentou até o $7^{\circ}$ dia de cultivo, diminuindo após 10 dias de cultivo.

Houve diferença significativa $(p \leq 0,05)$ no crescimento de $X$. fastidiosa avaliado através do número de UFC, em função das temperaturas $\left(28\right.$ e $\left.32^{\circ} \mathrm{C}\right)$, 
dos tempos de incubação utilizados no experimento e das interações entre esses fatores.

Comparando-se os resultados de contagem do número de UFC e viabilidade celular à 28 e $32^{\circ} \mathrm{C}$, é possível que a redução no número de UFC após 7 dias de cultivo da bactéria à $32^{\circ} \mathrm{C}$, ocorreu devido à entrada das bactérias no estado viável mas não cultivável (VMNC), pois a viabilidade celular foi significativamente maior à 32 do que à $28^{\circ} \mathrm{C}$, até a fase de declínio.

Almeida et al. (2001) observaram uma redução da população de células cultiváveis de $X$. fastidiosa, quando comparadas com a população bacteriana em plantas de videira com o mal de Pierce. Esses autores explicaram o fato sugerindo que a maioria das células de $X$. fastidiosa no interior das plantas de citros sintomáticas poderiam estar mortas.

É possível que as células de $X$. fastidiosa crescendo em biofilmes, sob condições de temperatura mais elevada $\left(32^{\circ}\right)$, não sejam cultiváveis no meio de cultura utilizado, após a entrada na fase estacionária, pois entrariam mais rapidamente no estado VMNC, do que sob condições de temperaturas mais baixa $\left(28^{\circ} \mathrm{C}\right)$. Tem sido observado que bactérias em biofilmes maduros podem permanecer no estado VMNC, diminuindo sua atividade metabólica (Decker, 2001).

A indução do estado VMNC tem sido vista como uma estratégia de sobrevivência ativada durante a fase estacionária de crescimento bacteriano e/ou a privação de nutrientes, embora sob condições favoráveis de crescimento a bactéria terá a habilidade de reverter este processo e multiplicar-se (Oliver, 1995). Contrariamente, outros autores argumentam que o estado VMNC pode ser uma condição em que a célula está com sinais reduzidos de atividade metabólica mas são incapazes de multiplicarem-se, tornando-se progressivamente debilitada até que ocorra a morte celular (McDouglad et al., 1998). 
Populações de bactérias no ambiente estão freqüentemente expostas a estresses devido a limitações e modificações na disponibilidade de nutrientes, temperatura, salinidade, exposição solar e saturação de oxigênio. A persistência da bactéria no ambiente é em grande parte determinada por sua habilidade para tolerar os estresses a que for submetida.

A entrada na fase estacionária de crescimento altera drasticamente os padrões de expressão gênica, permitindo prolongar a sobrevivência bacteriana na ausência de nutrientes. Em B. subtilis, a sobrevivência é mediada pela formação de esporos de resistência. Para bactérias não-esporulantes, como E. coli, a fase estacionária resulta no aumento da resistência a inúmeros estresses ambientais, como osmolaridade, agentes oxidantes e temperaturas (Dong et al., 2001). Em Vibrio vulnificus, a exposição a temperaturas baixas durante a fase estacionária de crescimento, induz o estado VMNC, enquanto que à temperatura ambiente ocorre uma clássica resposta de privação de nutrientes (Weichart et al., 1992).

É possível que a uma temperatura mais elevada $\left(32^{\circ} \mathrm{C}\right)$ e sob baixa quantidade de inóculo, a $X$. fastidiosa inicialmente seja induzida a se multiplicar mais rapidamente até atingir a fase de crescimento estacionário e ativar os genes para formação de biofilme. O biofilme poderá proteger as células durante a privação de nutrientes e temperatura mais elevada. Como as condições do ambiente in vitro não se modificaram, as células continuariam no estado VMNC.

Tem sido proposto que a viabilidade pode ser mantida na ausência de culturabilidade e que o estado VMNC é análogo às respostas de estresses, como as respostas de diferenciação celular que ocorrem em certas bactérias. Desta forma, o estado VMNC pode ser uma resposta fisiológica geneticamente programada de algumas bactérias, permitindo o aumento da sobrevivência durante a ocorrência de estresse ambiental e retorno da atividade metabólica normal sob condições favoráveis (McDouglad et al., 1998). 
McDouglad et al. (1998) propuseram que existem duas fases para a formação de células VMNC. Na primeira há uma transição para o estado de VMNC, onde ocorre a perda de culturabilidade da célula, enquanto são mantidos intactos a integridade celular e dos ácidos nucléicos. Na segunda fase, há a perda gradual da integridade celular e, posteriormente, ocorre a degradação do RNA e do DNA, levando à perda da viabilidade. Tem sido observado em nosso laboratório uma maior degradação do RNA total de $X$. fastidiosa em cultivos na fase estacionária, quando comparada à cultivos na fase exponencial (dados não publicados).

Feil \& Purcell (2001) verificaram que o pico da população de células da estirpe de $X$. fastidiosa causadora do mal de Pierce ocorreu após 6 dias de cultivo da bactéria no meio $\mathrm{PW}$ aos $28^{\circ} \mathrm{C}$, o que é similar ao que ocorreu em nossos experimentos. Entretanto, após 3 dias de cultivo, os autores observaram populações 20 vezes menores à $32^{\circ} \mathrm{C}$ do que à $28^{\circ} \mathrm{C}$. Nossos dados mostram que mesmo com inóculo inicial 12 vezes menor, as células cultivadas à $32^{\circ} \mathrm{C}$ conseguiram superar o crescimento à $28^{\circ} \mathrm{C}$, após 4 dias de cultivo. Assim, a estirpe de $X$. fastidiosa causadora da CVC parece ter uma maior adaptação à temperatura de $32^{\circ} \mathrm{C}$ do que a estirpe causadora do mal de Pierce.

Segundo esses autores, o limite de temperatura para o crescimento da estirpe de $X$. fastidiosa causadora do mal de Pierce, in planta, está entre 17$25^{\circ} \mathrm{C}$, sendo possível que em condições de campo a bactéria não se multiplique durante noites frias ou à temperatura abaixo de $17^{\circ} \mathrm{C}$. Assim, em regiões com baixa variação entre temperaturas diurnas e noturnas, haverá uma menor interrupção na fase exponencial, e conseqüentemente, o crescimento da bactéria in planta será mais rápido do que em regiões com maiores variações entre temperaturas diurnas e noturnas.

Nas regiões do Estado de São Paulo onde é verificado uma maior severidade dos sintomas da CVC, as temperaturas são mais elevadas. Então, é 
possível que a estirpe de $X$. fastidiosa causadora da CVC beneficie-se de temperaturas mais elevadas para o crescimento inicial da bactéria in planta.

Como os sintomas da CVC demoram para serem observados na planta após a infecção de $X$. fastidiosa, é possível que a temperatura alta induza a multiplicação celular inicial, logo após a entrada da bactéria no xilema da planta, favorecendo a formação de biofilmes e propiciando uma estratégia de sobrevivência para a bactéria neste ambiente. Porém, quando da maturação do biofilme, a temperatura elevada desencadearia sinais específicos para a entrada no estado VMNC mais rapidamente do que em temperaturas mais baixas. Desta forma, no estado VMNC, fragmentos do biofilmes poderiam desprender-se das paredes do xilema e bloquear os vasos condutores, contribuindo para o desenvolvimento dos sintomas da CVC.

\subsection{Análise do proteoma extracelular de $X$. fastidiosa cultivada em meio PW modificado líquido}

A grande quantidade de informações resultantes do seqüenciamento genético de $X$. fastidiosa possibilitou a formulação de várias hipóteses sobre os mecanismos de patogenicidade bacteriana. Dentre estas hipótese, tem sido sugerido que fatores de patogenicidade/virulência extracelulares poderiam ter papel importante no desenvolvimento da CVC.

A análise do proteoma extracelular de $X$. fastidiosa em meio PW modificado líquido poderia ser útil na identificação de proteínas com acúmulo diferencial durante o crescimento da bactéria, as quais poderiam estar envolvidas no desenvolvimento da CVC.

Nas Figuras 6 à 10 pode-se observar o perfil protéico extracelular de $X$. fastidiosa cultivada em meio PW modificado líquido à 28 e $32^{\circ} \mathrm{C}$, durante 16 dias de crescimento. 


\section{4 dias}

$28^{\circ} \mathrm{C}$

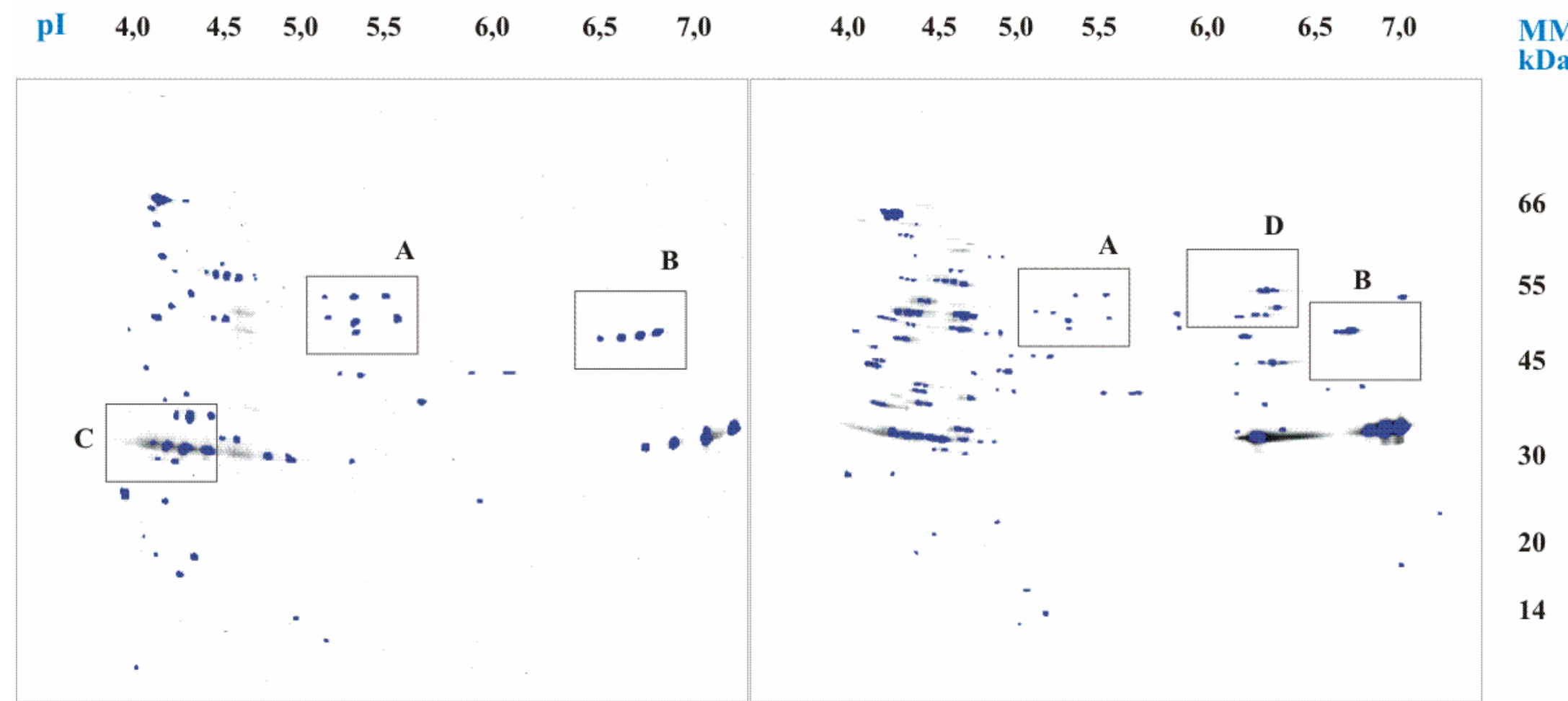

Figura 6 - Eletroforese bidimensional de proteínas extracelulares de $X$. fastidiosa 9a5c cultivada em meio PW modificado líquido à 28 e $32^{\circ} \mathrm{C}$, após 4 dias de incubação. Quantidades iguais de proteína $(100 \mu \mathrm{g})$ foram utilizadas nos diferentes géis. A, B, C e D, áreas dos géis de proteínas analisadas em detalhe. pl: ponto isoelétrico. MM: marcador molecular. 


\section{7 dias}

$28^{\circ} \mathrm{C}$

$32^{\circ} \mathrm{C}$

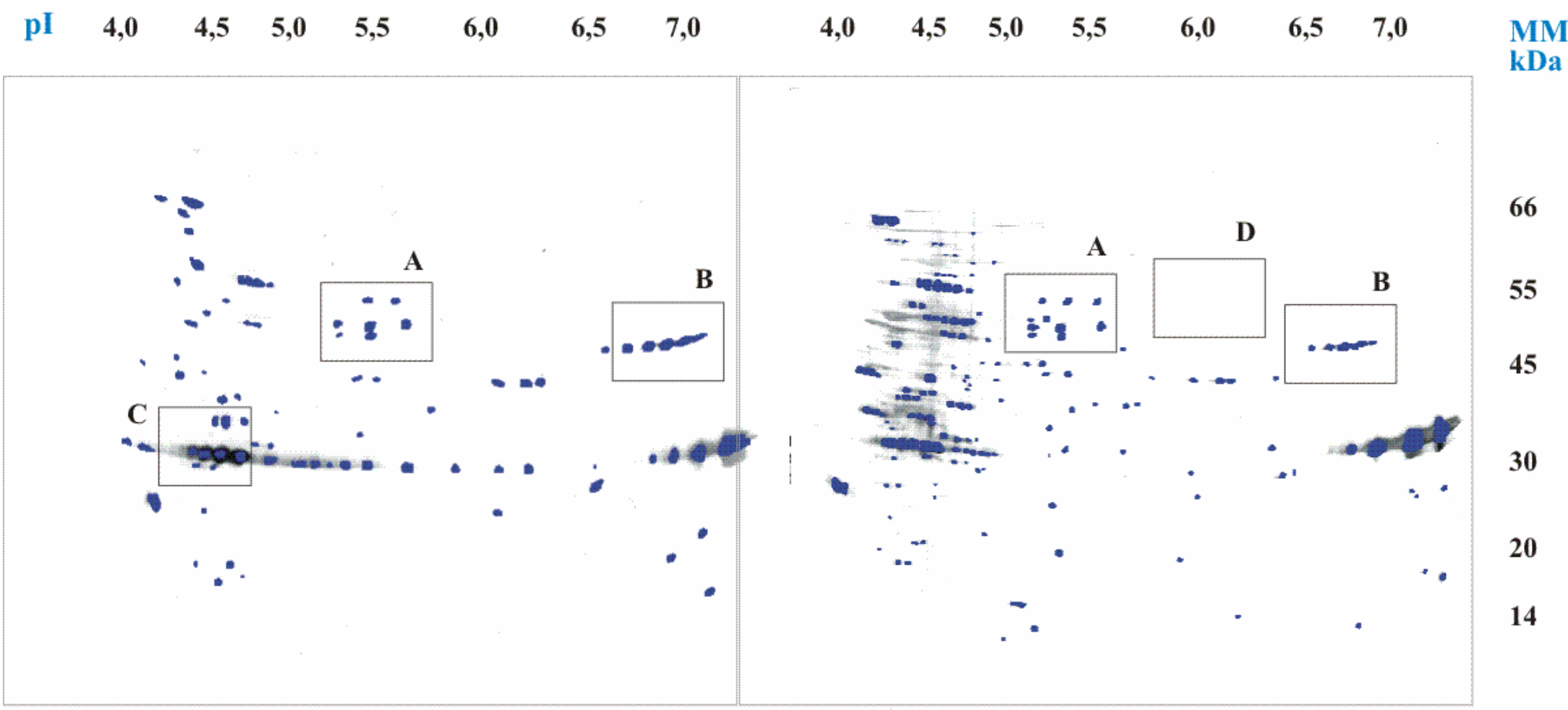

Figura 7 - Eletroforese bidimensional de proteínas extracelulares de $X$. fastidiosa 9a5c cultivada em meio PW modificado líquido à 28 e $32^{\circ} \mathrm{C}$, após 7 dias de incubação. Quantidades iguais de proteína $(100 \mu \mathrm{g})$ foram utilizadas nos diferentes géis. A, B, C e D, áreas dos géis de proteínas analisadas em detalhe. pl: ponto isoelétrico. MM: marcador molecular. 


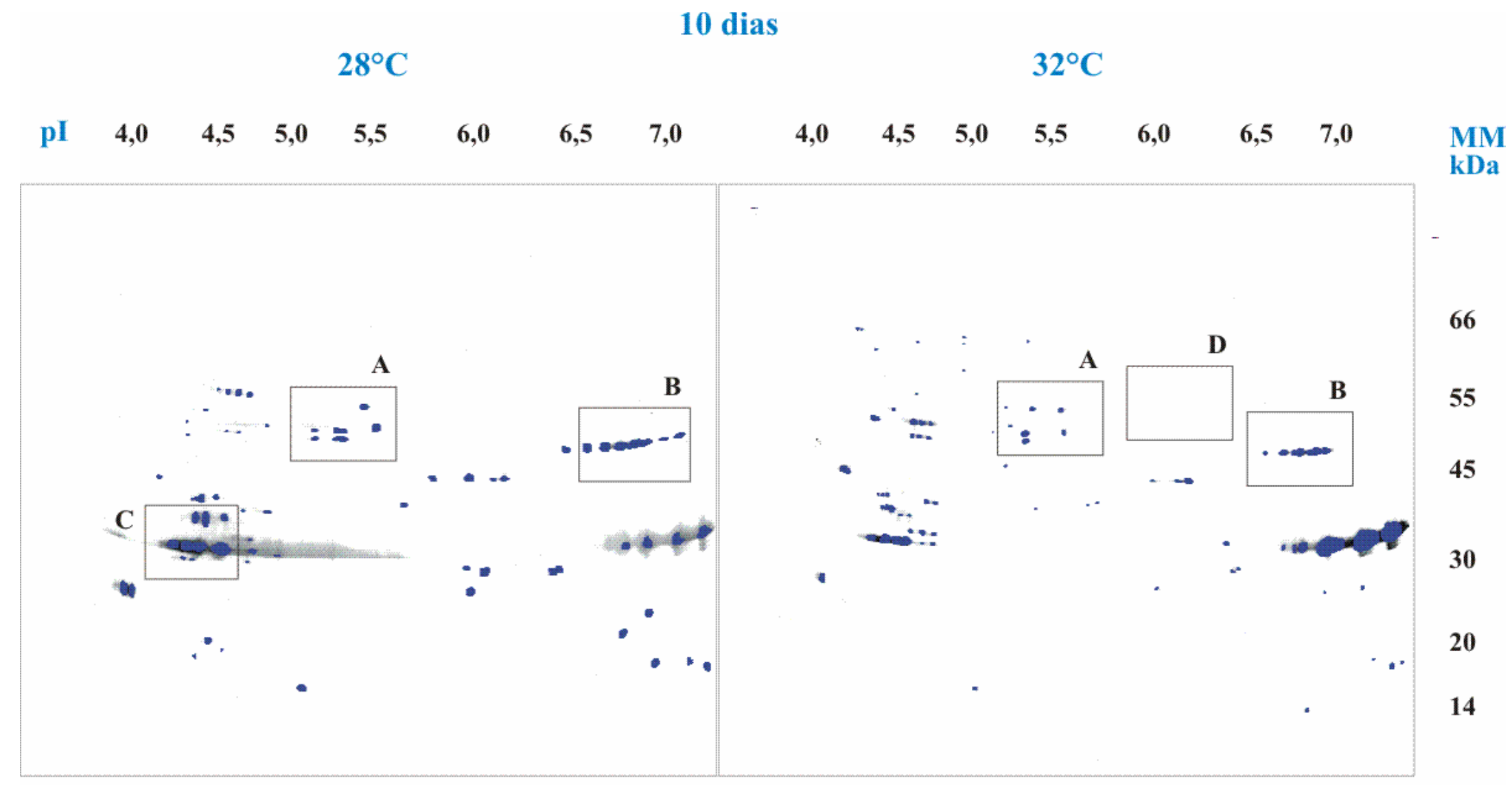

Figura 8 - Eletroforese bidimensional de proteínas extracelulares de $X$. fastidiosa 9a5c cultivada em meio PW modificado líquido à 28 e $32^{\circ} \mathrm{C}$, após 10 dias de incubação. Quantidades iguais de proteína (100 $\left.\mu \mathrm{g}\right)$ foram utilizadas nos diferentes géis. A, B, C e D, áreas dos géis de proteínas analisadas em detalhe. pl: ponto isoelétrico. MM: marcador molecular. 


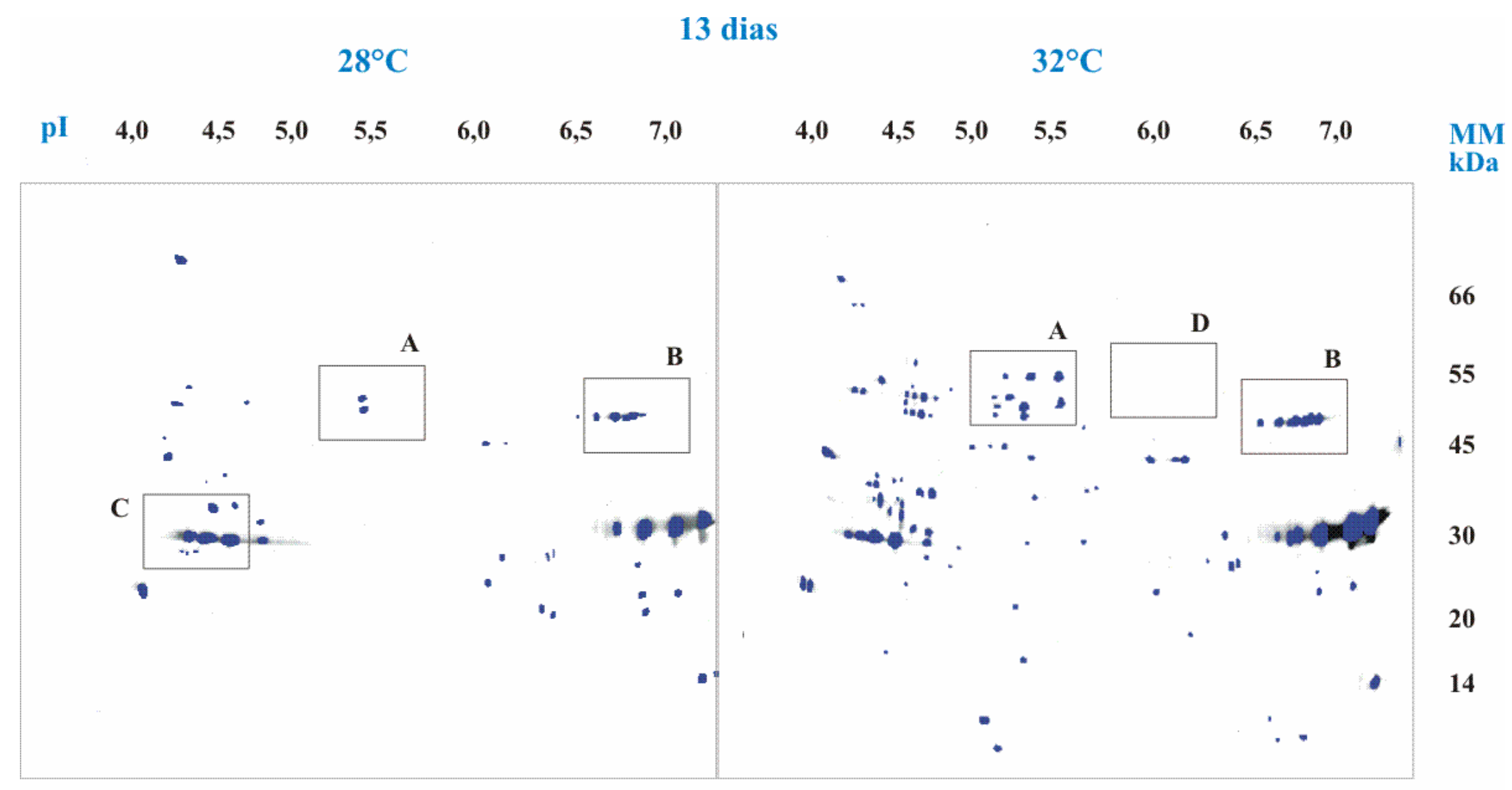

Figura 9 - Eletroforese bidimensional de proteínas extracelulares de $X$. fastidiosa 9a5c cultivada em meio PW modificado líquido à 28 e $32^{\circ} \mathrm{C}$, após 13 dias de incubação. Quantidades iguais de proteína (100 $\left.\mu \mathrm{g}\right)$ foram utilizadas nos diferentes géis. A, B, C e D, áreas dos géis de proteínas analisadas em detalhe. pl: ponto isoelétrico. MM: marcador molecular. 


\section{6 dias}

$28^{\circ} \mathrm{C}$

$32^{\circ} \mathrm{C}$

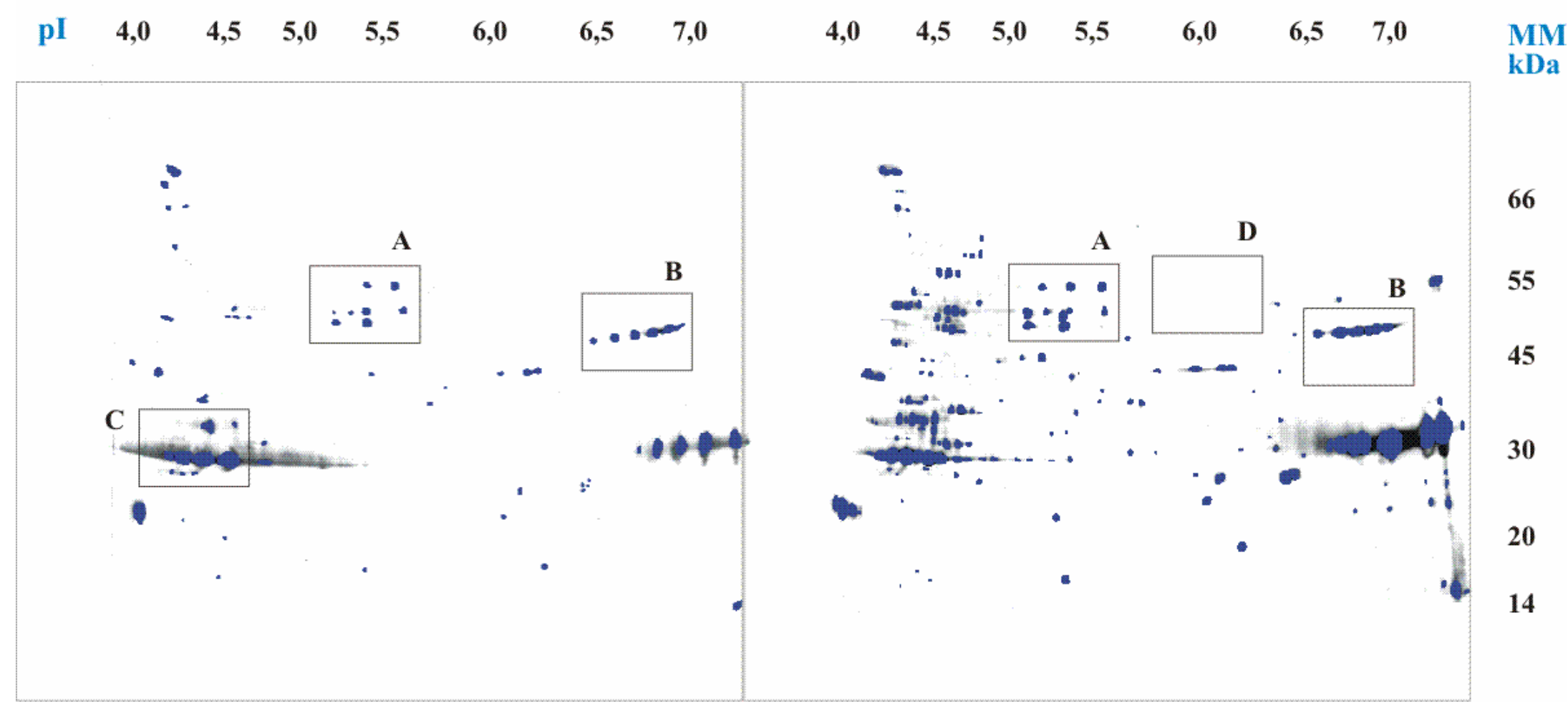

Figura 10 - Eletroforese bidimensional de proteínas extracelulares de $X$. fastidiosa 9a5c cultivada em meio PW modificado líquido à 28 e $32^{\circ} \mathrm{C}$, após 16 dias de incubação. Quantidades iguais de proteína $(100 \mu \mathrm{g})$ foram utilizadas nos diferentes géis. A, B, C e D, áreas dos géis de proteínas analisadas em detalhe. pl: ponto isoelétrico. MM: marcador molecular. 
Constatou-se que a retirada do componente albumina de soro bovino da composição original do meio $\mathrm{PW}$, favoreceu a resolução de proteínas extracelulares através da eletroforese em géis de poliacrilamida. Este fato havia sido evidenciado por Cordwell et al. (2001), os quais relataram que os meios de cultivo contendo $A B S$, requeridos por alguns organismos fastidiosos, contém níveis elevados de contaminantes que afetam a técnica de 2D-PAGE. Quanto ao vermelho de fenol, a sua retirada da composição original do meio PW impediu o escurecimento do meio conforme o crescimento da bactéria, facilitando a extração de proteínas secretadas.

$\mathrm{O}$ maior número de proteínas extracelulares produzidas à $28^{\circ} \mathrm{C}$ foi observado aos 7 (82 proteínas; Figura 11). O menor número de proteínas secretadas à $28^{\circ} \mathrm{C}$ foi observado aos 13 dias de incubação (49 proteínas).

$\mathrm{O}$ maior número de proteínas extracelulares produzidas à $32^{\circ} \mathrm{C}$ foi observado aos 16 dias de incubação (160 proteínas; Figura 11). O menor número de proteínas secretadas à $32^{\circ} \mathrm{C}$ foi observado aos 10 dias de incubação (76 proteínas).

A maior parte das proteínas extracelulares produzidas por $X$. fastidiosa (Figura 6 à 10) foram detectadas na região com pl variando entre 4,0-5,5 e massa molecular aparente entre 20-60 kDa. Assim, em meio de cultivo PW modificado líquido, a maioria da proteínas secretadas por $X$. fastidiosa foram proteínas ácidas e de baixa massa molecular.

Comparando-se o crescimento de $X$. fastidiosa à $28^{\circ} \mathrm{C}$ (Figuras $6-10$ ) e a produção de proteínas extracelulares (Figura 11), observa-se um acúmulo de proteínas até os 7 dias de incubação, coincidindo com a fase logarítmica de crescimento. Após esse período, a bactéria provavelmente entrou na fase estacionária de crescimento, diminuindo a produção de proteínas, com produção mínima aos 13 dias de incubação. Aos 16 dias de crescimento, houve aumento da produção de proteínas extracelulares. 
Comparando-se o crescimento de $X$. fastidiosa à $32^{\circ} \mathrm{C}$ (Figuras 6 -10) e a produção de proteínas extracelulares (Figura 11), verifica-se um comportamento semelhante ao que ocorreu à $28^{\circ} \mathrm{C}$. Entretanto, à $32^{\circ} \mathrm{C}$, houve novamente um acúmulo de proteínas extracelulares aos 13 dias, o qual foi máximo aos 16 dias de incubação.

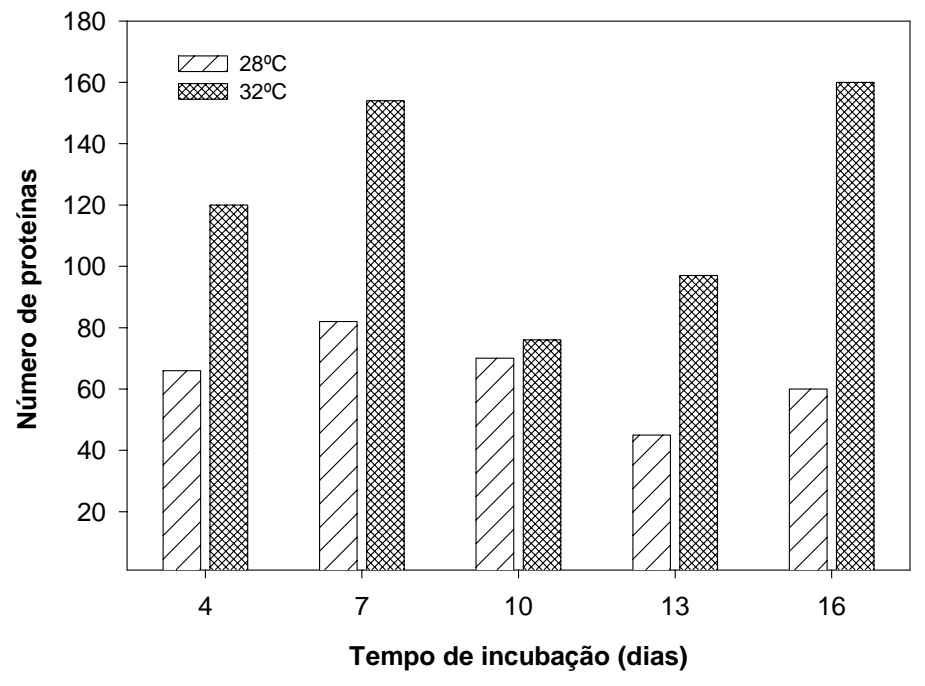

Figura 11 - Número de proteínas extracelulares produzidas por $X$. fastidiosa em meio $\mathrm{PW}$ modificado líquido à 28 e $32^{\circ} \mathrm{C}$.

Tem sido relatado que as bactérias durante a fase estacionária e/ou privação de nutrientes, não interrompem a atividade metabólica ou param simplesmente o seu crescimento (Wai et al., 1999). As bactérias realizam atividades induzidas pela privação de nutrientes e/ou fase estacionária, as quais incluem a produção de proteases e lipases, e de enzimas envolvidas na aquisição de nutrientes, como a glutamina sintetase e fosfatase alcalina. Além disso, durante a privação de nutrientes as bactérias podem se diferenciar em um estado mais resistente, a fim de manter a viabilidade celular durante este período (Wai et al., 1999).

Os resultados mostram que $X$. fastidiosa crescendo à $32^{\circ} \mathrm{C}$ tem maior capacidade para secretar proteínas do que à $28^{\circ} \mathrm{C}$. Como os sintomas da CVC 
são mais severos em regiões de clima mais quente, é possível que os fatores de patogenicidade/virulência secretados à $32^{\circ} \mathrm{C}$, e não à $28^{\circ} \mathrm{C}$, sejam essenciais para o desenvolvimento da CVC.

Recentemente foi publicado o mapa de referência das proteínas produzidas por $X$. fastidiosa 9a5c. Nesse trabalho foi avaliado o proteoma total e extracelular de $X$. fastidiosa 9a5c isolada de citros, através de eletroforese em gel bidimensional (2D-PAGE), unidimensional (SDS-PAGE) e espectrometria de massa. Foram identificados produtos de 142 genes presentes no extrato celular total e numa fração extracelular dessa estirpe cultivada em meio sólido BCYE durante 21 dias (Smolka et al. 2003). Comparando-se o perfil protéico extracelular obtido por Smolka et al. (2003) e das proteínas extracelulares obtidas à 28 e $32^{\circ} \mathrm{C}$ em meio PW modificado líquido (Figuras 6 -10), poucas semelhanças foram observadas. O número de proteínas extracelulares produzidas em meio PW modificado líquido foi maior do que no meio BCYE. Isto pode ter ocorrido devido às diferenças no processo de extração de proteínas extracelulares, aos meios de cultivo utilizados para o crescimento da bactéria e aos períodos de extração das proteínas.

Nos ensaios realizados neste trabalho foi utilizado o meio PW modificado líquido para o cultivo de $X$. fastidiosa, e as proteínas secretadas no meio durante o crescimento da bactéria ao longo de 16 dias foram extraídas após a precipitação com uma solução de acetona:etanol, com posterior peletização e solubilização em tampão. No trabalho de Smolka et al. (2003) foi utilizado meio BCYE sólido para cultivo da bactéria e as proteínas foram extraídas após 21 dias de crescimento, através da lavagem das células com tampão de lise e inibidores de proteases.

Os meios de cultivo utilizados para o crescimento dos microrganismos influenciam o perfil protéico obtido (Cordwell et al., 2001). Tem sido relatado que muitas vias metabólicas expressas em meio mínimo não são expressas quando a bactéria cresce em meio complexo. Os trabalhos de Tao et al. (1999) 
e Khodursky et al. (2000) relatam que enzimas envolvidas na biossíntese de certos aminoácidos tendem a se acumular em menor quantidade quando a bactéria cresce em ambiente contendo aminoácidos disponíveis, comparado com meio pobre em aminoácidos.

Não foram identificadas proteínas extracelulares com alta massa molecular, através de 2D-PAGE, independente da temperatura de crescimento utilizada e do tempo de crescimento da bactéria (Figuras 6-10), muito embora essas proteínas tenham sido detectadas através de SDS-PAGE (dados não apresentados). Smolka et al. (2003) observaram a presença de várias proteínas de alta massa molecular através de 2D-PAGE, as quais não foram detectadas através de SDS-PAGE. Possivelmente essas proteínas não puderam ser resolvidas por 2D-PAGE devido à sua baixa abundância celular, ou não ressolubilizaram durante o preparo das amostras.

Um detalhe da área A do 2D-PAGE de proteínas extracelulares produzidas por $X$. fastidiosa durante 16 dias de incubação à $28^{\circ} \mathrm{C}$, pode ser visto na Figura 12. Neste detalhe pode ser observada a variação de 9 proteínas, denominadas de P1 - P9.

As proteínas $\mathrm{P} 2-\mathrm{P} 7$ tiveram acúmulo mínimo aos 4 dias de incubação à $28^{\circ} \mathrm{C}$. A proteína $\mathrm{P}_{1}$ foi detectada somente aos 4 dias de incubação. As proteínas $\mathrm{P} 2, \mathrm{P} 3, \mathrm{P} 7$ e P8 tiveram acúmulo máximo aos 16 dias enquanto que as proteínas $\mathrm{P} 4$, P5 e $\mathrm{P} 6$ tiveram acúmulo máximo aos 7 dias de incubação. As proteínas $\mathrm{P} 2$, P3 e P4 não foram detectadas aos 13 dias de incubação, sendo que a proteína $\mathrm{P} 2$ também não foi detectada aos 10 dias. As proteínas P8 e P9 não foram detectadas aos 4 e 10 dias de incubação da bactéria, sendo que a proteína P9 detectada somente aos 16 dias de incubação. 


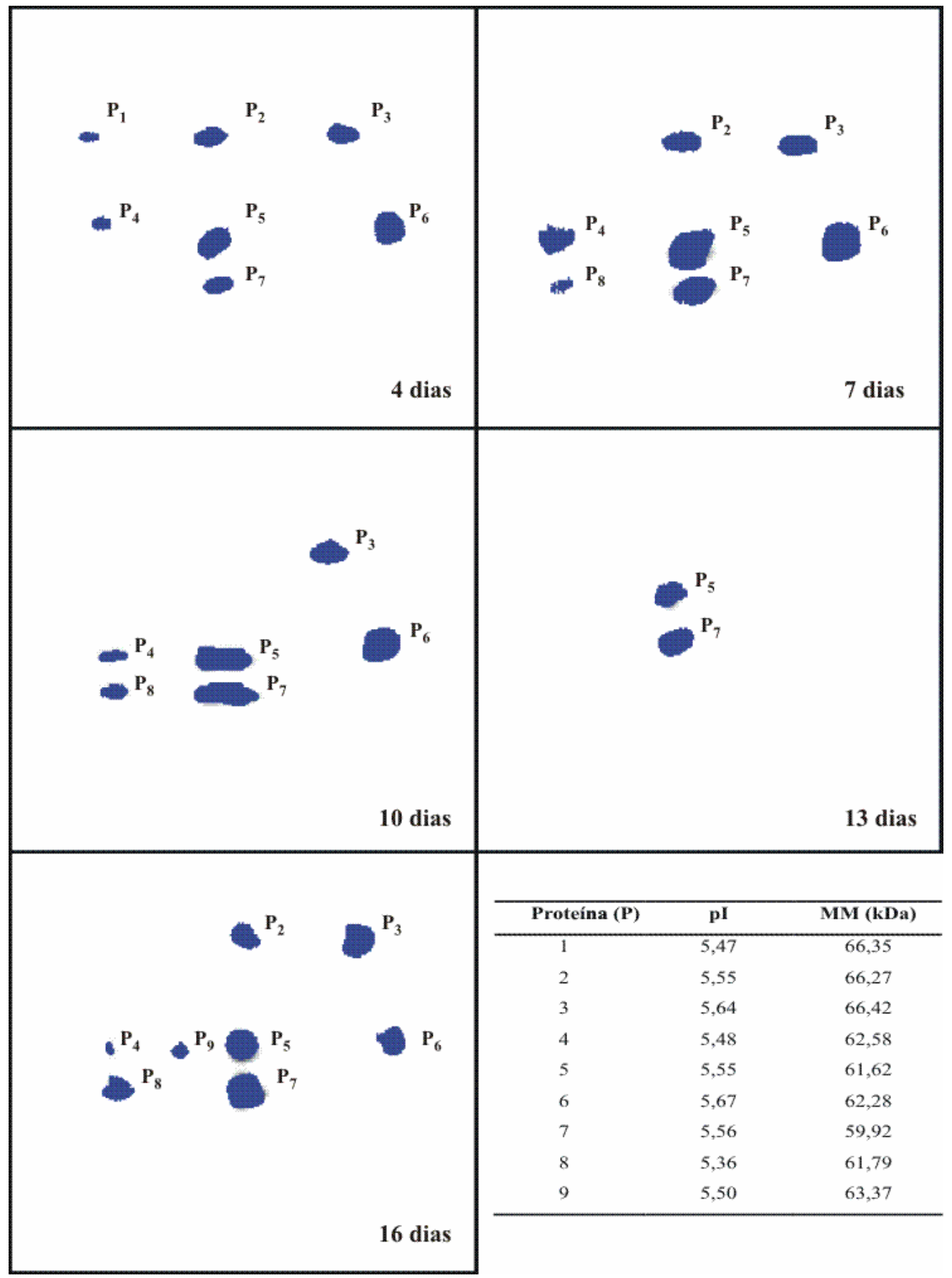

Figura 12 - Detalhe da área A do 2D-PAGE das proteínas extracelulares produzidas por $X$. fastidiosa em meio $\mathrm{PW}$ modificado líquido à $28^{\circ} \mathrm{C}$. pl: ponto isoelétrico aparente. MM: massa molecular. 
$\mathrm{Na}$ Figura 13 observa-se as proteínas extracelulares produzidas por $X$. fastidiosa durante 16 dias de incubação à $32^{\circ} \mathrm{C}$, correspondentes à área $\mathrm{A}$ dos géis. As proteínas correspondentes nessa área receberam a mesma denominação. As proteínas $\mathrm{P} 10$ e $\mathrm{P} 11$ foram detectadas somente à $32^{\circ} \mathrm{C}$. É possível que estas proteínas estejam sendo reguladas pela temperatura e induzidas em temperatura mais elevada $\left(32^{\circ} \mathrm{C}\right)$.

As proteínas $\mathrm{P} 2, \mathrm{P} 3, \mathrm{P} 5, \mathrm{P} 6, \mathrm{P} 7$ e P9 tiveram acúmulo mínimo aos 4 dias enquanto que as $\mathrm{P}_{1}$ e $\mathrm{P}_{4}$ e as proteínas $\mathrm{P} 8$ e P10 tiveram acúmulo mínimo aos 10 e 13 dias de incubação, respectivamente. As proteínas P1, P2, P7, P8, P9 e P10 tiveram acúmulo máximo aos 16 dias de incubação, enquanto que as proteínas $\mathrm{P} 3$, P5 e P6 e a proteína P4 tiveram acúmulo máximo aos 13 e 7 dias de incubação, respectivamente. As proteínas $\mathrm{P} 1, \mathrm{P} 4$ e $\mathrm{P} 8$ não foram detectadas aos 4 dias. As proteínas P8 e P10 não foram detectadas aos 10 dias de incubação. A proteína P11 somente foi detectada aos 16 dias de incubação.

$\mathrm{Na}$ Figura 14 observa-se as proteínas extracelulares produzidas por $X$. fastidiosa durante 16 dias de incubação à $28^{\circ} \mathrm{C}$, correspondentes à área $\mathrm{B}$ dos géis. As proteínas foram denominadas P12-P17. Nota-se novamente um acúmulo transiente dessas proteínas de acordo com o crescimento bacteriano. As proteínas $\mathrm{P} 12$ - P15 tiveram acúmulo máximo aos 7 dias e acúmulo mínimo aos 4 dias de incubação, com exceção da proteína P15 que teve acúmulo mínimo aos 13 dias. As proteínas P16 e P17 somente foram detectadas aos 10 dias de incubação. 


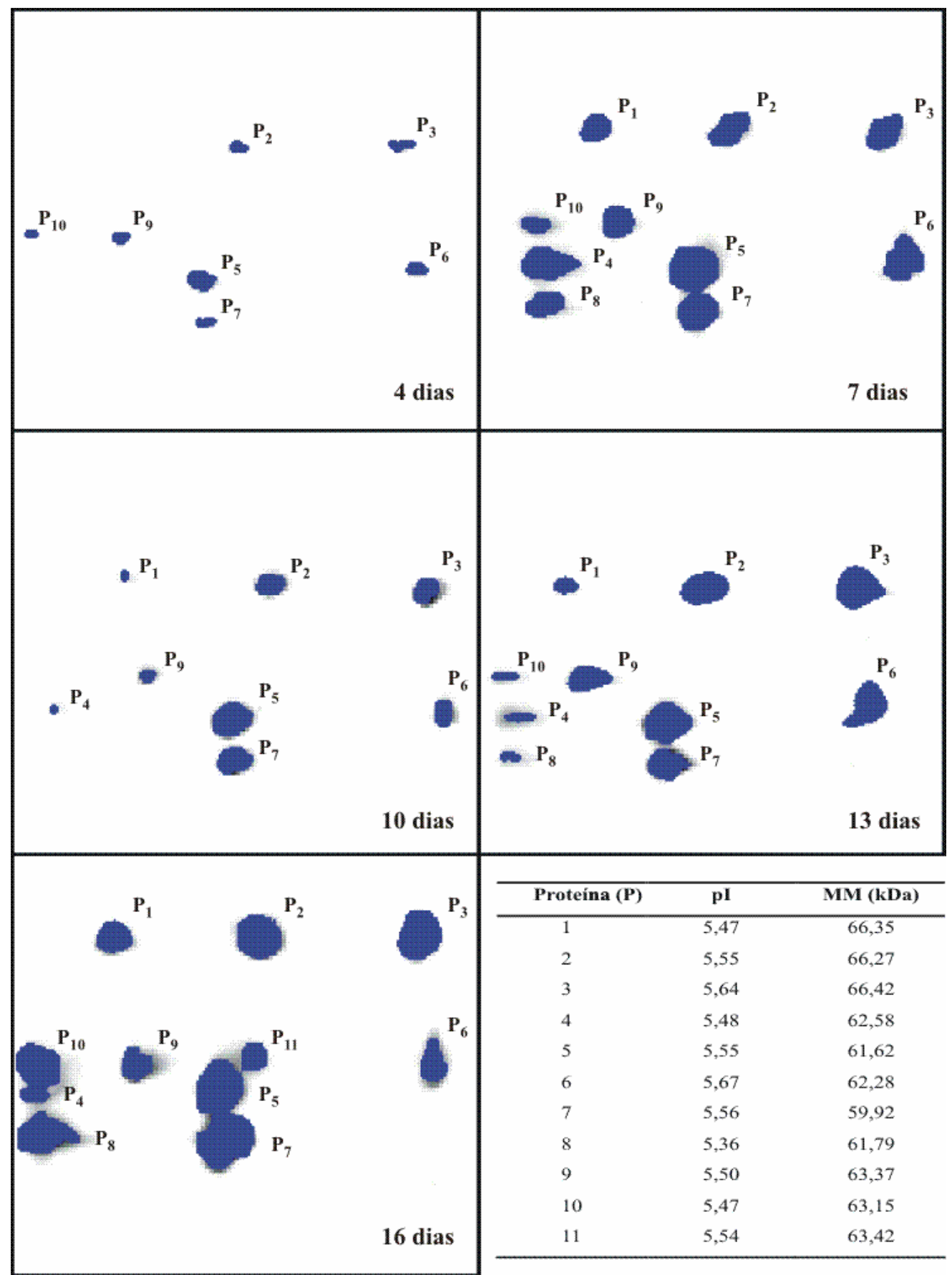

Figura 13 - Detalhe da área A do 2D-PAGE das proteínas extracelulares produzidas por $X$. fastidiosa em meio $\mathrm{PW}$ modificado líquido à $32^{\circ} \mathrm{C}$. pl: ponto isoelétrico aparente. MM: massa molecular. 


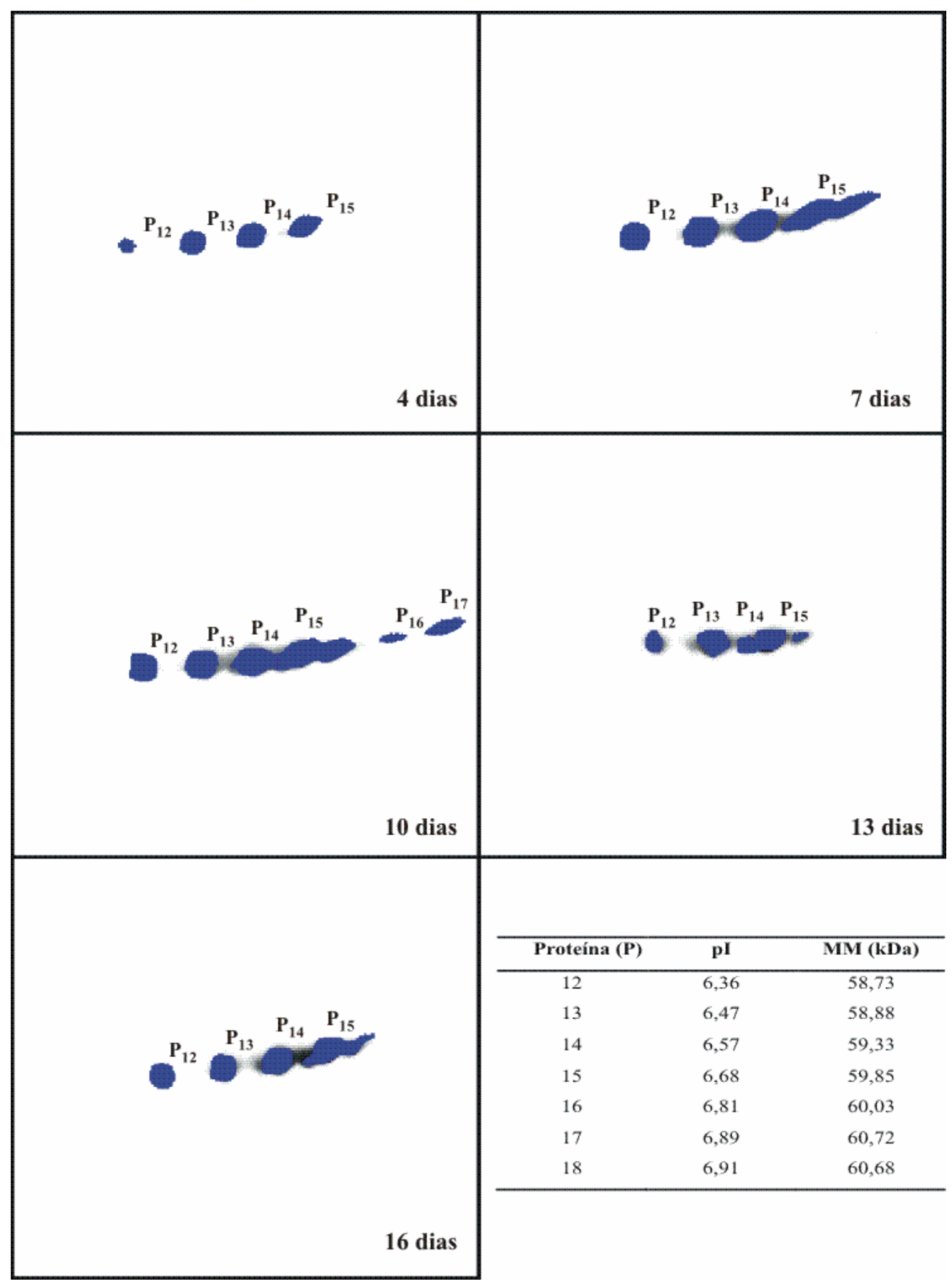

Figura 14 - Detalhe da área B do 2D-PAGE das proteínas extracelulares produzidas por $X$. fastidiosa em meio $\mathrm{PW}$ modificado líquido à $28^{\circ} \mathrm{C}$. pl: ponto isoelétrico aparente. MM: massa molecular. 
$\mathrm{Na}$ Figura 15 observa-se as proteínas extracelulares produzidas por $X$. fastidiosa durante 16 dias de incubação à $32^{\circ} \mathrm{C}$ e correspondem à área $\mathrm{B}$ dos géis. As proteínas foram denominadas de proteínas P12 - P18. A proteína P18 foi detectada somente à $32^{\circ} \mathrm{C}$. As proteínas $\mathrm{P} 12$ - P14 e P16 tiveram acúmulo mínimo aos 4 dias. As proteínas $\mathrm{P} 15$ e P17 tiveram acúmulo mínimo aos 7 dias de incubação. As proteínas P12, P13, P15 e P17 tiveram acúmulo máximo aos 16 dias de incubação. As proteínas P14 e P16 tiveram acúmulo máximo aos 13 dias de incubação. A proteína $\mathrm{P} 17$ não foi detectada aos 4 dias. A proteína P18 somente foi detectada aos 16 dias de incubação, sendo que à $28^{\circ} \mathrm{C}$ ela não foi detectada durante o crescimento da bactéria. É possível que a proteína P18 seja uma proteína induzida por temperaturas mais elevadas e durante a fase de declínio da cultura bacteriana.

$\mathrm{Na}$ Figura 16 observa-se as proteínas extracelulares produzidas por $X$. fastidiosa durante 16 dias de incubação à $28^{\circ} \mathrm{C}$ e que correspondem à área $\mathrm{C}$ dos géis. As proteínas foram denominadas P19-P28 e não foi feito a análise detalhada nessa área dos géis de proteínas secretadas à $32^{\circ} \mathrm{C}$.

As proteínas P19, P22, P23 e P26 tiveram acúmulo mínimo aos 4 dias de incubação. As proteínas P24 e P25 tiveram acúmulo mínimo aos 7 dias. A proteína P27 teve acúmulo mínimo aos 10 dias. As proteínas P20, P21, e P28 tiveram acúmulo mínimo aos 13 dias. As proteínas P24 e P25 e tiveram acúmulo mínimo aos 7 dias. A proteína P27 e a proteína P26 tiveram acúmulos máximo aos 4 dias e 7 dias, respectivamente. As proteínas P19, P21 e P22 e tiveram acúmulo máximos aos 10 dias. As proteínas $\mathrm{P} 20, \mathrm{P} 23, \mathrm{P} 24, \mathrm{P} 25$ e P28 tiveram acúmulo máximo aos 16 dias de incubação. A proteína P28 não foi detectada aos 4, 7 e 10 dias e as proteínas P19 e P22 não foram detectadas aos 13 dias de incubação. 


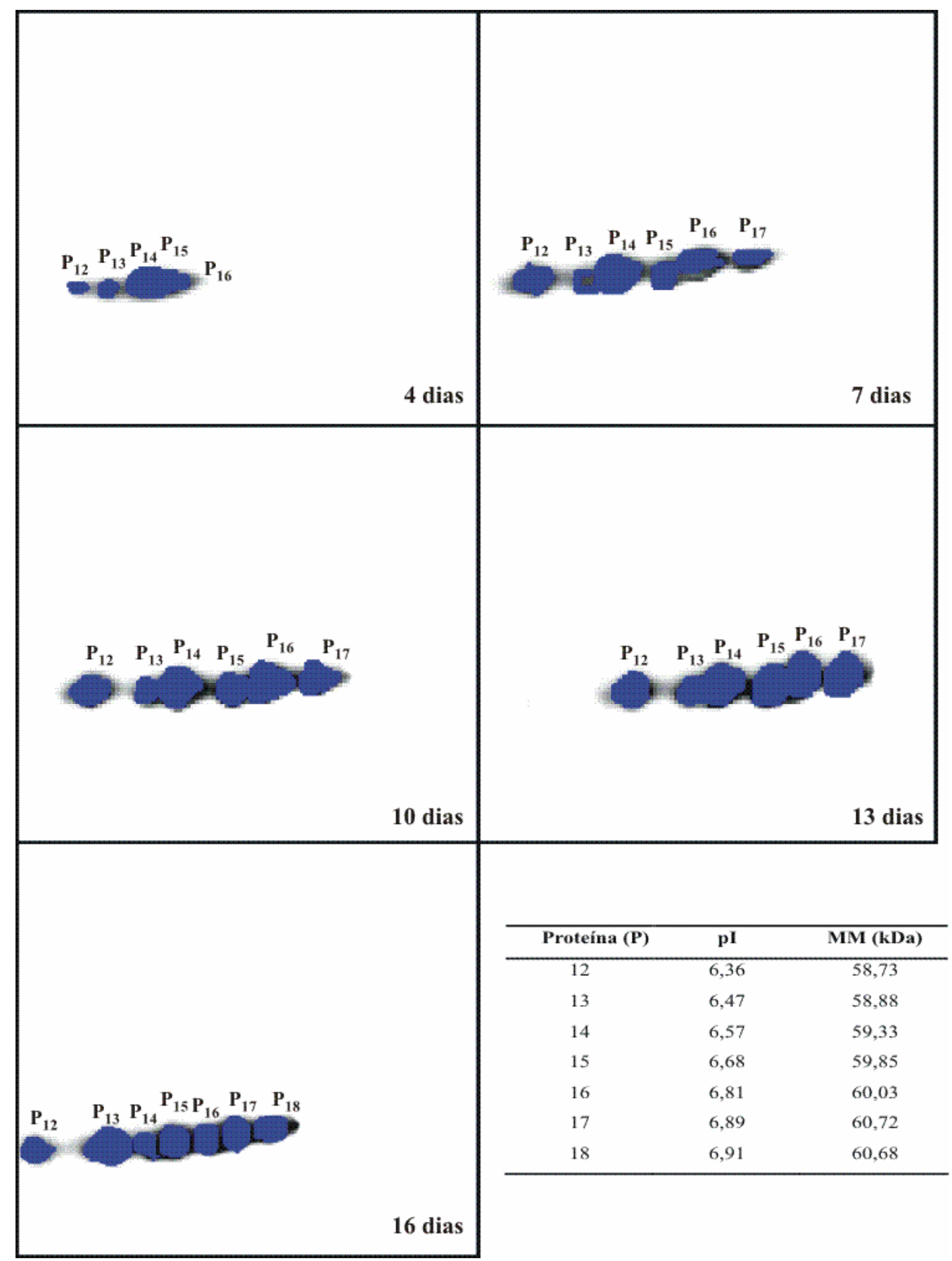

Figura 15 - Detalhe da área B do 2D-PAGE das proteínas extracelulares produzidas por $X$. fastidiosa em meio $\mathrm{PW}$ modificado líquido à $32^{\circ} \mathrm{C}$. pl: ponto isoelétrico aparente. MM: massa molecular. 


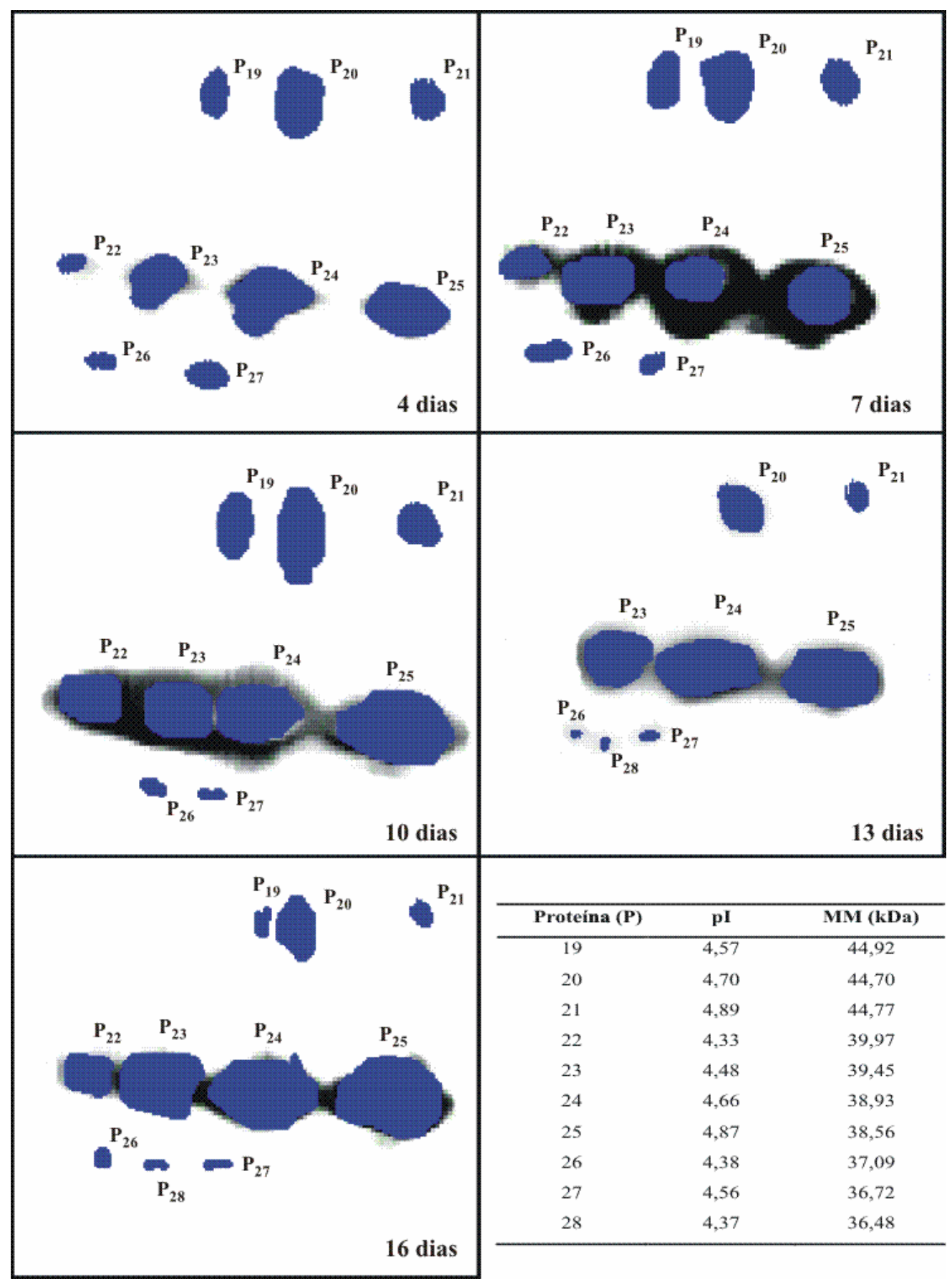

Figura 16 - Detalhe da área C do 2D-PAGE das proteínas extracelulares produzidas por $X$. fastidiosa em meio $\mathrm{PW}$ modificado líquido à $28^{\circ} \mathrm{C}$. pl: ponto isoelétrico aparente. MM: massa molecular. 
Na Figura 17 observa-se as proteínas extracelulares produzidas por $X$. fastidiosa após 16 dias de incubação à $32^{\circ} \mathrm{C}$ e que correspondem à área $\mathrm{D}$ dos géis. As proteínas foram denominadas de P29-P35. As proteínas P29P35 somente foram detectadas aos 4 dias de incubação à $32^{\circ} \mathrm{C}$, sendo suprimidas posteriormente. À $28^{\circ} \mathrm{C}$ essas proteínas não foram detectadas, independente da fase de crescimento da bactéria. É possível que as proteínas $\mathrm{P} 29$ - P35 sejam induzidas em condições de alta temperatura $\left(32^{\circ} \mathrm{C}\right)$, pois não foram detectadas à $28^{\circ} \mathrm{C}$, e que sejam induzidas somente no início da fase exponencial de crescimento de $X$. fastidiosa.

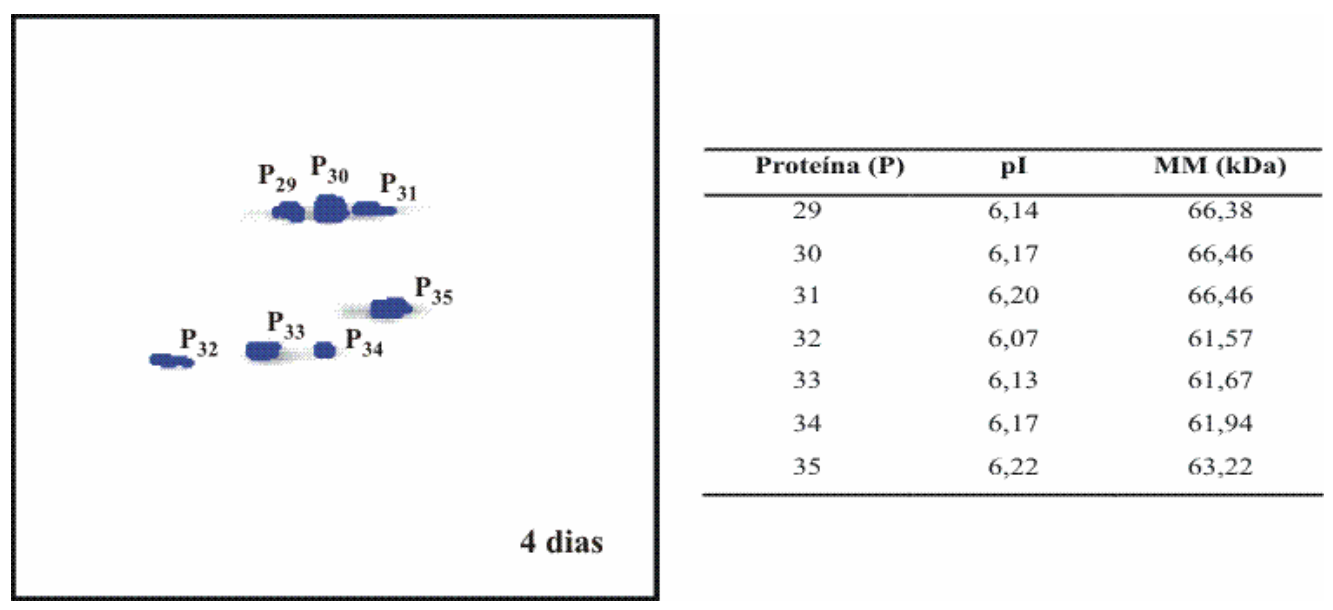

Figura 17 - Detalhe da área D do 2D-PAGE das proteínas extracelulares produzidas por $X$. fastidiosa em meio PW modificado líquido à $32^{\circ} \mathrm{C}$. pl: ponto isoelétrico aparente. MM: massa molecular.

Nas Figuras 18 e 19 pode-se observar o acúmulo diferencial de algumas proteínas extracelulares produzidas por $X$. fastidiosa à 28 e $32^{\circ} \mathrm{C}$ (áreas A, B, C e D), em função do tempo de crescimento em meio PW modificado líquido, através de uma escala de cores. Análises de agrupamentos hierárquicos também foram utilizadas (Figuras 20 e 21). 


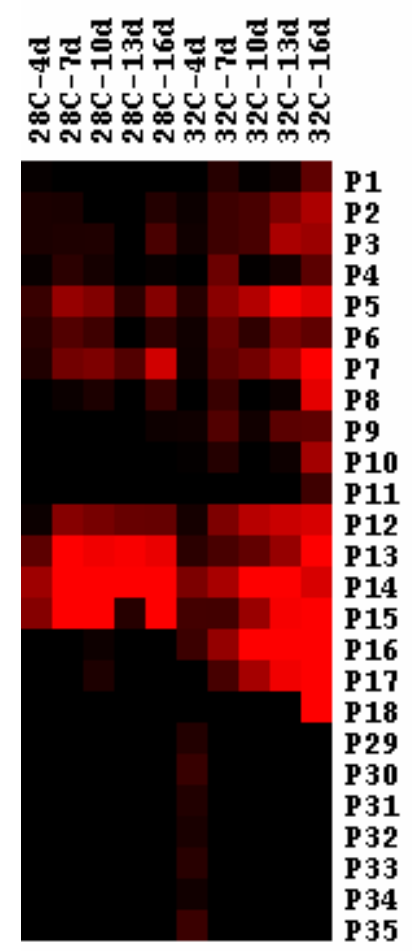

Figura 18 - Acúmulo diferencial das proteínas extracelulares produzidas por $X$. fastidiosa em meio PW modificado líquido à 28 e $32^{\circ} \mathrm{C}$. As proteínas foram detectadas nas áreas A, B e D dos géis.

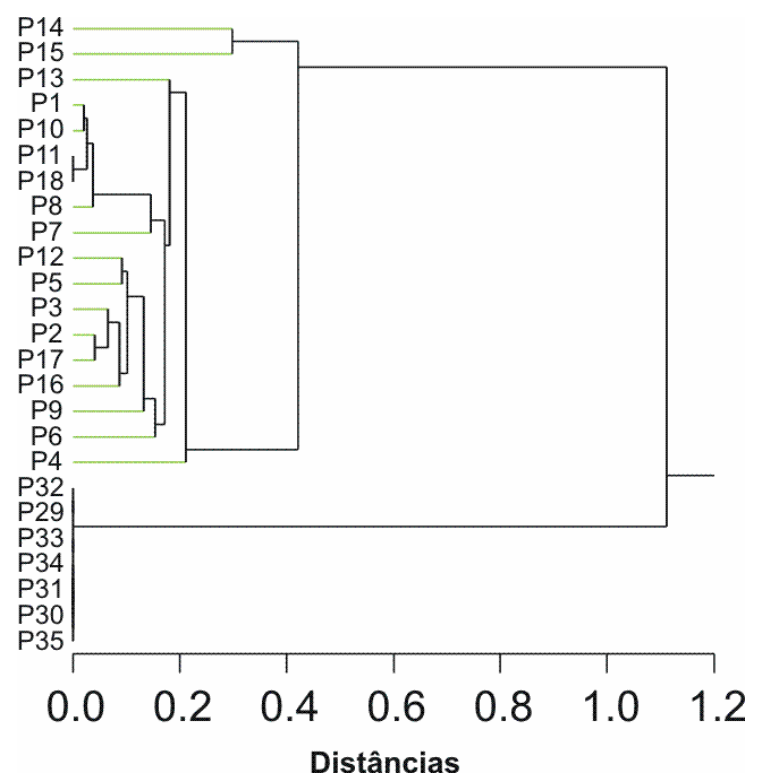

Figura 19 - Agrupamento hierárquico do proteoma extracelulares de $X$. fastidiosa em meio PW modificado líquido à 28 e $32^{\circ} \mathrm{C}$. As proteínas foram detectadas nas áreas A, B e D dos géis. 
De uma maneira geral, a análise dos dados da Figura 19, através de agrupamento hierárquico, permitiu a identificação de basicamente três grupos de proteínas com comportamentos similares: Grupo 1, P14 e P15; Grupo 2, P1 P13, P16 e P17; Grupo 3, P29 - P35.

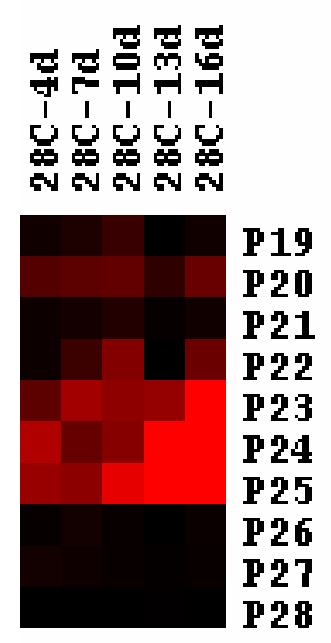

Figura 20 - Acúmulo diferencial das proteínas extracelulares produzidas por $X$. fastidiosa em meio $\mathrm{PW}$ modificado líquido à $28^{\circ} \mathrm{C}$. As proteínas foram detectadas na área $C$ dos géis 2D-PAGE.

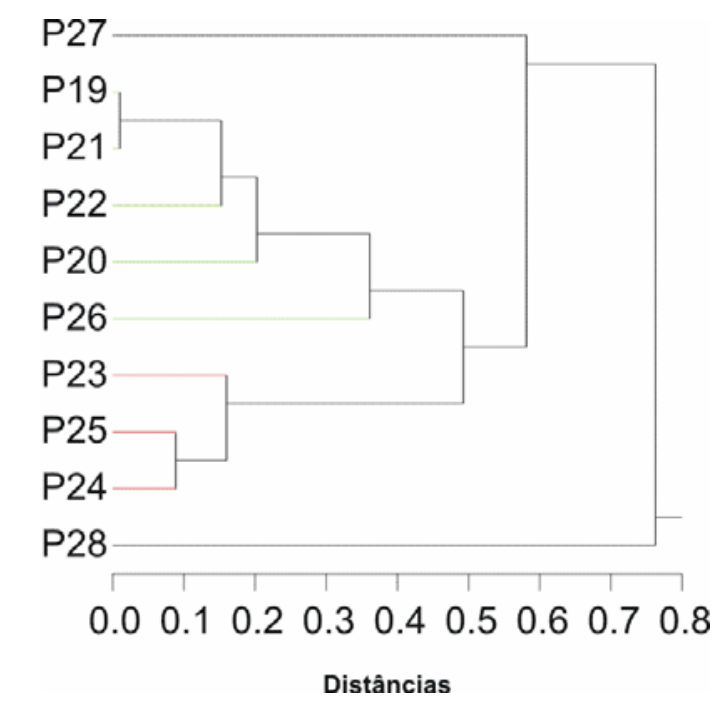

Figura 21 - Agrupamento hierárquico das proteínas extracelulares produzidas por $X$. fastidiosa em meio $\mathrm{PW}$ modificado líquido à $28^{\circ} \mathrm{C}$. As proteínas foram detectadas na área $C$ dos géis. 
A análise dos dados da Figura 21, através de agrupamento hierárquico, permitiu a discriminação de quatro grupos de proteínas com comportamento similares: Grupo 1, P27; Grupo 2, P28; Grupo 3, P23, P24 e P25; Grupo 4, P19, P20, P21, P22 e P26.

Proteínas com padrões de expressão bem definidos, como P29 à P35 seriam possíveis candidatos para a caracterização por espectrometria de massa.

O resumo das variações relativas do acúmulo de proteínas extracelulares de $X$. fastidiosa cultivada à 28 e $32^{\circ} \mathrm{C}$, podem ser visto nas Figuras 22,23 e 24.

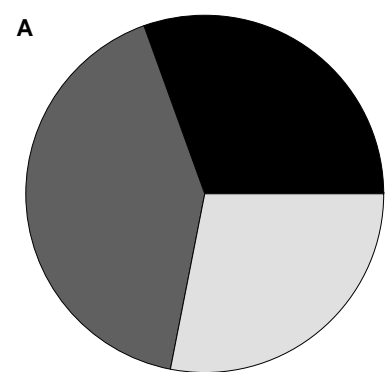

C

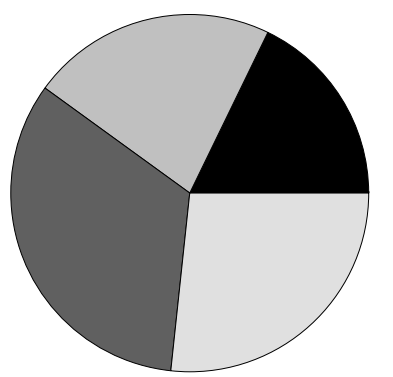

$$
\begin{aligned}
& \text { Sem variação } \\
& \text { Suprimidas } \\
& \square \text { Induzidas } \\
& \square \text { Únicas }
\end{aligned}
$$

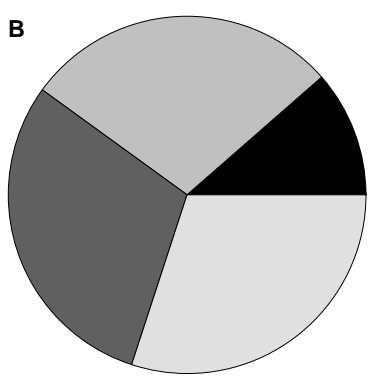

D

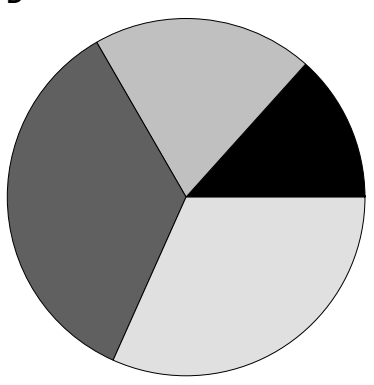

Figura 22 - Alterações no proteoma extracelular de $X$. fastidiosa cultivada em meio $\mathrm{PW}$ modificado líquido à $28^{\circ} \mathrm{C}$, em relação aos 4 dias de incubação. A: 7 dias; B: 10 dias C: 13 dias; D: 16 dias. 
A

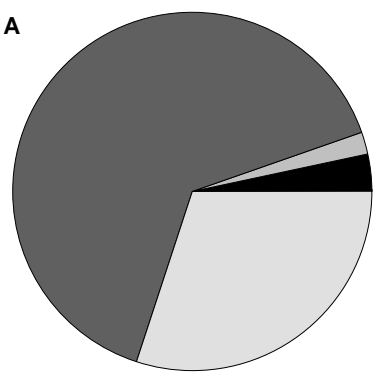

C

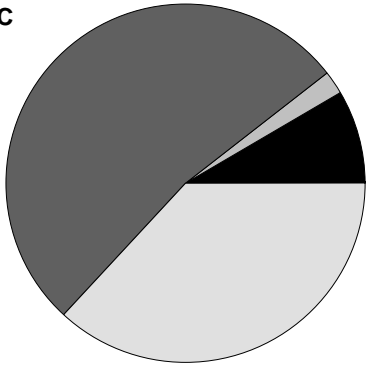

Sem variação $\square$ Suprimidas $\square$ Induzidas

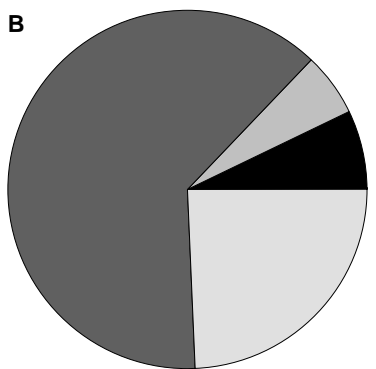

D

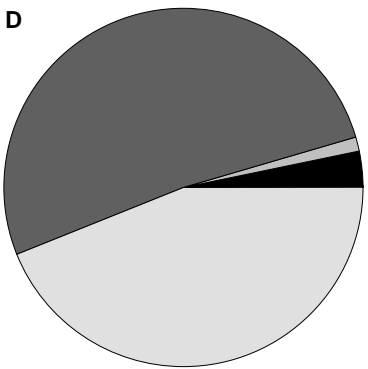

Figura 23 - Alterações no proteoma extracelular de $X$. fastidiosa cultivada em meio $\mathrm{PW}$ modificado líquido à $32^{\circ} \mathrm{C}$, em relação aos 4 dias de incubação. A: 7 dias; B: 10 dias C: 13 dias; D: 16 dias. 

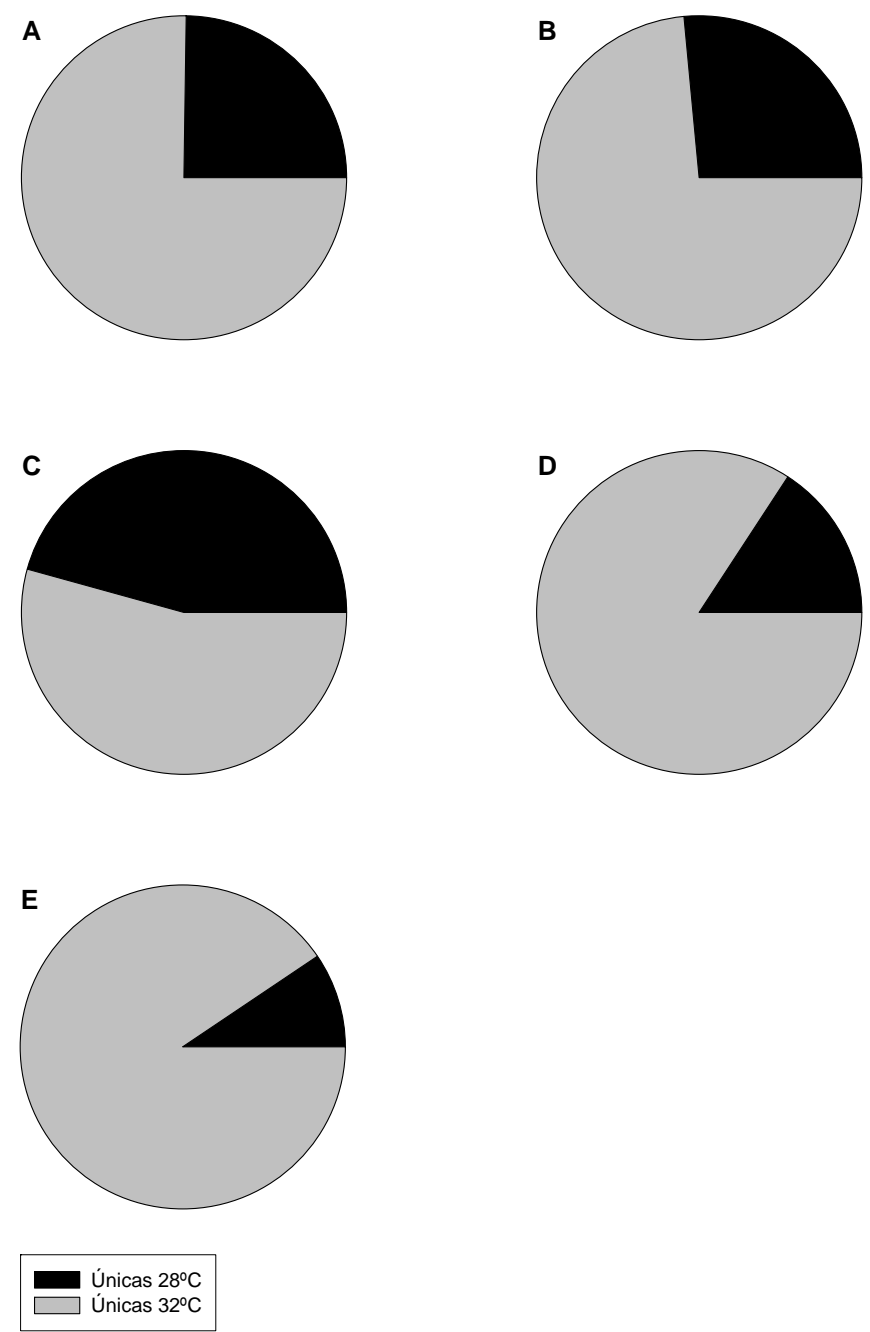

Figura 24 - Alterações no proteoma extracelular de $X$. fastidiosa cultivada em meio $\mathrm{PW}$ modificado líquido à $28^{\circ} \mathrm{C}$, em relação à $32^{\circ} \mathrm{C}$. $\mathrm{A}: 4$ dias; B: 7 dias C: 10 dias; D: 13 dias; E: 16 dias.

Durante o cultivo de $X$. fastidiosa, observa-se que há mais proteínas únicas sendo expressas à 32 do que à $28^{\circ} \mathrm{C}$. Após 13 dias, quando já na fase declínio, a quantidade de proteínas únicas expressas à 32 , em relação à $28^{\circ} \mathrm{C}$, é maior. É possível que essas proteínas únicas expressas nessas condições sejam proteínas envolvidas na manutenção de biofilmes e/ou fatores de patogenicidade/virulência putativos. 


\subsection{Bioensaios para detecção de moléculas sinais difusíveis}

\subsubsection{Bioensaio para detecção de lactonas de homoserina aciladas (LHAs)}

Por muitos anos LHAs foram exclusivamente associadas com a regulação da bioluminescência em alguns víbrios marinhos. No entanto, várias bactérias gram-negativas produtoras de LHAs e de inúmeros análogos tem sido identificadas, sugerindo que essas moléculas sejam sinalizadores de quorum comuns entre as bactérias gram-negativas.

Em muitas bactérias gram-negativas como A.tumefaciens, E. carotovora, $P$. aureofaciens e $R$. leguminosarum, entre outras, os mecanismos de percepção de quorum são análogos ao sistema LuxR/LuxI de $V$. fischeri. Entretanto, análises no genoma de $X$. fastidiosa já indicavam que não haviam seqüências similares aos membros da família Luxl, embora a bactéria tenha duas ORFs (XF2608 e XF0972) descritas como reguladores transcricionais da família LuxR.

Apesar de $X$. fastidiosa não possuir genes homólogos aos da família luxI, responsáveis pela síntese de LHAs, bioensaios para a detecção de LHAs foram realizados para determinar se $X$. fastidiosa sintetiza ou não essas moléculas.

Os resultados do bioensaio para detecção de LHAs podem ser observados na Figura 25. O controle positivo produziu um halo azul típico ao redor da colônia de $A$. tumefaciens $\mathrm{NT}_{1}$ (pTiC58 $\left.\Delta \mathrm{accR}\right)$. O controle negativo, A. tumefaciens $\mathrm{NTL}_{4}$ (pZLR4), não formou o halo (dados não apresentados). Da mesma forma, $X$. campestris pv. campestris, $X$. axonopodis pv. citri e a $X$. fastidiosa não produziram LHAs reconhecidas pelo sistema repórter.

Como o sistema de Agrobacterium é altamente sensitivo a maioria das LHAs (Shaw et al., 1997), os resultados indicam que $X$. fastidiosa 9a5c não sintetiza LHA, nas condições experimentais utilizadas. As estirpes de $X$. campestris pv. campestris e $X$. axonopodis pv. citri utilizadas também não 
sintetizam LHA reconhecidos pelo sistema repórter. Enquanto que A. tumefaciens $\mathrm{NT}_{1}$ (pTiC58 $\Delta \mathrm{accR}$ ), contendo o gene $\operatorname{tra}^{\mathrm{c}}$ no plasmídeo $\mathrm{Ti}$ e sintetizando constitutivamente LHA, demonstrou resultado positivo.

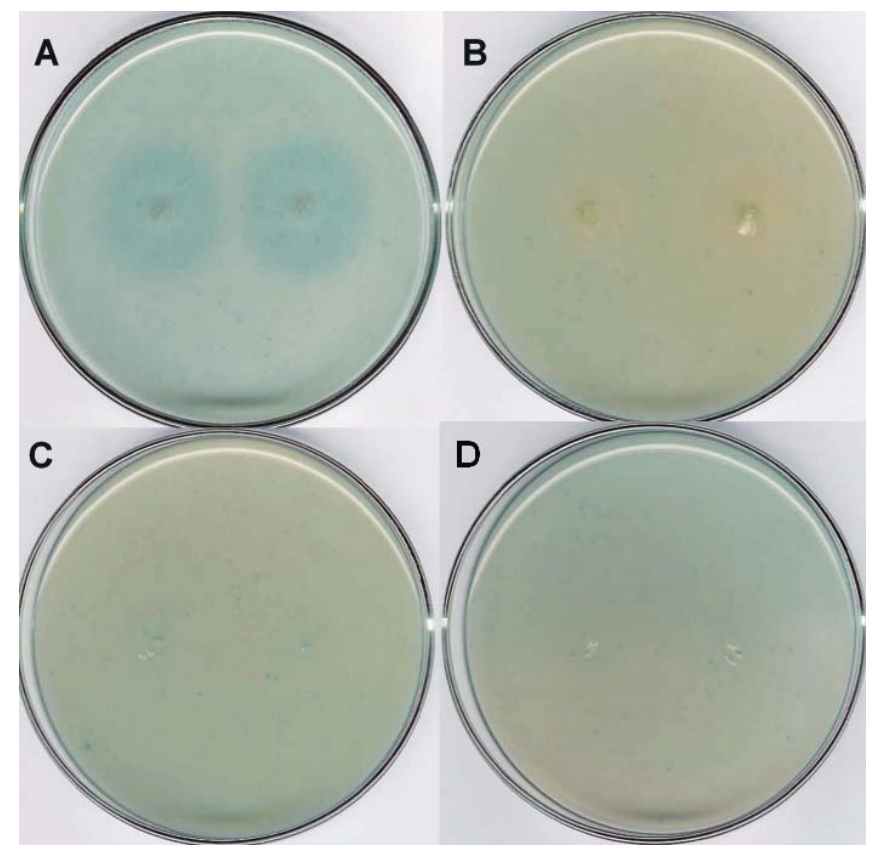

Figura 25 - Bioensaio para detecção de LHA. A: A. tumefaciens $\mathrm{NT}_{1}$ (pTiC58 $\triangle$ accR); B: X. campestris pv. campestris; C: $X$. axonopodis pv. citri; D: X. fastidiosa.

Os dados sugerem que existindo um sistema de percepção de quorum em X. fastidiosa, esse sistema não é mediado por LHAs.

\subsubsection{Bioensaio para detecção de DSF}

Foi demonstrado anteriormente que os genes de $X$. fastidiosa ortólogos aos genes rpfB e rpfF de $X$. campestris pv. campestris são expressos em meio PW modificado líquido, sugerindo que $X$. fastidiosa pode ter um sistema de sinalização envolvendo uma molécula sinal difusível similar ao DSF de $X$. campestris pv. campestris. 
Devido a alta homologia existente entre os genes $r p f$ de $X$. campestris pv. campestris e de $X$. fastidiosa, utilizou-se bioensaios com mutantes de $X$. campestris pv. campestris para detectar a produção de DSF por $X$. fastidiosa.

O bioensaio baseia-se na recuperação da atividade celulolítica por um mutante rpfF- de $X$. campestris pv. campestris, defectivo na síntese de DSF, pela adição de DSF ao meio (Barber et al., 1997).

Os resultados indicam que extratos de sobrenadantes acelulares de culturas de $X$. fastidiosa cultivadas durante 16 dias à $28^{\circ} \mathrm{C}$ em meio $\mathrm{PW}$ modificado líquido, possuem compostos capazes de restaurar a produção da endoglucanase pelo sistema repórter utilizado (Figura 26). O controle positivo, representado pelo extrato do sobrenadante acelular do mutante $r p f G H C$ de $X$. campestris pv. campestris, superprodutor de DSF, também formou um halo, como esperado (Figura 26).

$\mathrm{O}$ halo formado pelo mutante $r p f \mathrm{GHC}$ de $X$. campestris pv. campestris foi muito maior do que aquele formado por $X$. fastidiosa. $O$ controle negativo (extrato do sobrenadante acelular do mutante rpfF de $X$. campestris pv. campestris), o qual não produz o DSF, não formou halo, mostrando que 0 sistema repórter utilizado responde adequadamente ao DSF exógeno. 

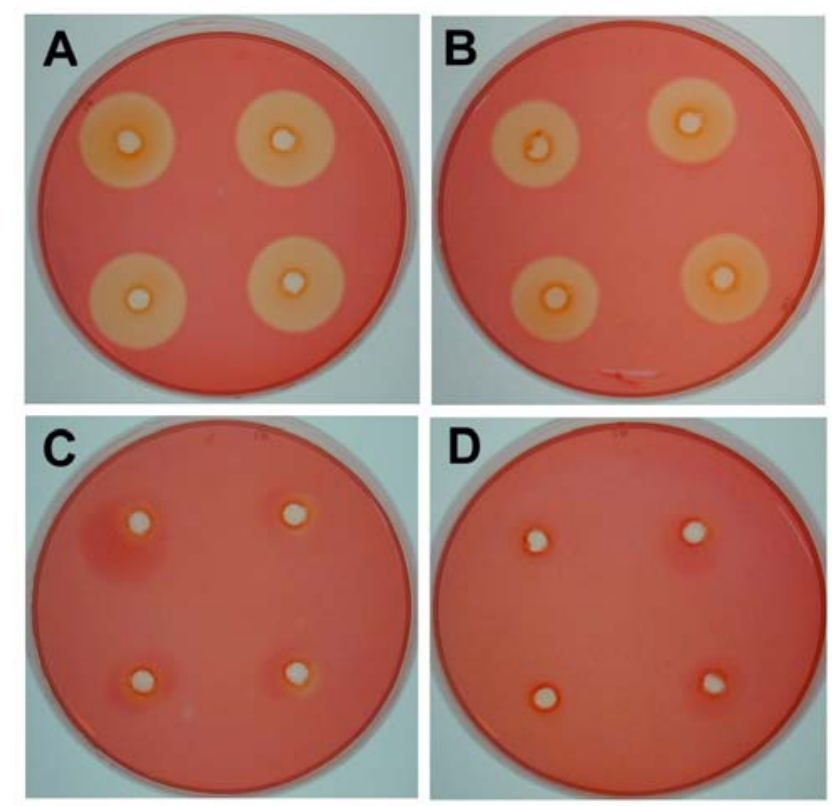

Figura 26 - Bioensaio para detecção de DSF. A e B: extratos de culturas do mutante rpfGHC de $X$. campestris pv. campestris. C: extratos de culturas de $X$. fastidiosa. D: extratos de culturas de mutantes rpfFde $X$. campestris pv. campestris (controle negativo).

Como não existem dados sobre a cinética de produção de DSF in vitro por $X$. fastidiosa, outro ensaio foi realizado para avaliar a produção de DSF pela bactéria durante seu crescimento por 20 dias no meio PW modificado líquido à $28^{\circ} \mathrm{C}$. A cinética de acúmulo de DSF sintetizado por $X$. fastidiosa em meio PW líquido sem albumina de soro bovino, pode ser vista na Figura 27. 


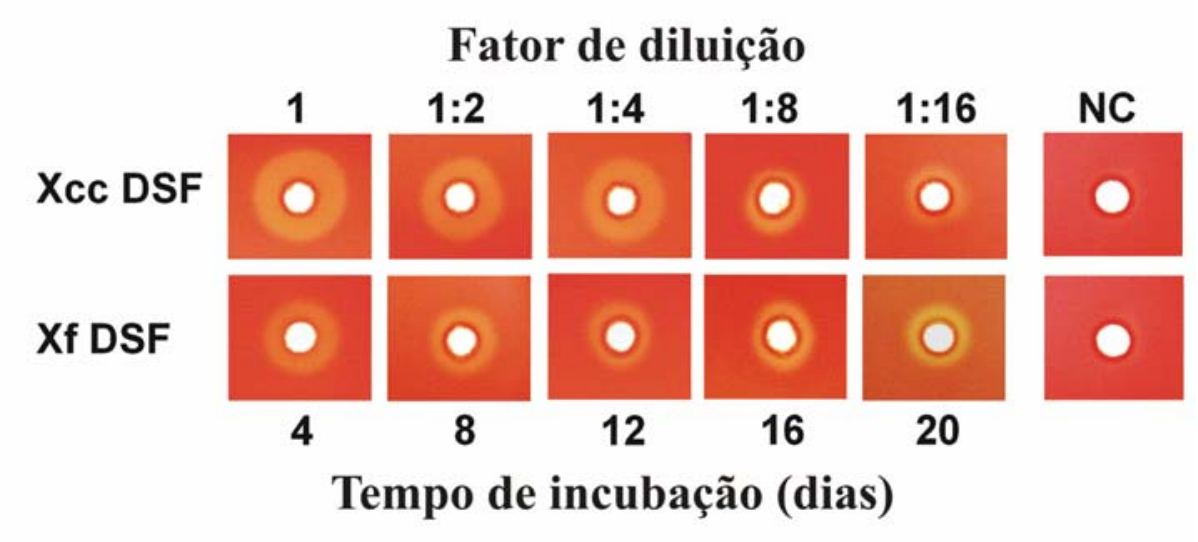

Figura 27 - Bioensaios de moléculas semelhantes à DSF feitos com diluições em série de extratos de culturas de mutantes rpfGHC de $X$. campestris pv. campestris (Xcc) ou extratos de culturas de $X$. fastidiosa (Xf) em diferentes tempos de incubação. NC: controle negativo (extratos dos meios caldo nutriente e PW modificado, respectivamente).

Os controles negativos $(\mathrm{CN})$ referentes ao extratos de sobrenadantes acelulares do mutante rpfF de $X$. campestris pv. campestris (pL6enggus) (Figura 26) e dos meios caldo nutriente e PW líquido modificado sem crescimento bacteriano (Figura 27), não foram capazes de restaurar a atividade de endoglucanase da bactéria repórter.

Analisando-se a produção de DSF pelo mutante rpfGHC de $X$. campestris pv. campestris, superprodutor de DSF, verificou-se que a concentração relativa do extrato demonstrou uma correlação direta (hipérbole retangular simples) com a área do halo de inibição formado $\left(r^{2}=0,9702\right)$ (Figura 28).

Podemos estimar que a capacidade do DSF produzido por $X$. fastidiosa (Figura 29), após 4 dias de incubação, para restaurar a produção de endoglucanase pela bactéria sensora, foi aproximadamente 14 vezes menor que a do DSF do extrato do mutante rpfGHC de $X$. campestris pv. campestris, 
sob nossas condições experimentais. A concentração de DSF de $X$. fastidiosa foi maior no início da fase exponencial de crescimento (4 dias) e, posteriormente (8 dias), decresceu aproximadamente $44 \%$.

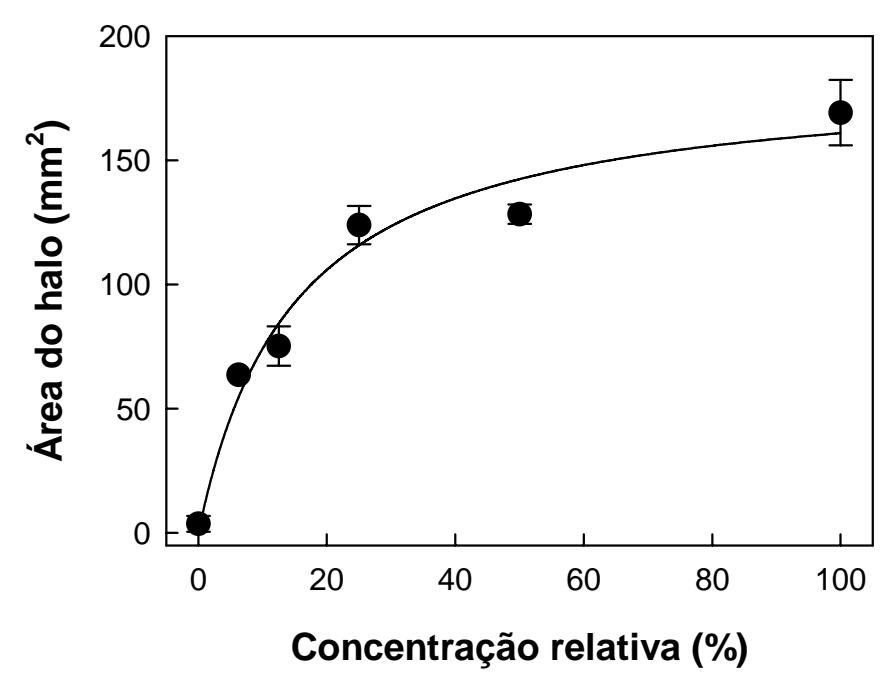

Figura 28 - Curva dose-resposta para extratos de culturas de mutantes rpfGHC de $X$. campestris pv. campestris. Os dados são médias de 3 repetições \pm erro padrão.

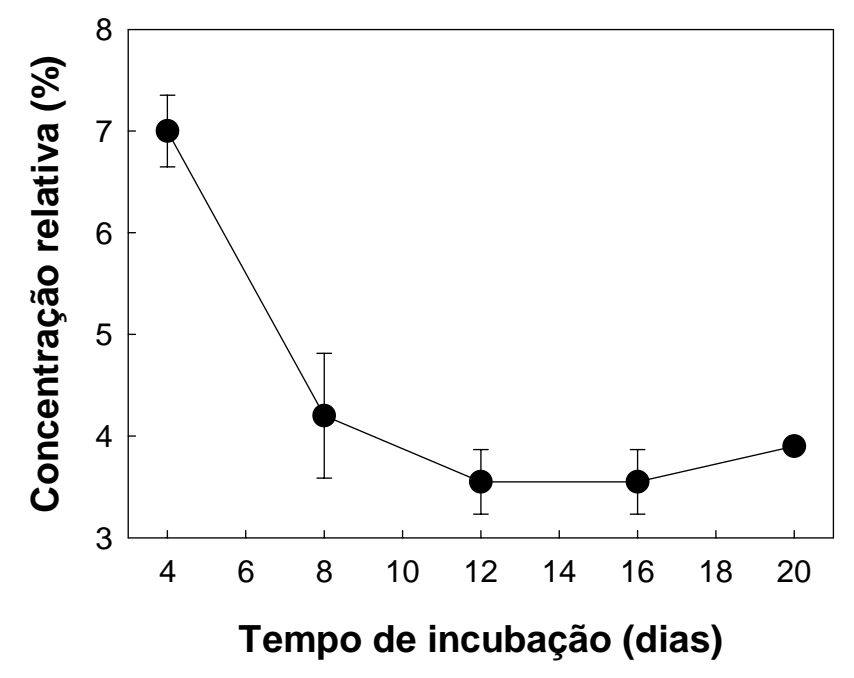

Figura 29 - Concentração relativa de moléculas semelhantes à DSFs sintetizadas por $X$. fastidiosa durante crescimento em meio PW modificado. Os dados são médias de 3 repetições \pm erro padrão. 
Os dados demonstram que $X$. fastidiosa 9a5c sintetizou uma molécula extracelular em meio líquido PW modificado, capaz de restaurar a atividade da endoglucanase do sistema repórter utilizado. Como a concentração desta molécula no meio de cultivo foi maior no início da fase exponencial de crescimento (4 dias) e decresceu posteriormente (10 dias), é possível que seu acúmulo neste meio seja dependente da densidade celular. Ao contrário, o acúmulo de DSF em cultivos de $X$. campestris pv. campestris, foi máximo no início da fase estacionária de crescimento e decresceu posteriormente (Barber et al., 1997).

O mecanismo que controla a persistência do DSF produzido por $X$. campestris pv. campestris ou por $X$. fastidiosa, em meio de cultura não está estabelecido. Barber et al. (1997) sugerem que o decréscimo na concentração de DSF de $X$. campestris pv. campestris no meio de cultivo pode ser resultado da degradação, modificação ou absorção pelas células. A caracterização química dos DSFs de $X$. campestris pv. campestris e da $X$. fastidiosa será essencial para determinar o nível de similaridade entre essas moléculas sinais, bem como os mecanismos que controlam suas vias de síntese e transdução.

Em $X$. campestris pv. campestris, a produção de enzimas e polissacarídeos extracelulares é um fator essencial para patogenicidade bacteriana e mutantes rpfF- apresentam virulência reduzida em plantas suscetíveis, mas induzem resposta de hipersensibilidade em plantas resistentes, caracterizando uma reação incompatível (Arlat et al., 1991). Estudos adicionais serão necessários para determinar se o DSF de $X$. fastidiosa está envolvido no sistema de percepção de quorum e na regulação dos genes de patogenicidade.

Trabalhos realizados por Hartung et al. (1994) e Almeida et al. (2001) mostraram que a presença de homogeneizados de tecidos de citros estimulam o crescimento in vitro de $X$. fastidiosa. Desta forma, é possível que moléculas semelhantes à DSFs, presentes no xilema de plantas infectadas com a bactéria, 
poderiam influenciar positivamente 0 crescimento bacteriano in planta, favorecendo a aglomeração em microcolônias e formação de biofilmes.

Observações feitas durante o crescimento da $X$. fastidiosa em meio de cultivo por Lemos et al. (2003) mostraram que o aumento do número de células bacterianas usadas como inóculo proporcionou um crescimento mais rápido e uma fase lag mais curta, sugerindo que o sistema de percepção de quorum pode regular o crescimento in vitro de $X$. fastidiosa.

\subsubsection{Caracterização parcial do DSF}

Barber et al. (1997) foram os primeiros a demonstrar que moléculas hidrofóbicas de baixa massa molecular podem ser extraídas de sobrenadantes de cultivos de Xanthomonas e que essas moléculas estimulam a produção de enzimas extracelulares em mutantes rpfF'.

Embora a estrutura da molécula de DSF ainda não tenha sido completamente elucidada, ela é um derivativo de ácidos graxos (Barber et al., 1997).

Extratos de sobrenadantes acelulares de cultivos de mutantes rpfGHC de $X$. campestris pv. campestris (superprodutor de DSF) e de $X$. fastidiosa foram fracionados por HPLC, utilizando-se uma coluna de fase reversa LC18 e gradiente de acetonitrila:água/TFA, durante 30 minutos e monitoradas à $210 \mathrm{~nm}$ (Figura 30). Observam-se perfis de eluição de moléculas bem semelhantes, onde os picos de maior área eluem entre 15 e 20 minutos. O extrato da X. fastidiosa apresentou três picos principais eluindo em 15,8; 16,3 e 17 minutos, enquanto o mutante $r p f G H C$, superprodutor de DSF, apresentou 2 picos eluindo em 15,8 e 16,3 minutos e um pico principal eluindo em 17 minutos.

Esses resultados sugerem que o sobrenadante das culturas de $X$. fastidiosa e de $X$. campestris pv. campestris (superprodutora de DSF), possuam moléculas com atividade de DSF semelhantes. Estudos adicionais 
deverão ser feitos para purificar e caracterizar quimicamente o DSF de $X$. fastidiosa. Adicionalmente, ensaios para determinação do efeito do DSF de $X$. fastidiosa sobre a expressão gênica global deverão ser realizados para caracterizar o papel dessa molécula na fisiologia da bactéria.

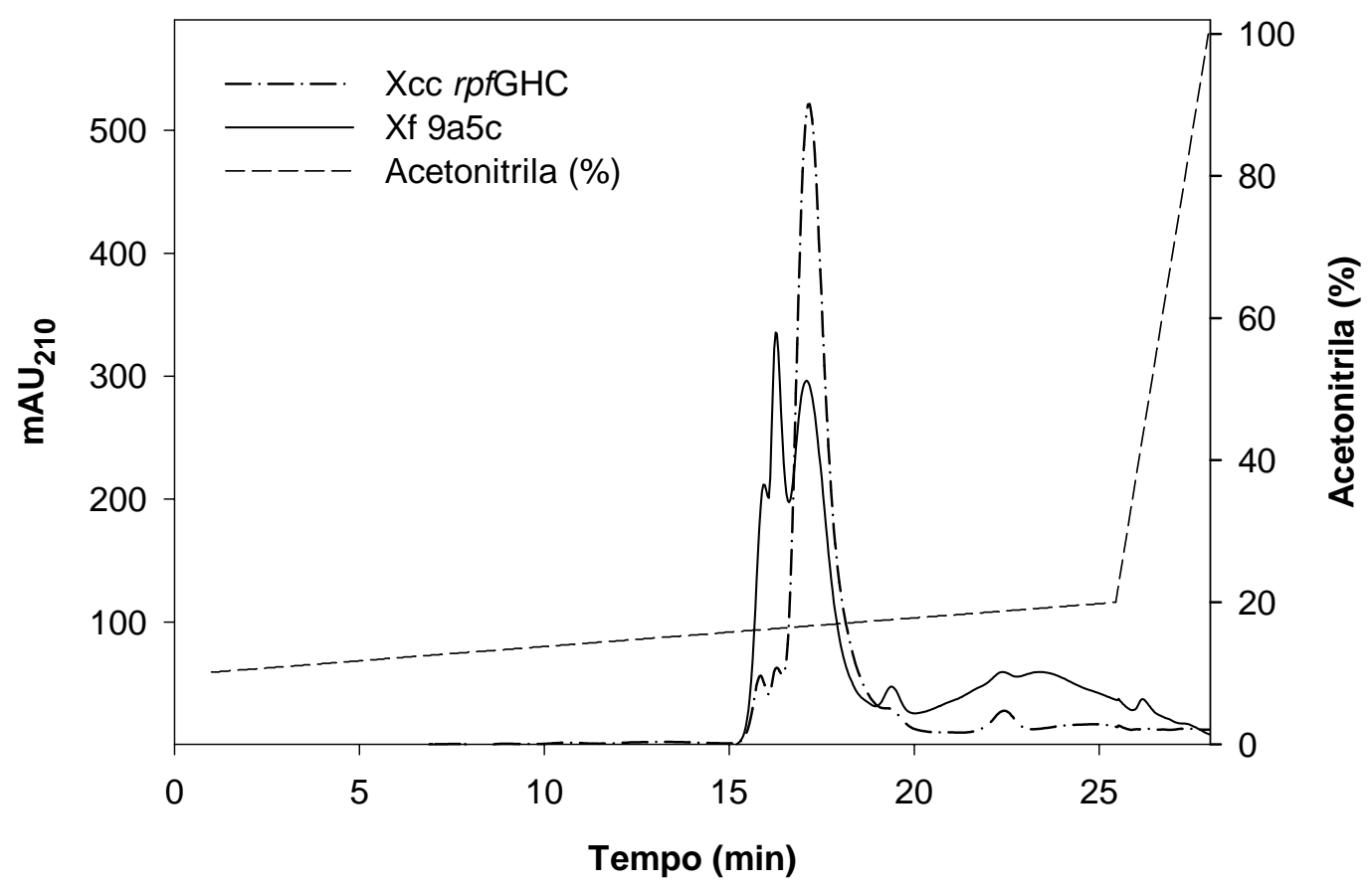

Figura 30 - Cromatograma de extratos de sobrenadantes acelulares de cultivos do mutantes rpfGHC de $X$. campestris pv. campestris $(\mathrm{Xcc})$ e de $X$. fastidiosa (Xf). Coluna Supelcosil LC18. Volume de injeção: $100 \mu \mathrm{L}$. Fluxo: $1 \mathrm{~mL} \mathrm{~min}^{-1}$. 


\section{CONCLUSÕES}

Com base nos resultados apresentados, podemos concluir que:

$\mathrm{O}$ crescimento de $X$. fastidiosa em meio $\mathrm{PW}$ modificado líquido à $28 \mathrm{e}$ $32^{\circ} \mathrm{C}$ não diferiram significativamente com base na $A_{600}$.

$\mathrm{O}$ crescimento de $X$. fastidiosa em meio PW modificado líquido, com base no número de UFC e viabilidade celular, é afetado pela temperatura (28 e $\left.32^{\circ}\right)$, tempos de incubação $(4,7,10,13$ e 16 dias) e pela interação entre esses fatores.

A expressão de proteínas extracelulares produzidas por $X$. fastidiosa em meio PW modificado líquido, é regulada pela temperatura e pelo tempo de incubação da bactéria. O número de proteínas secretadas à $32^{\circ} \mathrm{C}$ é maior do que à $28^{\circ} \mathrm{C}$.

A maior parte das proteínas extracelulares produzidas por X. fastidiosa são proteínas ácidas e de massa molecular aparente entre 20-60 $\mathrm{kDa}$.

Proteínas com acúmulo diferencial em função da temperatura e tempo de incubação, foram identificadas.

A $X$. fastidiosa sintetiza uma molécula extracelular no meio PW modificado líquido, semelhante ao DSF produzido por $X$.campestris pv. campestris, capaz de restaurar a atividade de endoglucanase através do sistema repórter utilizado. A concentração desta molécula extracelular produzida por $X$. fastidiosa é dependente da densidade bacteriana no meio. 
ANEXOS 
ANEXO A - Composição do meio de cultura PW modificado líquido para crescimento de $X$. fastidiosa.

\begin{tabular}{lc}
\hline Reagentes & Concentração $\left(\mathrm{g} \mathrm{L}^{-1}\right)$ \\
\hline $\mathrm{KH}_{2} \mathrm{PO}_{4}$ & $1,0 \mathrm{~g}$ \\
$\mathrm{~K}_{2} \mathrm{HPO}_{4}$ & $1,2 \mathrm{~g}$ \\
$\mathrm{MgSO}_{4} \cdot 7 \mathrm{H}_{2} \mathrm{O}$ & $0,4 \mathrm{~g}$ \\
Glutamina* & $4,0 \mathrm{~g}$ \\
Phytone peptone (BBL) & $4,0 \mathrm{~g}$ \\
Trypticase peptone (BBL) & $1,2 \mathrm{~g}$ \\
Hemin chloride & (Sigma) \\
Água destilada & $10,0 \mathrm{~mL}$ \\
\hline
\end{tabular}

*A glutamina em $100 \mathrm{~mL}$ de água destilada e esterilizar por filtração com membrana de acetato de celulose $(0,2 \mu \mathrm{m})$. Adicionar ao meio após a esterilização, em condições assépticas.

**Dissolver 0,01g em $100 \mathrm{~mL}$ de água destilada e adicionar ao meio.

Nota: para preparar o meio sólido acrescentar 1,5\% de ágar antes da esterilização. 
ANEXO B - Composição dos meios de cultura para crescimento de Xanthomonas spp. e Agrobacterium spp.

Meio Caldo Nutriente

\begin{tabular}{lc}
\hline Reagentes & Concentração $\left(\mathrm{g} \mathrm{L}^{-1}\right)$ \\
\hline Peptona & 5,0 \\
Extrato de carne & 3,0 \\
$\mathrm{NaCl}$ & 10,0 \\
Água destilada & $1000 \mathrm{~mL}$ \\
\hline Nota: para preparar o meio ágar nutriente acrescentar & $1,5 \%$ de ágar antes da \\
$\quad$ esterilização. & \\
& \\
& \\
Meio NYGA & \\
\hline Reagentes & Concentração $\left(\mathrm{g} \mathrm{L}^{-1}\right)$ \\
\hline Peptona & $5,0 \mathrm{~g}$ \\
Extrato de levedura & $3,0 \mathrm{~g}$ \\
Ágar & $15,0 \mathrm{~g}$ \\
Água destilada & $1000 \mathrm{~mL}$ \\
\hline
\end{tabular}

Meio NYGB

\begin{tabular}{lc}
\hline Reagentes & Concentração $\left(\mathrm{g} \mathrm{L}^{-1}\right)$ \\
\hline Peptona & $5,0 \mathrm{~g}$ \\
Extrato de levedura & $3,0 \mathrm{~g}$ \\
Água destilada & $1000 \mathrm{~mL}$ \\
\hline
\end{tabular}


ANEXO C-Componentes dos meios utilizados no ensaio para produção de lactonas de homoserina aciladas (LHAs).

Meio Mínimo AB

\begin{tabular}{lc}
\hline Reagentes & Concentração $\left(\mathrm{g} \mathrm{L}^{-1}\right)$ \\
\hline $\mathrm{KH}_{2} \mathrm{PO}_{4}$ & 3,0 \\
$\mathrm{NaH}_{2} \mathrm{PO}_{4}$ & 1,0 \\
$\mathrm{NH}_{4} \mathrm{Cl}$ & 1,0 \\
$\mathrm{MgSO}_{4} \cdot 7 \mathrm{H}_{2} \mathrm{O}$ & 0,3 \\
$\mathrm{KCl}$ & 0,15 \\
$\mathrm{CaCl}_{2} \cdot 2 \mathrm{H}_{2} \mathrm{O}$ & 0,01 \\
$\mathrm{Glicose}$ & 2,0 \\
FeSO & $7 \mathrm{H}_{2} \mathrm{O}$ \\
Água destilada & 0,0025 \\
\hline
\end{tabular}

Meio Soft Ágar

Reagentes Concentração $\left(\mathrm{g} \mathrm{L}^{-1}\right)$

Ágar 7,0

$\begin{array}{ll}\text { Água destilada } & 1000\end{array}$ 
ANEXO D - Composição dos meios de cultura utilizados nos bioensaios para detecção de DSF.

Meio MMX

\begin{tabular}{lc}
\hline Reagentes & Concentração $\left(\mathrm{g} \mathrm{L}^{-1}\right)$ \\
\hline $\mathrm{KH}_{2} \mathrm{PO}_{4}$ & 10,5 \\
$\mathrm{~K}_{2} \mathrm{HPO}_{4}$ & 4,5 \\
$\left(\mathrm{NH}_{4} \mathrm{PO}_{4}\right.$ & 1,0 \\
Citrato de sódio & 0,5 \\
Glicose & 0,5 \\
MgSO & 1,0 \\
Água destilada & $1000 \mathrm{~mL}$ \\
\hline
\end{tabular}

Meio MMXC

\begin{tabular}{lc}
\hline Reagentes & Concentração $\left(\mathrm{g} \mathrm{L}^{-1}\right)$ \\
\hline $\mathrm{KH}_{2} \mathrm{PO}_{4}$ & 10,5 \\
$\mathrm{~K}_{2} \mathrm{HPO}_{4}$ & 4,5 \\
$\left(\mathrm{NH}_{4} \mathrm{PO}_{4}\right.$ & 1,0 \\
Citrato de sódio & 0,5 \\
Glicose & 0,5 \\
MgSO$_{4}$ & 1,0 \\
Caseína hidrolisada & 1,5 \\
Água destilada & $1000 \mathrm{~mL}$ \\
\hline
\end{tabular}

Meio CMC-ágar

\begin{tabular}{lc}
\hline Reagentes & Concentração $\left(\mathrm{g} \mathrm{L}^{-1}\right)$ \\
\hline Carboximetilcelulose & 1,25 \\
Ágar & 10,0 \\
Tampão $\mathrm{K}_{2} \mathrm{HPO}_{4^{*}} \mathrm{pH} 6,0$ & $1000 \mathrm{~mL}$ \\
\hline
\end{tabular}




\section{REFERÊNCIAS BIBLIOGRÁFICAS}

ALMEIDA, R.P.P.; PEREIRA, E.F.; PURCELL, A.H. et al. Multiplication and movement of a citrus strain of Xylella fastidiosa within sweet orange. Plant Disease, v.85, n.4, p.382-286, 2001.

ARLAT, M.; GOUGH, C.L.; BARBER, C.E.; BOUCHER, C.; DANIELS, M.J. Xanthomonas campestris contains a cluster of $h r p$ related to the larger $h r p$ cluster of Pseudomonas solanacearum. Molecular Plant-Microbe Interactions, v.8, n.6, p.593-601, 1991.

ASSOCIAÇÃO BRASILEIRA DOS EXPORTADORES DE CITRUS (ABECITRUS). Clorose variegada dos citros. http://www.abecitros.com.br (26 jun. 1999)

AUSUBEL, F.M. BRENT, R.; KINGSTON, R.E. et al. Current protocols in Molecular Biology. New York: John Willey \& Sons, 1989. v.1. p.241-242.

BARBER, C.E.; TANG, J.L.; FENG, J.X. et al. A novel regulatory system required for pathogenicity of Xanthomonas campestris is mediated by a small diffusible signal molecule. Molecular Microbiology, v.24, n.3, p.555-566, 1997.

BARRAS, F.; VAN GIJSENGEM, C.; CHATTERJEE, A.K. Extracellular enzymes and pathogenesis of soft-rot Erwinia. Annual Review of Phytopathology, v.32, p.231-234, 1994.

BEDENDO, I.P. Ambiente e doença. In: BERGAMIN FILHO, A.; KIMATI, H.; AMORIM, L. (Ed.). Manual de Fitopatologia. 3.ed. São Paulo: Editora Agronômica Ceres, 1995. p.331-341.

BLUM, H.; BIER, H.; GROSS, H.J. Improved silver staining of plant proteins, RNA and DNA in polyacrilamide gels. Electrophoresis, v.8, n.2, p.93-95, 1987. 
BRELLES-MARIÑO, G.; BEDMAR, E.J. Detection, purification and characterization of quorum-sensing signals molecules in plant-associated bacteria. Journal of Biotechnology, v.91, n.2-3, p.197-209, 2001.

CAMPANHARO, J.C.; LEMOS, M.V.F.; LEMOS, E.G.M. Growth optimization procedures for the phytopathogen Xylella fastidiosa. Current Microbiology, v.46, n.1, p.99-102, 2003.

CARVALHO, M.L.V.; ROSSETI, V.; POMPEU JUNIOR, J. Evolução da sintomatologia de clorose variegada dos citros em laranja doce (C. sinensis). Fitopatologia Brasileira, v.20, p.351, 1995. (Suplemento)

CHA, C.; GAO, P.; CHEN, Y.C. et al. Production of acyl-homoserina lactone quorum-sensing signals by Gram-negative plant-associated bacteria. Molecular Plant Microbe Interactions, v.11, n.11, p.1119-1129, 1998.

CHEN, X.; SCHAUDER, S.; POTIER, N.; VAN DROSSELAER, A.; PELCZER, I. et al. Structural identification of a bacterial quorum-sensing signal containing boron. Nature, v.415, p.545-549, 2002.

CHUN, W.; CUI, J.; POPLAWSKY, A.R. Purification, characterization and biological role of a pheromone produced by Xanthomonas campestris pv. campestris. Physiological and Molecular Plant Pathology, v.51, n.1, p.114, 1997.

COLETTA-FILHO, H.D.; MACHADO, M.A. Evaluation genetic structural of Xylella fastidiosa populations from different Citrus sinensis varieties. Applied and Environmental Microbiology, v.68, n.8, p.3731-3736, 2002.

CORDWELL, S.J.; NOUVENS, A.S.; BRADLEY, J. Comparative proteomics of bacterial pathogens. Proteomics, v.1, n.2, p.461-472, 2001.

CUBO, M.T.; ECONOMOU, A.; MURPHY, G. et al. Molecular characterization and regulation of the rhizosphere-expressed genes rhiABCR that can influence nodulation of Rhizobium leguminosarum biovar viciae. Journal of Bacteriology, v.17, n.12, p.4026-4035, 1992.

D'ENFERT, C.; RYTER, A.; PUGSLEY, A.P. Cloning and expression in Escherichia coli of the Klebsiella pneumoniae genes for production, surfaces localization and secretion of the lipoprotein pullulanase. EMBO Journal, v.6, p.3531-3538, 1987.

DAVIES, M.J.; FRENCH, W.J.; SCHAAD, N.W. Axenic culture of the bacteria associated with phony disease of peach and plum leaf scald. Current Microbiology, v.6, n.1, p.309-314, 1981. 
DE NEGRI, J.D.; GARCIA JUNIOR, A. Sugestões para o manejo de pomares com clorose variegada de citros. Laranja, v.14, n.1, p.255-267, 1993.

DECKER, E.M. The ability of direct fluorescence-based, two-color assays to detect different physiological states of oral streptococci. Letters in Applied Microbiology, v.33, n.1, p.188-192, 2001.

DONADIO, L.C.; MOREIRA, C.S. Clorose variegada dos citros. 1.ed. Bebedouro: Fundecitrus, 1997. 162p.

DONG, Y.H.; WANG, L.H.; XU, J.L.; ZHANG, H.B.; ZHANG, X.F.; ZHANG, L.H. Quenching quorum sensing-dependent bacterial infection by an $\mathrm{N}$-acyl homoserina lactonase. Nature, v.411, p.813-817, 2001.

DOW, J.M.; DANIELS, M.J. Xylella genomics and bacterial pathogenicity. Yeast, v.17, n.1, p.263-271, 2000.

DOW, J.M.; DAVIES, H.A.; DANIELS, M.J. A metalloprotease from Xanthomonas campestris that specifically degrades proline/hydroxyprolinerich glycoproteins of the plant extracellular matrix. Molecular Plant Microbe Interactions, v.11, n.11, p.1085-1093, 1998.

DOW, J.M.; SCOFIELD, G.; TRAFFORD, K. et al. A gene cluster in Xanthomonas campestris pv. campestris required for pathogenicity controls the excretion of polygalacturonate lyase and other enzymes. Physiological and Molecular Plant Pathology, v.31, n.4, p.261-271, 1987.

DUMS, F.; DOW, J.M.; DANIELS, M.J. Structural characterization of protein secretion genes of the bacterial phytopathogen Xanthomonas campestris pathovar campestris to secretion systems of other Gram-negative bacteria. Molecular Gene Genetics, v.229, n.3, p.357-364, 1991.

EBERHARD, A. Inhibition and activation of bacterial luciferase synthesis. Journal of Bacteriology, v.109, n.3, p.1101-1105, 1972.

FEIL, H.; PURCELL, A.H. Temperature-dependent growth and survival of Xylella fastidiosa in vitro and in potted grapevines. Plant Disease, v.85, n.12, p.1230-1234, 2001.

FLAVIER, A.B.; GANOVA-RAEVA, L.M.; SCHELL, M.A.; DENNY, T.P. Hierarchical autoinduction in Ralstonia solanacearum: control of acylhomoserine lactone production by a novel autoregulatory system responsive to 3-hydroxypalmitic and methyl ester. Journal of Bacteriology, v.179, n.23, p.7089-7097, 1997. 
FRENCH, W.I.; STASSI, D.L. Response of phony-infected peach trees with gibberelic acid. HortScience, v.13, n.2, p.158-159, 1978.

FRY, S.M.; MILHOLLAND, R.D.; HUANG, P.Y. Isolation and growth and survival of Xylella fastidiosa from infected grapevines on nutrient agar media. Plant Disease, v.74, n.5-6, p.522-524, 1990.

FUNDO DE DEFESA DA CITRICULTURA (FUNDECITRUS). Clorose variegada dos citros (CVC). http://www.fundecitrus.com.br (03 ago. 2001)

FUNDO DE DEFESA DA CITRICULTURA. Manual de convivência com a CVC. Bebedouro: Centro de Pesquisas Cítricas, 1997. 15p.

FUQUA, C.; WINANS, S.C.; GREENBERG, E.P. Census and consensus in bacterial ecosystem: the luxR-Luxl family of quorum-sensing transcriptional regulators. Annual Review of Microbiology, v.50, p.727-751, 1996.

FUQUA, C.; WINANS, S.C.; GREENBERG, E.P. Quorum sensing in bacteria: the LuxR/Luxl family of cell density-responsive transcriptional regulators. Journal of Bacteriology, v.176, n.2, p.269-275, 1994.

GRAM, L.; CHRISTENSEN, A.B.; RAVN, L.; MOLIN, S.; GIVSKOV, M. Production of acylated homoserine lactones by psychrotrophic Enterobacteriaceae isolated from foods. Applied Environmental Microbiology, v.65, p.3458-3463, 1999.

GRAVENA, S. Cigarrinhas: mais uma preocupação para os citriculturores. Coopercitros: Informativo Agropecuário, v.11, n.124, p.8-14, 1997.

HARTUNG, J.S.; BERETTA, J.; BRLANSKY, R.H.; SPISSO, J.; LEE, R.F. Citrus variegated chlorosis bacterium: axenic culture, pathogenicity, and serological relationships with other strains of Xylella fastidiosa. Phytopathology, v.84, p.591-597, 1994.

HASSE, L. A laranja no Brasil. São Paulo: Editora Duprat \& lobe, 1987.54p.

HAYWARD, A.C.; MARIANO, R.L. Mecanismos de patogenicidade e virulência de procariotos em plantas. Revisão Anual de Patologia de Plantas, v.5, p.199-234, 1997.

HOLDEN, M.T.G.; CHHABRA, S.R.; DE NYS, R.; STEAD, P.; BAINTON, N.J. et al. Quorum-sensing cross talk: isolation and chemical characterization of cyclic dipeptides from Pseudomonas aeruginosa and other gram-negative bacteria. Molecular Microbiology, v.33, n.6, p.1254-1266, 1999. 
HOPKINS, D.L. Xylella fastidiosa: xylem-limited bacterial pathogen of plants. Annual Review of Phytopathology, v.27, p.271-290, 1989.

IHAKA, R.; GENTLEMAN, R.R. A language for data analysis and graphics. Journal of Computational and Graphical Statistics, v.5, n.3, p.299-314, 1996.

JONES, S.; YU, B.; BAINTON, N.J.; BIRDSALL, M. et al. The lux autoinducer regulates the production of exoenzyme virulence determinants in Erwinia carotovora and Pseudomonas aeruginosa. EMBO Journal, v.12, p.24772482, 1993.

KEEN, N.T.; DUMENYO, C.K.; YANG, C.H. et al. From rags to riches: insights from the first genomic sequence of a plant pathogenic bacterium. Genomic Biology, v.1, n.3, p.1019.1-1019.4, 2000.

KHODURSKY, A.B.; PETER, B.J.; COZZARELLI, N.R. et al. DNA microarray analysis of gene expression in response to physiological and genetic changes that affect tryptophan metabolism in Escheria coli. Proceedings of National Academic of Sciences USA, v.97, n.22, p.12170-12175, 2000.

KLEEREBEZEM, M.; QUADRI, L.E. Peptide pheromone-dependent regulation of antimicrobial peptide production in Gram-positive bacteria: a case of multicellular behavior. Peptides, v.22, n.10, p.1579-1596, 2001.

KOLTER, R.; SIEGELE, D.A.; TORMO, A. The stationary phase of the bacterial life cycle. Annual Review of Microbiology, v.47, p.855-874, 1993.

KOSTKA, S.J.; TATTER, T.A.; SHERALD, J.L.; HURTT, S.S. Mulberry leaf scorch, new disease caused by fastidious, xylem-limited bacterium. Plant Disease, v.70, n.5-6, p.690-693, 1986.

LALLY, E.T.; HILL, R.B.; KIEBA, I.R.; KOROSTOFF, S. The interaction between RTX toxins and target cells. Trends in Microbiology, v.9, n.2, p.356-361, 1999.

LAMBAIS, M.R.; GOLDMAN, M.H.S.; CAMARGO, L.E.A.; GOLDMAN, G.H. A genomic approach to the understanding of Xylella fastidiosa pathogenicity. Current Opinion in Microbiology, v.3, n.5, p.459-462, 2000.

LEE, B.; RAJU, B.C; NYLAND, G. et al. Phytotoxin(s) produced in culture by the Pierce's disease bacterium. Phytopathology, v.72, n.7, p.886-888, 1982. 
LEE, H.M.; WANG, K.C.; LIU, Y.L. et al. Association of the cytoplasmic membrane protein $\mathrm{XpsN}$ with the outer membrane protein XpsD in the type II secretion apparatus of Xanthomonas campestris pv. campestris. Journal of Bacteriology, v.182, n.6, p.1549-1557, 2000.

LEITE, B.; ISHIDA, M.L.; ALVES, E.; CARRER, H.; PASCHOLATI, S.F.; KITAJIMA, E.W. Genomics and X-ray microanalysis indicates that $\mathrm{Ca}^{2+}$ and thiols mediated the aggregation and adhesion of $X$. fastidiosa. Brazilian Journal of Medical and Biological Research, v.35, n.6, p.645-650, 2002.

LEITE, B.; PASCHOLATI, S.F.; KITAJIMA, E.W. et al. Mecanismos de adesão de bactérias e fungos às plantas hospedeiras. Revisão Anual de Patologia de Plantas, v.9, p.1-41, 2001.

LEMOS, E.G.M.; ALVES, L.M.C.; CAMPANHARO, J.C. Genomics-based design of defined growth media for the plant pathogen Xylella fastidiosa. FEMS Microbiology Letters, v.219, n.1, p.39-45, 2003.

LINDEBERG, M.; COLLMER, A. Analysis of eight out genes in a cluster required for pectin enzyme secretion by Erwinia chrysantemi: sequence comparison with secretion genes from other gram-negative bacteria. Journal of Bacteriology, v.174, n.22, p.7385-7397, 1992.

LITHGOW, J.K.; WILKINSON, A.; HARDMAN, A.; RODELAS, B.; WISNIEWSKIDYÉ, F.; WILLIAMS, P. DOWNIE, J.A. The regulatory locus cinRI in Rhizobium leguminosarum controls a network of quorum-sensing loci. Molecular Microbiology, v.37, n.1, p.81-97, 2000.

LOH, J.; CARLSON, R.W.; YORK, W.S.; STACEY, G. Bradyoxetin, a unique chemical signal involved in symbiotic gene regulation. Proceedings of National Academic of Sciences USA, v.99, n.22, p.14446-14451, 2002.

LORY, S. Secretion of proteins and assembly of bacterial surface organelles: shared pathway of extracellular protein targeting. Current Opinion in Microbiology, v.1, n.1, p.27-35, 1998.

MAcDOUGLAD, D.; RICE, S.A.; WEICHART, D; KJELLEBERG, S. Nonculturability: adaptation or debilitation? FEMS Microbiology Ecology, v.25, n.1, p.1-9, 1998.

MCCLEAN, K.H.; WINSON, M.K.; FISH, L. et al. Quorum sensing a Chromobacterium violaceum: explanation of violacein production and inhibition for the detection of $\mathrm{N}$-acyl homoserine lactones. Microbiology, v.143, n.12, p.3707-3711, 1997. 
MEIDANIS, J.; BRAGA, M.D.V.; VERJOVISKI-ALMEIDA, S. Whole genome analysis of transporters in the plant pathogen Xylella fastidiosa. Microbiology and Molecular Biology Reviews, v.60, n.2, p.272-299, 2002.

NOVIECK, R.P.; MUIR, T.W. Virulence gene regulation by peptides in staphylococci and other Gram-positive bacteria. Current Opinion in Microbiology, v.2, n.3, p.40-45, 1999.

OLIVER, J.D. The viable but non-culturable state in the human pathogen, Vibrio vulnificus. FEMS Microbiology Letters, v.133, n.3, p.203-208, 1995.

PARADELA FILHO, O.; SUGIMORI, M.H.; RIBEIRO, I.J.A. et al. Primeira constatação em cafeeiro no Brasil da Xylella fastidiosa causadora da clorose variegada dos citros. Laranja, v.16, n.2, p.135-136, 1995.

PASCHOLATI, S.F. Fisiologia do parasitismo In: BERGAMIN FILHO, A.; KIMATI, H.; AMORIM, L. (Ed.). Manual de Fitopatologia. 3.ed. São Paulo: Editora Agronômica Ceres, 1995. p.343-364.

PEARSON, J.P.; GRAY, B.H.; GREENBERG, E.P. The structure of the autoinducer molecule required for expression of Pseudomonas aeruginosa virulence genes. Proceedings of National Academic of Sciences USA, v.91, n.1, p.179-201, 1994.

PIRHONEN, M.D.; FLEGO, D.; HEIKINHEIMO, R.; PALVA, E.T. A small diffusible signal molecule is responsible for the global control of virulence and exoenzyme production in the plant pathogen Erwinia carotovora. EMBO Journal, v.12, p.2467-2476, 1993.

POOLER, M.R.; HARTUNG, J.S. Specific PCR detection and identification of Xylella fastidiosa strain causing citrus variegated chlorosis. Current Microbiology, v.31, n.6, p.377-381, 1995.

PURCELL, A.H.; HOPKINS, D.L. Fastidious xylem-limited bacterial plant pathogens. Annual Review of Phytopathology, v.34, p.131-151, 1996.

RAY, S.K.; RAJESHWARI, R.; SONTI, R.V. Mutants of Xanthomonas oryzae pv. oryzae deficient in general secretory pathway are virulence deficient and unable to secrete xylanase. Molecular Plant Microbe Interactions, v.13, n.4, p.394-401, 2000.

RUBY, E.G. Leassons from a cooperative bacterial-animal association: the Vibrio fischeri-Euprymna scolopes light organ. Annual Review of Microbiology, v.50, p.591-624, 1996. 
SALMOND, G.P.C. Secretion of extracellular virulence factors by plant pathogenic bacteria. Annual Review of Phytopathology, v.32, p.181-200, 1994.

SANDKVIST, M. Type II secretion and pathogenesis. Infection and Immunity, v.69, n.6, p-3523-3535, 2001.

SCARPARI, L.M. Modulação da expressão de genes de patogenicidade putativos em Xylella fastidiosa sob condições de baixa e alta densidade celular. Piracicaba, 2001. 85p. Dissertação (Mestrado) - Escola Superior de Agricultura "Luiz de Queiroz", Universidade de São Paulo.

SHAW, P.D.; PING, G.; DALY, S. et al. Detecting and characterizing acylhomoserine lactone signal molecules by thin layer chromatography. Proceedings of National Academic of Sciences USA, v.94, n.12, p.60366041, 1997.

SILVA, A.C.R.; FERRO, J.A.; REINACH, F.C. et al. Comparison of the genomes of two Xanthomonas pathogens with differing host specificities. Nature, v.417, p.459-463, 2002.

SILVA, D.S.; RODRIGUES, A.M.P. Detecção de fímbrias produzidas por Xylella fastidiosa no sistema vascular de folhas de citrus, através de microscopia eletrônica de varredura. Fitopatologia Brasileira, v.25, p.330, 2000. (Suplemento)

SIMPSON, A.J.G.; REINACH, F.C.; ARRUDA, P. et al. The genome sequence of the plant pathogen Xylella fastidiosa. Nature, v.406, n.6792, p.151-157, 2000.

SLATER, H.; ALVAREZ-MORALES, A.; BARBER, C.E. et al. A two-component system involving an HD-GYP domain protein links cell-cell signalling to pathogenicity gene expression in Xanthomonas campestris. Molecular Biology, v.38, n.5, p.986-1003, 2000.

SMOLKA, M.B.; MARTINS, D.; WINCK, F.V.; SANTORO, C.E.; CASTELLARI, R.R.; FERRARI, F. et al. Proteome analysis of the plant pathogen Xylella fastidiosa reveals major cellular and extracellular proteins and a peculiar codon bias distribution. Proteomics, v.3, n.1, p.224-237, 2003.

SWIFT, S.; WINSON, M.K.; CHAN, P.F. et al. A novel strategy for the isolation of luxl homologues: evidence for the widespread distribution of a LuxR:Luxl superfamily in enteric bacteria. Molecular Microbiology, v.10, n.2, p.511520, 1993. 
TANG, J.L.; FENG, J.X.; LI, Q.Q. et al. Cloning and characterization on the rpfC gene of Xanthomonas oryzae pv. oryzae: involvement in exopolysaccharide production and virulence to rice. Molecular Plant Microbe Interactions, v.9, n.7, p.664-666, 1996.

TANG, J.L.; LIU, Y.N.; BARBER, C.E. et al. Genetic and molecular analysis of a cluster of $r p f$ genes involved in positive regulation of synthesis of extracellular enzymes and polysaccharide in Xanthomonas campestris pv campestris. Molecular General Genetics, v.226, n.3, p.409-417, 1991.

TAO, H.; BAUSH, C.; RICHMOND, C.; BLATTNER, F.R.; CONWAY, T. Functional genomics: expression analysis of Escherichia coli growing on minimal and rich media. Journal of Bacteriology, v.181, n.20, p.64256440,1999 .

TARDY, F.; NASSER, W.; BAUDOUY, J.R.; PATTAT, N.H.C. Comparative analysis of the five major Erwinia chrysanthemi pectate lyases: enzyme characteristic and potential inhibitors. Journal of Microbiology, v.179, n.8, p.2503-2511, 1997.

VAN DIJK, K.; FOUTS, D.E.; REHM, A.H. et al. The Avr (effector) proteins HrmA (HopPsyA) and AvrPto are secreted in culture from Pseudomonas syringae pathovars via the Hrp (type III) protein secretion system in a temperature- and ph-sensitive manner. Journal of Bacteriology, v.181, n.16, p.4790-4797, 1999.

VAN SLUYS, M.A.; MONTEIRO-VITORELLO, C.B.; CAMARGO, L.E.A. et al. Comparative genomic analysis plant-associated bacteria. Annual Review of Phytopathology, v.40, p.169-189, 2002.

WAI, S.W.; MIZUNOE, Y.; YOSHIDA, S.-I. How Vibrio cholerae survival during starvation. FEMS Microbiology Letters, v.180, n.2, p.123-131, 1999.

WEICHART, D.; OLIVER, J.D.; KIJELLEBERG, S. Low temperature induced non-culturability and killing of Vibrio vulnificus. FEMS Microbiology Letters, v.100, n.1-2, p.205-210, 1992.

WEINRAUCH, Y.; ZYCHLINSKY, A. The induction of apoptosis by bacterial pathogens. Annual Review of Microbiology, v.53, p.155-187, 1999.

WELLS, J.M.; RAJU, B.C.; HUNG, H.Y. et al. Xylella fastidiosa gen. nov., sp. nov. gram-negative, xylem-limited, fastidious plant bacteria related to Xanthomonas spp. International Journal of Systematic Bacteriology, v.37, n.2, p.136-143, 1987. 
WHITEHEAD, N.A.; BARNARD, A.M.L.; SLATER, H.; SALMOND, G.P.C. Quorum-sensing in Gram-negative bacteria. FEMS Microbiology Reviews, v.25, n.4, p.365-404, 2001.

WHITELEY, M.; LEE, K.M.; GREENBERG, E.P. Identification of genes controlled by quorum sensing in Pseudomonas aeruginosa. Proceedings of National Academic Sciences USA, v.96, n.24, p.13904-13909, 1999.

WILSON, T.J.; BERTRAND, N.; TANG, J.L. et al. The rpfA gene of Xanthomonas campestris pathovar campestris, which is involved in the regulation of pathogenicity factor production, encodes an aconitase. Molecular Microbiology, v.28, n.5, p.961-970, 1998.

YAMADA, Y.; NIHIRA, T. Microbial hormones and microbial chemical ecology. In: BARTON, D.R.H.; NAKANISHI, K. (Ed.). Comprehensive natural products chemistry. Oxford: Elsevier, 1998. v.8. p.377-413.

YISICK, K.L.; MCFALL-NGAI, M.J. An exclusive contract specificity in the Vibrio fischeri-Euprymna scolopes partnership. Journal of Bacteriology, v.182, n.7, p.1779-1787, 2000. 